

\section{Anders organiseren in primair onderwijsteams: een zoektocht naar minder werkdruk en meer werkgeluk}

Dr. Aniek Draaisma (Wageningen Universiteit)

Dr. Nienke Woldman (Wageningen Universiteit)

Dr. Piety Runhaar (Wageningen Universiteit)

Prof. dr. Perry den Brok (Wageningen Universiteit)

Prof. dr. Marianne van Woerkom (Erasmus Universiteit Rotterdam/ Universiteit Tilburg)

i.s.m.

dr. Luce Claessens (Universiteit Utrecht)

Florence Lucas, BSc (Wageningen Universiteit)

Maart 2021

(c) Copyright/All rights reserved: Wageningen University \& Research, Tilburg University

Draaisma, A., Woldman, N., Runhaar., P., Brok, P. den, Woerkom, M. van (2021). Anders organiseren in primair onderwijsteams: een zoektocht naar minder werkdruk en meer werkgeluk. Wageningen: Wageningen University and Research/Tilburg University

Omslagfoto: Pixabay

Subsidie/opdrachtgever: Ministerie van Onderwijs, Cultuur en Wetenschap en het Nationaal Regieorgaan Onderwijsonderzoek (NRO)

ISBN: $978-94-6395-772-4$

DOI: https://doi.org/10.18174/544885 


\section{Inhoudsopgave}

$1 \quad$ Inleiding

$1.1 \quad$ Aanleiding en vraagstelling 6

1.2 Theoretisch uitgangspunten 6

1.2.1 Balans tussen werkdruk en werkgeluk 6

1.2.2 Teambenadering 7

1.2.3 Formele en informele taakdifferentiatie in teams 7

1.2.4 Sterke puntenbenadering 7

1.2.5 Micro-, meso- en macroniveau 8

1.3 Opbouw van het onderzoek 8

2 Literatuurstudie

$2.1 \quad$ Inleiding

2.2 Onderzoeksvragen

2.3 Gehanteerde methode

2.4 Resultaten

2.4.1 Onderwijsassistenten binnen primair onderwijs teams

2.4.2 Taakdifferentiatie binnen primair onderwijsteams

2.5 Conclusie \& Discussie

2.5.1 Samenvatting van belangrijkste bevindingen 17

2.5.2 Theoretische reflectie en suggesties voor vervolgstudies 18

3 Interviewstudie met deskundigen uit de praktijk

3.1 Inleiding, onderzoeksvragen en doel 19

3.2 Gehanteerde methode 19

3.3 Bevindingen 20

3.3.1 Oorzaken van de werkdruk in het onderwijs 20

3.3.2 Mogelijke oplossingen voor de werkdrukproblematiek 22

3.3.3 Belangrijke randvoorwaarden 23

3.4 Conclusie 25

3.4.1 Puntsgewijze samenvatting van de belangrijkste bevindingen 25

3.4.2 Suggesties voor het vervolgonderzoek (hoofdstukken 4 en 5) 26

4 Meervoudige casestudie 27

4.1 Inleiding 27

4.2 Teamgericht HRM als conceptueel kader 27

4.3 Onderzoeksvragen binnen de meervoudige casestudie 28

4.4 Gehanteerde methode 28

4.4.1 Participerende Primair Onderwijsteams 28

4.4.2 Documenten analyse en schoolbezoeken 28

$\begin{array}{lll}4.4 .3 & \text { Opbouw van de resultaten } & 28\end{array}$ 
4.5 Vijf portretten van scholen

$\begin{array}{llr}4.5 .1 & \text { School } 1 & 29\end{array}$

$\begin{array}{lll}4.5 .2 & \text { School } 2 & 31\end{array}$

$\begin{array}{lll}4.5 .3 & \text { School } 3 & 33\end{array}$

$\begin{array}{lll}4.5 .4 & \text { School } 4 & 34\end{array}$

$\begin{array}{lll}4.5 .5 & \text { School } 5 & 36\end{array}$

4.6 Bevindingen op basis van de portretten 37

4.6.1 Hoe worden de rol- en taakverdeling binnen de (sub)teams vormgegeven? 38

4.6.2 Wat is de rol van de onderwijsassistenten binnen de (sub)teams? 38

4.6.3 Op welke manier vinden de processen van werving en selectie voor de (sub)teams plaats? 39

4.6.4 Welke ontwikkelmogelijkheden hebben de leden van de (sub)teams? 39

4.6.5 Hoe worden individuele bijdragen aan het teamresultaat en behaalde
teamresultaten geëvalueerd en gewaardeerd?

4.6.6 Welke mogelijkheden worden gecreëerd voor teams om samen te werken en te werken aan verbeterambities?

4.6.7 In welke mate draagt de manier van teamwerken bij aan: omgaan met het lerarentekort, het reduceren van werkdruk en verzuim, het verhogen van werkgeluk en het gelijk houden of verhogen van de onderwijskwaliteit?

4.6.8 Op welke manier hebben de maatregelen rondom de COVID-19 pandemie effect gehad op de manier waarop er wordt samengewerkt binnen het team?

4.7 Puntsgewijze samenvatting van de belangrijkste bevindingen

$5 \quad$ Vragenlijststudie

5.1 Inleiding

5.2 Onderzoeksvragen binnen de vierde deelstudie: de vragenlijststudie 44

5.3 Methode 45

5.3.1 Participanten $\quad 45$

$\begin{array}{lll}5.3 .2 & \text { Procedure } & 45\end{array}$

$\begin{array}{ll}5.3 .3 & \text { Instrumenten }\end{array}$

$\begin{array}{lll}\text { 5.3.4 Data analyse } & 47\end{array}$

5.4 Bevindingen 47

5.4.1 In welke mate en op welke manier wordt werkdruk, werkgeluk en vertrekintentie ervaren? 47

5.4.2 In welke mate en hoe verschilt de ervaren werkdruk, werkgeluk, vertrekintentie en waargenomen teamgerichte HRM praktijken tussen functiegroepen (leraren, onderwijsassistenten en schoolleiders)?

5.4.3 In welke mate en hoe hangen ervaren werkgeluk, werkdruk en vertrekintentie samen met individuele verschillen tussen teamleden en met de aanwezigheid van op sterke punten gebaseerde teamgerichte HRM praktijken?

5.4.4 Welke verbetermogelijkheden ziet men als het gaat om verlaging van de werkdruk door inzet van onderwijsassistenten en andere vormen van taakdifferentiatie?

5.5 Conclusie

6.1 Terugblik op de deelstudies 53

6.1.1 De inzet van onderwijsassistenten $\quad 53$

6.1.2 Differentiatie binnen teams (anders organiseren) 54

6.2 De bevindingen van de studie samengebracht in een toolkit: de Manometer 54 
Bijlage 1: Teamgericht personeelsbeleid als ordeningskader voor vervolgstudies

Bijlage 2: Topiclijst explorerende interviews

Bijlage 3: Topiclist interviews casestudies

Bijlage 4: Vragenlijst leraren, onderwijsassistenten, schoolleiders

Bijlage 5: Coderingtabel open vragen vragenlijststudie

Bijlage 6: Feedback expertpanel toolkit 


\section{Inleiding}

\subsection{Aanleiding en vraagstelling}

Het primair onderwijs kampt al jaren met een toenemend lerarentekort. De afgelopen jaren zijn dan ook verschillende maatregelen getroffen om dit tekort terug te dringen. Deze maatregelen waren enerzijds gericht op het aantrekken van meer leraren, door bijvoorbeeld verlaging van het collegegeld van de pabo, uitbreiding van de zij-instroomregeling en een subsidieregeling voor herintreders. Anderzijds richtten de maatregelen zich op het behoud van zittende leraren door bijvoorbeeld werkdrukvermindering of salarisverhoging (Rijksoverheid, 2018).

Het hier gerapporteerde onderzoek borduurt voort op eerder genomen initiatieven door in te zoomen op de organisatie van het onderwijs (primair proces). De afgelopen jaren is door scholen namelijk geëxperimenteerd met verschillende manieren van het vormgeven van het onderwijs, waarbij bijvoorbeeld groepsoverstijgend gewerkt werd aan bepaalde thema's. Hoewel aan deze initiatieven vaak andere, namelijk onderwijskundige, motieven ten grondslag lagen, waren er indicaties dat zij ook konden bijdragen aan het terugdringen van het lerarentekort. Alternatieve onderwijsvormen gaan namelijk vaak gepaard met de inzet van extra ondersteunend personeel (zoals onderwijsassistenten of lerarenondersteuners), meer samenwerking en mogelijkheden tot specialisatie, wat de baantevredenheid van leraren ten goede lijkt te komen en verzuim lijkt terug te dringen (Van den Berg, Scheeren \& Arslan, 2017).

De centrale vraag van dit onderzoek is de volgende:

In hoeverre, op welke manier, en onder welke voorwaarden kunnen a) de inzet van onderwijsassistenten en b) taakdifferentiatie binnen teams bijdragen aan het terugdringen van het lerarentekort, reduceren van werkdruk en verzuim, verhogen van arbeidstevredenheid en gelijk houden of verhogen van de onderwijskwaliteit?

Concreet beoogt het onderzoek een antwoord te geven op de volgende vragen:

\section{Thema a) Inzet onderwijsassistenten}

1. Wat is er bekend uit literatuuronderzoek over de effectiviteit van de inzet van onderwijsassistenten?

2. Op welke manieren en in welke mate worden ze in Nederland (vooral) ingezet?

3. Wat is hierin meer of minder succesvol, en welke randvoorwaarden zijn daarbij van belang?

4. Wat zijn de gepercipieerde effecten (onder schoolleiders, leraren, en de assistenten zelf) als het gaat om ondervangen lerarentekorten, verminderen werkdruk, en minimaal gelijk houden of verhogen van de onderwijskwaliteit?

5. Wat kunnen schoolleiders en leraren doen om onderwijsassistenten effectief en optimaal in te zetten?

\section{Thema b) Taakdifferentiatie}

1. Welke vormen van taakdifferentiatie worden gevonden in Nederland en in welke mate komen deze voor?

2. Wat zijn daarin succesfactoren, belemmeringen en faalfactoren, en belangrijke randvoorwaarden?

3. Wat is bekend uit de literatuur over effecten van taakdifferentiatie op onderwijskwaliteit, werkdruk en de vraag naar (meer) leraren?

4. Wat zijn gepercipieerde effecten (door schoolleiders en (teams van) leraren) van taakdifferentiatie?

5. Wat kunnen schoolleiders en leraren doen om effectief en optimaal taken te differentiëren binnen een team?

\subsection{Theoretisch uitgangspunten}

In deze paragraaf worden de belangrijkste uitgangspunten gepresenteerd die aan de basis lagen van het onderzoek.

\subsubsection{Balans tussen werkdruk en werkgeluk}

De ondertitel van het project luidt: 'een zoektocht naar minder werkdruk en meer werkgeluk'. De inzet van ondersteuners zoals onderwijsassistenten en andere vormen van taakdifferentiatie hebben immers tot doel om de werkdruk te verminderen opdat dit het werkgeluk niet ondermijnt. We baseren ons in dit onderzoek op de zogenoemde 
Job-Resources-Job-Demands theorie die veronderstelt dat wanneer de taakeisen (job demands, zoals werkdruk) de hulpbronnen (job resources) overstijgen, dit tot negatieve uitkomsten (zoals werkstress) kan leiden. Omgekeerd, wanneer men het idee heeft over meer dan voldoende hulpbronnen (job resources, zoals collegiale steun) of regelmogelijkheden (zoals participatie in besluitvorming) te beschikken om de taakeisen het hoofd te bieden, dan kan dit juist tot positieve uitkomsten leiden (zoals engagement of werkgeluk). Daarin spelen tevens de psychologische basisbehoeften van sociale verbondenheid (samenwerken, team), ervaren autonomie (job crafting, ruimte en flexibiliteit) en competentiegevoelens (zelfvertrouwen, inzicht in verbeterpunten) een rol (Jansen in de Wal, Van den Beemt, Martens \& Den Brok, 2018). Het is dus de verhouding tussen negatieve en positieve werkkenmerken die bepalend is voor allerlei werkuitkomsten (Hummel, Hooftman \& Schelvis, 2019; Schaufeli \& Taris, 2013).

\subsubsection{Teambenadering}

Het woord 'team' kent meerdere betekenissen. Als we bijvoorbeeld de definitie van Cohen en Bailey (1997) volgen dan wordt een 'echt team' gedefinieerd als een groep individuen die van elkaar afhankelijk zijn bij de uitvoering van hun taken; die gezamenlijk verantwoordelijk zijn voor uitkomsten; die zichzelf zien als een eenheid binnen het grotere geheel en zo ook door anderen worden gezien. In de praktijk wordt echter onder team vaak een hele school of locatie verstaan. Deze teams zijn daarom niet altijd 'echte' teams volgens de bovenstaande omschrijving, maar bestaan op zijn minst uit meerdere sub-teams. Denk bijvoorbeeld aan de leraren van groepen $1 \& 2$ op een basisschool die werkwijzen op elkaar moeten afstemmen en als team verantwoordelijk zijn voor een goede doorstroom naar de vervolggroepen.

Teams hoeven zich niet te beperken tot het personeel behorende bij een school. Ook externe actoren (ouders, medewerkers van de kinderopvang bijvoorbeeld) kunnen tot het team gerekend worden. We spreken dan van 'extended teams' (Nieuwenhuis, 2013). De verscheidenheid in de percepties van wat als een team wordt beschouwd, zien wij als een verrijking van ons onderzoek.

\subsubsection{Formele en informele taakdifferentiatie in teams}

Taakdifferentiatie kan zich op een formele manier uiten doordat taken of rollen worden toegewezen aan specifieke functionarissen (onderwijsassistent of leraar bijvoorbeeld) omdat deze geassocieerd worden met functieschalen. Hoe breder de impact van een rol binnen een team (bijvoorbeeld de rol van innovator of begeleider van startende leraren) hoe hoger de schaal. Het 'career framework university teaching' (Graham, 2018), waarin promotiecriteria beschreven staan voor universitair docenten, kan in dit licht inspiratie bieden. Op informele manier kunnen teamleden hun werk echter ook op zo'n manier inrichten dat dit aan hun individuele behoeften voldoet. We spreken dan van 'job craften' (of team craften, zie Leana, Appelbaum, \& Shevchuk, 2009). Met job crafting wordt gedoeld op de variaties die leraren kunnen aanbrengen in hun werk zodat zij meer het gevoel hebben 'in control' te zijn en minder werkdruk ervaren (Van Wingerden, Bakker, \& Derks, 2017). Te denken valt aan invallen voor elkaar om ruimte voor de ander te creëren; zelf samenwerkingspartners bepalen; werktijd voor een deel zelf kunnen indelen, etc. Zo wordt in het kader van de balans tussen job demands en job resources meer zwaarte aan de resource kant gecreëerd.

Om vernieuwende inzichten te bieden voor PO-scholen, kijken we naast taakdifferentiatie ook naar roldifferentiatie gericht op rollen die vervuld dienen te worden. Het voordeel van een gerichtheid op rollen is dat de daaruit voorvloeiende taken meer op elkaar aansluiten, met een minder gefragmenteerd takenpakket als gevolg. We bouwen voort op inzichten uit het mbo/hbo (zie bijvoorbeeld Oonk, Beers, \& Wesselink, 2013) door na te gaan welke verschillende rollen binnen een PO-team vervuld moeten en kunnen worden, en voorts bij wie die rollen passen. Zijn dat bijvoorbeeld onderwijsassistenten? Of meer ervaren leraren?

\subsubsection{Sterke puntenbenadering}

De sterke puntenbenadering is gestoeld op de positieve psychologie (zie Van Woerkom, 2018). In lijn hiermee gaan we ervan uit dat wanneer mensen die rollen op zich nemen die passen bij hun sterke punten, zij hier meer energie van zullen krijgen en meer gemotiveerd zullen zijn dan wanneer zij taken toebedeeld krijgen op basis van, bijvoorbeeld, anciënniteit, gewoonte of beschikbare uren. Mensen verschillen van elkaar in waar zij goed in zijn, zo ook in teams. Om tot een optimaal teamresultaat te komen, is het zinvol om na te gaan hoe ieders unieke kwaliteit zo goed mogelijk benut kan worden. 


\subsubsection{Micro-, meso- en macroniveau}

Het vraagstuk rond 'anders organiseren' speelt op meerdere niveaus: binnen scholen vraagt het om aanpassingen van individuele leraren en lerarenteams, maar het raakt ook het schoolbrede beleid. Er zal dan ook gekeken worden naar inbedding van vormen van anders organiseren in het HRM beleid, waarbij HRM (Human Resources Management) verwijst naar het geheel van beleid en praktijken die gericht zijn op het aantrekken, behouden, ontwikkelen en belonen van leraren op zo'n manier dat het de leraar-, team- en schoolprestaties verhoogt (Runhaar, 2017).

Scholen maken op hun beurt vaak deel uit van een bestuur, die weer opereert in een sector, die weer deel uitmaakt van de Nederlandse maatschappij, waar meerdere actoren zich bezighouden met het lerarentekort. Voorbeelden van die actoren zijn lerarenopleidingen (die verschillende teamleden aanleveren variërend van onderwijsassistenten tot academisch geschoolde leraren); de PO-Raad en de Aob. We zullen de bredere context waarin teams opereren dan ook expliciet betrekken in ons onderzoek.

\subsection{Opbouw van het onderzoek}

Het onderzoek is opgebouwd uit een viertal deelstudies. Over deze deelstudies zijn ook deelrapportages en nieuwsberichten verschenen - onder meer via de website van de Wageningen Universiteit - welke in deze eindrapportage zijn samengevoegd.

Het onderzoek startte met een literatuurstudie, waarin zowel praktische als wetenschappelijke literatuur op het vlak van anders organiseren in onderwijsteams als de inzet van onderwijsassistenten is verzameld en geanalyseerd. Over dit literatuuronderzoek doen wij in hoofdstuk 2 verslag. De tweede stap van het onderzoek bestond uit het verzamelen van informatie vanuit het veld, om zo de bestaande situatie rondom anders organiseren en de inzet van onderwijsassistenten in kaart te brengen. Deze informatie is verzameld bij een diversiteit aan experts, via semigestructureerde interviews. Over dit deelonderzoek wordt in hoofdstuk 3 verslag gedaan, waarbij gekeken wordt naar de mate waarin de uitkomsten overeenstemmen met het literatuuronderzoek, maar ook naar de aanvullende inzichten die de praktijk oplevert. In een derde deelstudie zijn vijf scholen die hun onderwijs anders hebben georganiseerd in de diepte geanalyseerd. Deze meervoudige casestudie wordt beschreven in hoofdstuk 4. De bevindingen uit de literatuurstudie, de interviewstudie en de meervoudige casestudie zijn vervolgens omgezet in een vragenlijst voor drie typen respondenten: leraren, onderwijsassistenten en schoolleiders. Bij een grotere groep respondenten is gekeken naar de relaties tussen de organisatie van het onderwijs, inzet van onderwijsassistenten, en zaken als werkdruk en werkgeluk. Deze deelstudie wordt gerapporteerd in hoofdstuk 5. Dit rapport sluit af in hoofdstuk 6 met een terugblik op de deelstudies en de aankondiging van een toolkit voor scholen, die is gebaseerd op de bevindingen uit de diverse onderzoeken. 


\section{Literatuurstudie}

\subsection{Inleiding}

Het primair onderwijs kampt al jaren met een toenemend lerarentekort en daaraan gekoppeld een toenemende werkdruk. De afgelopen jaren zijn dan ook verschillende maatregelen getroffen om scholen te helpen in het omgaan met het groeiend lerarentekort. Deze maatregelen focussen enerzijds op het aantrekken van meer leraren, door bijvoorbeeld verlaging van het collegegeld van de pabo, uitbreiding van de zij-instroomregeling en een subsidieregeling voor herintreders. Anderzijds richten de maatregelen zich op het behoud van zittende leraren door bijvoorbeeld werkdrukvermindering of salarisverhoging (Rijksoverheid, 2018).

De afgelopen jaren is door scholen geëxperimenteerd met verschillende manieren van het organiseren van het onderwijs, zoals groepsoverstijgend werken. Hoewel aan deze initiatieven vaak onderwijskundige motieven ten grondslag liggen, zijn er indicaties dat deze ook kunnen bijdragen aan het effectief omgaan met het lerarentekort. Alternatieve onderwijsvormen gaan namelijk vaak gepaard met de inzet van extra ondersteunend personeel (zoals onderwijsassistenten of lerarenondersteuners), meer samenwerking en specialisatie, wat de baantevredenheid van leraren ten goede lijkt te komen en verzuim lijkt terug te dringen (Van den Berg, Scheeren \& Arslan, 2017).

In het algemeen kan worden gesteld dat tussen 2005 en 2017 de taakeisen in alle sectoren van het onderwijs zijn toegenomen - zowel in termen van de context waarin het werk gedaan wordt (denk aan toegenomen onzekerheid m.b.t. rollen, taken en arbeidscontracten) als in termen van de taakinhoud (zoals de emotionele belasting van het werk, tijdsdruk en hoeveelheid van het werk). Tegelijkertijd is de regelruimte - bijvoorbeeld in termen van autonomie, inspraak en functionele steun van leidinggevende en collega's - juist afgenomen. De disbalans die hierdoor ontstaan is, leidt steeds vaker tot werkstress en zelfs burn-out. Deze disbalans is door een snelle toename in taakeisen vooral in het primair onderwijs terug te vinden (Hummel, Hooftman \& Schelvis, 2019).

Medewerkers in het onderwijs ervaren een hogere werkdruk dan medewerkers in andere sectoren, en dat geldt in het bijzonder voor het primair onderwijs (zie bijv. Adriaens, Van Grinsven, Van der Woud \& Westerik, 2016; Hummel et al., 2019; Van Grinsven, Elphick \& Van der Woud, 2012). De toegenomen werkdruk wordt door leraren vooral gelinkt aan hun brede takenpakket met veel niet-lesgebonden taken en de registratie en administratie rondom zorgleerlingen. Leraren geven bovendien aan dat zij de werkdrukproblemen vooral in eigen tijd oplossen (Backbier, Frielink \& Groeneveld, 2001; Houtman \& Stege, 2015). Leraren met een groot parttime contract die vaak overwerken zijn dan ook een belangrijke risicogroep als het gaat om werkstress en burn-out (Hummel et al., 2019). Hoewel leraren in het primair onderwijs in vergelijking met andere onderwijssectoren meer steun ervaren van hun leidinggevenden en minder ongewenst gedrag van leerlingen, worden zij in vergelijking met andere onderwijssectoren wel vaker geconfronteerd met ongewenst gedrag van ouders of verzorgers (Hummel et al., 2019).

Op dit moment krijgt het grootste deel van de basisscholen (98 procent) nog steeds een voldoende van de Onderwijsinspectie en is het aandeel scholen dat (zeer) zwak beoordeeld wordt de laatste jaren afgenomen (Onderwijsraad, 2018). Door het toenemende lerarentekort, niet alleen in Nederland maar ook in de landen om ons heen (OESO, 2019), en toenemende stress en burn-out symptomen kan de kwaliteit van het onderwijs echter wel onder druk komen te staan. De kwaliteit van het onderwijs wordt immers voor een groot deel bepaald door de kwaliteit van de leraren (Creemers \& Kyriakides, 2015). Het is dan ook niet verwonderlijk dat de Nederlandse overheid meer zicht wil krijgen op factoren die bijdragen aan werkdrukreductie van leraren ${ }^{1}$.

\footnotetext{
${ }^{1}$ Zie bijvoorbeeld de kamerbrief Ruimte voor regie in het primair onderwijs, van minister Slob: https://www.rijksoverheid.nl/documenten/kamerstukken/2019/06/11/kamerbrief-ruimte-voor-regie-in-het-primair-onderwijs
} 


\subsection{Onderzoeksvragen}

De literatuurstudie beoogt een antwoord te geven op de volgende vragen, die zijn afgeleid van de onderzoeksvragen die in hoofdstuk 1 zijn geformuleerd:

1. Wat is er bekend over de inzet van onderwijsassistenten en taakdifferentiatie binnen teams?

2. Wat zijn de effecten van onderwijsassistenten en taakdifferentiatie op de onderwijskwaliteit, werkdruk/verzuim, werktevredenheid en de vraag naar nieuwe leraren?

3. Wat zijn de randvoorwaarden waarbinnen deze effecten optreden?

4. Wat kunnen schoolleiders en leraren doen om effectief onderwijsassistenten in te zetten en taken te differentiëren binnen teams?

\subsection{Gehanteerde methode}

De literatuurstudie is gestart met het zoeken in de wetenschappelijke database Web of Science. Voor de onderwerpen 'taakdifferentiatie' en 'de inzet van onderwijsassistent' zijn twee sets van specifieke zoektermen gebruikt ${ }^{2}$ die voor beide onderwerpen een ander resultaat opleverden:

$>$ met betrekking tot de inzet van onderwijsassistenten in het primair onderwijs vonden we vijf wetenschappelijke publicaties. Deze waren vooral afkomstig uit het Verenigd Koninkrijk, waar rond de eeuwwisseling veel aandacht was voor de inzet van onderwijsassistenten (zie bijvoorbeeld Bach, Kessler \& Heron, 2006).

> Over taakdifferentiatie in primair onderwijs werden geen wetenschappelijke publicaties gevonden.

Voorts is gezocht naar relevante 'grijze' literatuur (d.w.z. praktijk- of beleidsgerichte onderzoeksrapporten) via Google en Google Scholar. Voor onderwijsassistenten leverde dit rapporten op zoals die van ResearchNed (Kurver \& Driessen, 2018) en van de Education Endowment Foundation (Sharples, Blatchford, \& Webster, 2018). Hoewel de term taakdifferentiatie niet altijd expliciet wordt genoemd, is de afgelopen decennia wel veel praktijkgericht- en beleidsonderzoek gedaan naar de rol en taakverdeling binnen primair onderwijs teams en de effecten op werkdruk en onderwijskwaliteit (zie bijvoorbeeld Boogaard, Blok, Van Eck, \& Schoonenboom, 2004). Zodoende vonden we niet alleen beleidsonderzoeksrapporten (van, bijvoorbeeld, het CAOP) maar ook Nederlandstalig (semi) wetenschappelijke rapportages, zoals die van Imants (1996) en Snoek en Volman (2014). Daarnaast leverden onderzoeken op het gebied van 'teacher collaboration' (Meirink, Imants, Meijer \& Verloop, 2010) en 'team learning in vocational education' (Bouwmans, Runhaar, Wesselink \& Mulder, 2017) relevante informatie op.

Alle in de resultaten besproken documenten zijn in de referentielijst met een Asterisk aangemerkt. In onderstaande tabel staan de belangrijkste begrippen die zijn gebruikt in de literatuurstudie.

\section{Uitleg van de belangrijkste begrippen uit de literatuurstudie}

Onderwijsassistenten $=$ Onderwijsassistenten ondersteunen leraren in het primair, voortgezet of beroepsonderwijs. Takenpakketten verschillen per school en worden in overleg met de leraar bepaald. Onderwijsassistenten hebben een diploma behaald van de opleiding tot onderwijsassistent (mbo niveau 4) of de specialisatie tot onderwijsassistent binnen de opleiding Sociaal Pedagogisch Werk (mbo niveau 3).

Lerarenondersteuners $=$ Een lerarenondersteunersfunctie zit tussen een onderwijsassistent en een leraar in, met als belangrijkste verschil dat een lerarenondersteuner zelfstandig taken mag uitvoeren zoals lesgeven en toetsen nakijken. De opleiding tot lerarenondersteuner is een associate degree opleiding: een tweejarige, praktijkgerichte opleiding die qua niveau tussen mbo en hbobachelor in zit.

\footnotetext{
2 Voor taakdifferentiatie werd de volgende set zoektermen gebruikt: TOPIC: "task differentiation" OR "team collaboration" OR "shared responsibilit*" OR "teacher team*" OR "co-teaching") AND TOPIC: ("primary education" OR "secondary education" OR "higher education" OR "vocational education" OR "education"). " refined by: DOCUMENT TYPES: (ARTICLE OR REVIEW OR PROCEEDINGS PAPER). Voor onderwijsassistenten de volgende set: TOPIC: ("teach* assistants") AND TOPIC: (workload OR work stress).
} 
$\begin{array}{ll}\text { Functiedifferentiatie }= & \begin{array}{l}\text { De verschillende onderwijsgevende en onderwijsondersteunende functies die in het } \\ \text { onderwijs bestaan. }\end{array}\end{array}$

Taakdifferentiatie $=\quad$ Mensen in eenzelfde functie kunnen een verschillend takenpakket krijgen toebedeeld.

Teamgericht

Personeelsbeleid gericht op samenwerken en leren binnen lerarenteams.

personeelsbeleid $=$

\subsection{Resultaten}

Hieronder worden de resultaten met betrekking tot de inzet van onderwijsassistenten en taakdifferentiatie in twee aparte paragrafen beschreven. De twee paragrafen zijn voorts gestructureerd op basis van de onderzoeksvragen. Telkens wordt eerst ingegaan op wat bekend is over de inzet van onderwijsassistenten dan wel taakdifferentiatie, over de effecten ervan op onderwijskwaliteit, werkdruk/verzuim, werktevredenheid en de vraag naar nieuwe leraren, over de randvoorwaarden waarbinnen die effecten optreden en over datgene wat schoolleiders en leraren kunnen doen ten behoeve van effectieve inzet.

\subsubsection{Onderwijsassistenten binnen primair onderwijs teams}

De afgelopen jaren heeft het kabinet extra geïnvesteerd in het reduceren van de werkdruk in het primair onderwijs. Dienst Uitvoering Onderwijs (DUO) Onderwijsonderzoek \& Advies (2019) heeft gepeild hoe deze zogenoemde 'werkdrukmiddelen' de afgelopen jaren zijn besteed en komt tot de conclusie dat in 2018-2019, de extra middelen voornamelijk werden gebruikt voor de inzet van onderwijsassistenten. De verwachting is dat dit in 2019-2020 niet zal veranderen.

Researchned heeft in opdracht van het Ministerie van OCW recent onderzoek gedaan naar de inzet van onderwijsassistenten in Nederland (Kurver \& Driessen, 2018). Sinds 2004 hebben 40.000 onderwijsassistenten hun opleiding afgerond. Het aantal afgestudeerden neemt gestaag af van 4.000 in 2005/2006 naar ongeveer 2.600 in 2015/2016 (een afname van 35\%). Van de afgestudeerde onderwijsassistenten heeft $83 \%$ een betaalde baan gevonden. Van die groep is ruim een derde werkzaam in het onderwijs en dan met name in het primair onderwijs $(27 \%$ van de werkende alumni). Een groot deel van deze afgestudeerde onderwijsassistenten studeert verder (22\%) of heeft al een vervolgopleiding afgerond $(31 \%)$, wat in de helft van de gevallen een lerarenopleiding betreft.

\section{Wat is bekend over de inzet van onderwijsassistenten?}

Uit het rapport van Researchned (Kurver \& Driessen, 2018) valt op te maken dat de gemiddelde omvang van de vaste aanstelling van onderwijsassistenten $0.7 \mathrm{fte}$ is en die van een tijdelijke aanstelling $0.6 \mathrm{fte}$. Onderwijsassistenten met een vaste aanstelling verdelen hun werk over drie à vier dagen en zij met een tijdelijke aanstelling over twee of drie dagen. Het merendeel van de onderwijsassistenten (65\%) wordt betaald in schaal 4 . Onderwijsassistenten houden zich het meest bezig met het ondersteunen en begeleiden van leerlingen (93\%), met extra begeleiding voor kinderen met een achterstand $(85 \%)$ en surveillance- of pleinwachttaken $(75 \%)$. De begeleiding van leerlingen gebeurt meestal in kleine groepjes in of buiten de klas (Kurver \& Driessen, 2018).

Het onderzoek van Researchned (Kurver \& Driessen, 2018) laat tevens zien dat onderwijsassistenten veel minder vaak bezig zijn met het schrijven van handelingsplannen $(7 \%)$, het verzorgen van huiswerkbegeleiding $(8 \%)$ en het invullen van rapporten (10\%). Toch blijkt een aanzienlijk aandeel van de onderwijsassistenten zich vaak bezig te houden met taken die lijken op de taken van een leraar: ruim een kwart (26\%) van de onderwijsassistenten geeft aan geregeld zelfstandig les te geven (dit is formeel niet toegestaan) en 45 procent neemt de klas waar bij afwezigheid van een leraar, waarbij niet duidelijk is of deze twee taken onder toezicht van een leraar gedaan worden (Kurver \& Driessen, 2018). Tot slot wordt opgemerkt dat de inzet van onderwijsassistenten in primair en speciaal onderwijs verschilt; waar onderwijsassistenten in het basisonderwijs met name worden ingezet bij het begeleiden van kleine groepjes leerlingen buiten de klas, geven onderwijsassistenten binnen het speciaal onderwijs met name begeleiding aan kleine groepjes leerlingen in de klas en geven onderwijsassistenten in het basisonderwijs vaker individuele begeleiding dan hun collega's in het speciaal onderwijs (Kurver \& Driessen, 2018). 


\section{Wat is bekend over de effecten van de inzet van onderwijsassistenten op onderwijskwaliteit, werkdruk/verzuim, werktevredenheid en de vraag naar nieuwe leraren?}

Onderzoek naar de effecten van de inzet van onderwijsassistenten in Nederland is schaars. Kwantitatieve onderzoeken naar effecten van onderwijsassistenten op onderwijskwaliteit, werkdruk/verzuim, werktevredenheid en de vraag naar nieuwe leraren in Nederland, zijn we niet tegengekomen. Wel vonden we kwalitatieve onderzoeken naar de inzet van onderwijsassistenten. Deze richten zich vooral op werkdruk van leraren en baantevredenheid van onderwijsassistenten. Omdat in het Verenigd Koninkrijk wel veel onderzoek gedaan is naar de inzet van 'teaching assistants' (zie Kennisrotonde, $2019^{3}$ ), zal hieronder daar waar relevant verwezen worden naar uitkomsten van onderzoek uit het Verenigd Koninkrijk.

Hoewel wij dus geen 'harde cijfers' over de effecten van de inzet van onderwijsassistenten zijn tegengekomen, suggereren de door ons geraadpleegde bronnen dat de inzet van onderwijsassistenten positieve effecten heeft op de werkdruk in scholen en op tevredenheid van de assistenten zelf. Uit het onderzoek van DUO Onderwijsonderzoek \& Advies (2019) komt bijvoorbeeld naar voren dat volgens $88 \%$ van de bij het onderzoek betrokken bestuurders, de inzet van onderwijsassistenten de ervaren werkdruk door leraren vermindert. Het lijkt er volgens respondenten zelfs op dat alleen al de extra aandacht vanuit de overheid voor werkdruk dit positieve effect verklaart (DUO Onderwijsonderzoek \& Advies, 2019). Ook in het Verenigd Koninkrijk bleek dat de inzet van onderwijsassistenten ruimte creëerde voor leraren om te reflecteren op hun eigen lespraktijk, en de ontwikkeling van leerlingen in kaart te brengen (Galton \& MacBeath, 2010). Zonder dat het resulteerde in minder uren werk, gaf de inzet van onderwijsassistenten leraren de mogelijkheid om met collega's samen te werken en adviezen uit te wisselen, en gaf het hen het gevoel op waarde geschat te worden (ibid).

De baantevredenheid van onderwijsassistenten zelf blijkt behoorlijk hoog: ruim $60 \%$ van de onderwijsassistenten is (zeer) tevreden over de taakverdeling met leraren en ongeveer de helft van de onderwijsassistenten is (zeer) tevreden over het takenpakket. Slechts een kleine groep onderwijsassistenten is over deze aspecten (zeer) ontevreden (respectievelijk 10\% en 15\%, Kurver \& Driessen, 2018). Als het gaat om de werkomstandigheden, dan blijken onderwijsassistenten het meest tevreden te zijn over de samenwerking binnen het team, de mate van zelfstandigheid en over hun werkplek (bijna $70 \%$ is positief over deze aspecten). Ruim $60 \%$ van de onderwijsassistenten is echter ontevreden over het salaris. Ook over de werkdruk en de mogelijkheden tot persoonlijke ontwikkeling is ruim $30 \%$ van de onderwijsassistenten ontevreden (Kurver \& Driessen, 2018). Bijna 60\% van de onderwijsassistent geeft overigens wel aan dat hun wensen met betrekking tot loopbaanontwikkeling besproken worden in functionerings- of ontwikkelgesprekken met leidinggevenden. Kennelijk worden de mogelijkheden om door te groeien als beperkt ervaren (Kurver \& Driessen, 2018).

De inzet van onderwijsassistenten kan ook indirect een positief effect hebben op de vermindering van het lerarentekort. Zo laten Kurver en Driessen (2018) zien dat van de afgestudeerde onderwijsassistenten in 2015/2016 23\% doorstroomt naar de pabo. Deze doorstroom is de laatste jaren relatief lager vanwege de toelatingseisen voor vakken als aardrijkskunde, geschiedenis, natuur en techniek die per 2014-2015 zijn ingevoerd. Deze eisen hebben vooral mensen met een mbo of havo diploma van de pabo geweerd (de instroom van deze groepen was 50\%-punt respectievelijk 20\%-punt lager dan voor de invoering van de eisen, Bolhaar \& Van Ruijven, 2019). Kurver en Driessen (2018) schatten voorts in dat de bereidheid van onderwijsassistenten om door te stromen naar de pabo met $42 \%$-punt stijgt als er geen collegegeld hoeft te worden betaald en men acht uur betaald studieverlof zou krijgen van de werkgever. Om in deze bereidheid te voorzien bestaat een subsidieregeling, waar in 2019328 aanvragen voor zijn gedaan ${ }^{4}$. Ook blijkt dat $37 \%$ van de werkende onderwijsassistenten de wens heeft om zich te professionaliseren tot lerarenondersteuner middels een associate degree opleiding (Kurver \& Driessen, 2018).

\section{Onder welke voorwaarden treden de positieve effecten op?}

Uit de literatuur komt een aantal randvoorwaarden naar voren voor een effectieve inzet van onderwijsassistenten. Hiervan is rolduidelijkheid de meest genoemde randvoorwaarde, zowel voor wat betreft het primair onderwijs in Nederland (zie bijvoorbeeld Kurver \& Driessen, 2018) en het Verenigd Koninkrijk (Bach et al., 2006; Galton \&

3 De Endowment Foundation heeft veel onderzoek uit het Verenigd Koninkrijk vertaald in praktische tools en adviezen. Omdat deze vrij context specifiek zijn, voert het te ver deze hier te benoemen. Deze zijn te vinden via: http://educationendowmentfoundation.org.uk/tools/guidancereports/making-best-use-of-teaching-assistants/

4 https://www.dus-i.nl/subsidies/onderwijsassistenten-naar-opleiding-tot-leraar 
MacBeath, 2010) als in het wetenschappelijk onderwijs (De Putter \& Den Brok, 2015). Onderzoek naar de inzet van onderwijsassistenten in het VK laat zien dat onderwijsassistenten vooral lesgevende en begeleidingstaken op zich nemen zodat leraren meer tijd hebben om bijvoorbeeld hun lessen voor te bereiden. Duidelijkheid over het exacte takenpakket, de hoeveelheid beschikbare tijd die daarvoor staat en de afstemming met de taken van leraren bepaalt in sterke mate de ervaren werkdruk en het werkgeluk van zowel leraar als onderwijsassistent (bijv. Bach et al., 2006). Een goede voorbereiding van onderwijsassistenten wordt dan ook niet voor niets als succesfactor genoemd. Een goede opleiding en voldoende contact en overleg met leraren is bijvoorbeeld van belang (Sharples et al., 2018), maar ook ondersteuning tijdens de taakuitvoering wanneer onderwijsassistenten bijvoorbeeld met problemen of dilemma's geconfronteerd worden en mogelijkheden tot verdere professionalisering (Ryall \& Goddard, 2003). Rolstress, vanwege onduidelijkheid of tegengestelde verwachtingen wordt al langer in verband gebracht met allerlei negatieve uitkomsten zoals burnoutklachten (zie, bijvoorbeeld, Örtqvist \& Wincent, 2006). Het is dus van belang om ervoor te zorgen dat rolduidelijkheid en voorbereiding of training van onderwijsassistenten goed op orde zijn.

Wat raakt aan rolduidelijkheid en goede voorbereiding is een duidelijke visie van de schoolleiding op de inzet van onderwijsassistenten. Bach en collega's (2006) bevelen schoolleiders aan om een lange termijnvisie te ontwikkelen op een structurele inzet van onderwijsassistenten. Door onderwijsassistenten bijvoorbeeld een duidelijke rol in het curriculum te geven ontstaat voor hen de mogelijkheid een specialisme te ontwikkelen (bijvoorbeeld binnen een vak) dat duidelijk herkenbaar is binnen een team. Hierdoor worden onderwijsassistenten ook echt als onderdeel van het team beschouwd (Ryall \& Goddard, 2003). Net als Kurver en Driessen (2018) zetten Bach en anderen (2006) in op de structurele inzet van onderwijsassistenten in plaats van een korte-termijn- en pragmatische inzet. Sharples en collega's (2018) voegen eraan toe oog te hebben voor verbindingen tussen de taken van onderwijsassistenten buiten de klas en datgene wat binnen de klas plaatsvindt. Hierbij dient altijd helder geformuleerd te zijn wat hun toegevoegde waarde is. Ze dienen niet ingezet te worden als privéleraar voor onderpresterende leerlingen.

Naast rolduidelijkheid bevelen De Putter en Den Brok (2015) aan dat er voldoende tijd moet zijn voor onderwijsassistenten om ook onderling af te stemmen hoe zij hun rol en taken invullen en dat zij, net als leraren, toegang dienen te hebben tot praktische faciliteiten (bijvoorbeeld een kopieerpasje en toegang tot administratieve systemen). Aanvullend hierop dienen onderwijsassistenten toegang te hebben tot informatie die relevant is voor de taakuitvoering, zoals beleidstukken, protocollen en leerlinggegevens (Ryall \& Goddard, 2003).

\section{Wat kunnen schoolleiders en leraren doen om effectief onderwijsassistenten in te zetten?}

Op basis van de vorige twee paragrafen komen we tot de volgende aanbevelingen voor schoolleiders:

Blijf onderwijsassistenten inzetten aangezien zij de werkdruk binnen lerarenteams kunnen verminderen;

Zorg voor een duidelijke visie op de rol van onderwijsassistenten in het curriculum en binnen het schoolteam;

Faciliteer de roluitvoering van onderwijsassistenten in ruimte, tijd en middelen maar ook in

professionaliseringsmogelijkheden;

Faciliteer een duidelijke afstemming tussen onderwijsassistenten en leraren over hun onderlinge taakverdeling;

Evalueer regelmatig de tevredenheid van onderwijsassistenten over hun werk;

Luister goed naar de ontwikkelwensen van onderwijsassistenten en faciliteer deze waar mogelijk;

Stimuleer niet alleen doorstoom naar de pabo, maar ook naar associate degree opleidingen, om diversiteit in onderwijsteams aan te moedigen en loopbaanpaden te formuleren;

) Maak duidelijk hoe onderwijsassistenten sneller door kunnen groeien naar hogere schalen. Gebruik hiervoor de voorbeeldfunctieomschrijvingen die als bijlage bij de nieuwe cao primair onderwijs zijn verschenen (https://www.poraad.nl/themas/werkgeverszaken/cao-primair-onderwijs).

Voor leraren komen we tot de volgende aanbeveling:

> Voer regelmatig overleg met onderwijsassistenten over de onderlinge taakverdeling en probeer tegengestelde verwachtingen te voorkomen dan wel op te lossen. 
- Onderwijsassistenten houden zich het meest bezig met het ondersteunen en begeleiden van leerlingen (93\%), met extra begeleiding voor kinderen met een achterstand (85\%) en surveillance- of pleinwachttaken (75\%).

- De inzet van onderwijsassistenten vermindert de ervaren werkdruk van leraren.

- Randvoorwaarden voor deze positieve consequenties zijn:

Rolduidelijkheid en duidelijkheid over de toegevoegde waarde van onderwijsassistenten

Duidelijke visie van de schoolleiding op de inzet van onderwijsassistenten

Een goede voorbereiding van onderwijsassistenten

Ondersteuning tijdens de taakuitvoering

Mogelijkheden tot verdere professionalisering

Toegang onderwijsassistenten tot praktische faciliteiten en informatie

\subsubsection{Taakdifferentiatie binnen primair onderwijsteams}

Zoals gezegd leverde het literatuuronderzoek geen wetenschappelijke artikelen op over taakdifferentiatie in het primair onderwijs. Wel vonden we veel 'grijze' literatuur over aanpalende onderwerpen zoals rol- en taakverdeling en inzet van academische leraren. Deze paragraaf bevat dan ook nauwelijks 'harde cijfers' maar meer kwalitatieve bevindingen over vormen van differentiatie, effecten en randvoorwaarden. Zo voerden onderzoekers van het Kohnstamm Instituut in opdracht van de Onderwijsraad in 2004 een vergelijkbaar onderzoek uit als het onderhavige onderzoek, namelijk een studie naar de effecten van alternatieve organisatievormen binnen het primair onderwijs op de inzet van leraren (Boogaard et al., 2004).

\section{Wat is er bekend over de inzet van taakdifferentiatie?}

In de studie van Boogaard en collega's (2004) wordt een onderscheid gemaakt tussen taakdifferentiatie enerzijds - wat betekent dat leraren in eenzelfde functie een verschillend takenpakket krijgen toebedeeld - en functiedifferentiatie anderzijds - wat betekent dat er verschillende onderwijsgevende en onderwijsondersteunende functies in het onderwijs bestaan zoals leraren, onderwijsassistenten en lerarenondersteuners. Dit onderscheid is in het licht van de toenemende functiedifferentiatie in het onderwijs (zie bijvoorbeeld het Convenant Actieplan Leerkracht van Nederland uit 2008 of de recent hernieuwde cao van primair onderwijs) en in het licht van de centrale vraagstelling van de literatuurstudie zeer relevant. Vandaar dat hieronder op beide vormen van differentiatie ingegaan wordt.

Taakdifferentiatie vindt bijvoorbeeld plaats in 'team teaching': dit is een onderwijsvorm waarbij leerlingen les krijgen van een team van leraren. Dit team kan op verschillende manieren vormgegeven worden. Zo kan de ene leraar bijvoorbeeld instructie geven, terwijl de ander de voortgang monitort, of kunnen bepaalde vakken zoals muziek of geschiedenis verdeeld worden over leraren (zie voor meer informatie Goetz, 2000). Taakdifferentiatie biedt leraren de mogelijkheid om zich te specialiseren in een bepaalde lesinhoud (Van den Heuvel-Panhuizen \& De Goeij, 2005) of activiteit in het onderwijsleerproces (zoals instrueren, coachen, trainen, adviseren en toetsen; Boogaard et al., 2004). Dit is van belang omdat de eisen die de samenleving stelt aan het onderwijs toenemen en niet verwacht kan worden dat elke leraar over alle onderwerpen evenveel expertise ontwikkelt (Van den Heuvel-Panhuizen \& De Goeij, 2005). Specialisatie kan op die manier tot een efficiënter taakverdeling leiden: doordat mensen die taken op zich nemen die zij goed beheersen, kost de voorbereiding ervan bijv. minder tijd.

De mogelijkheden tot functiedifferentiatie zijn met de invoering van meer onderwijsondersteunende functies zoals onderwijsassistenten en lerarenondersteuners sterk toegenomen (OCW, 2003), maar ook met de meer recente invoering van de functie van 'academische leraar' (zie bijvoorbeeld Snoek \& Volman, 2014). Voordeel ook hier weer is de mogelijkheid tot specialisatie (Baar, 2018), niet alleen voor leraren, maar ook voor andere functionarissen. Tevens wordt men in de uitvoering van onderwijs minder afhankelijk van de - schaarser wordende - leraren. Er ontstaan immers meer loopbaanpaden door al deze initiatieven (Broeks, Bakker, Hertogh, Van Meeuwen-Kok, \& Grondwe, 2018). 
Tegenwoordig komen we veelal combinaties van taak- en functiedifferentiatie tegen. Denk bijvoorbeeld aan unitonderwijs, waarin leraren samen met onderwijsondersteunend personeel samenwerken aan onderwijs voor een grote groep leerlingen (Van den Berg et al., 2017) $)^{5}$. Ook zien we dat leerlingen in het primair onderwijs niet alleen te maken hebben met leraren of onderwijsondersteunend personeel dat in dienst is van de school. Denk bijvoorbeeld aan ouders die groepjes leerlingen begeleiden bij lezen of fungeren als overblijfouder. Of denk aan medewerkers van de kinderopvang die de voorschoolse opvang in de school verzorgen of zorgprofessionals die worden ingeschakeld (Bates, Mellin, Paluta, Anderson-Butcher, Vogeler, \& Sterling, 2019). Teams binnen het primair onderwijs hebben dan ook vaak het karakter van 'extended teams' (Nieuwenhuis, 2013) waarmee wordt bedoeld dat onderwijsteams zich kunnen uitstrekken over de grenzen van de schoolorganisatie heen. Ook binnen het mbo is sprake van extended onderwijsteams waarin functionarissen binnen de mbo instellingen (zoals instructeurs, avo en beroepsgerichte docenten) samenwerken met mensen uit de beroepspraktijk (zoals werkplekbegeleiders). Binnen de mbo context is onderzoek gedaan naar de verschillende rollen die binnen het onderwijsleerproces vervuld dienen te worden, zoals assessor of curriculumvernieuwer. Deze rollen zijn vervolgens gekoppeld aan kerntaken en benodigde competenties (Oonk et al., 2013). Als de rollen duidelijk zijn, kan worden nagedacht over welke functionaris deze het beste op zich kan nemen waarbij niet alleen rekening gehouden hoeft te worden met expertise maar ook met affiniteit of loopbaanwensen. Het voordeel van dit soort 'roldifferentiatie' is dat de daaruit voorvloeiende taken op elkaar aansluiten, met een minder gefragmenteerd takenpakket als gevolg dan wanneer vanuit losse taken en beschikbare taakuren wordt geredeneerd (zie bijvoorbeeld Runhaar, Gulikers, Wesselink, \& Wallenaar, 2019).

Roldifferentiatie raakt aan 'gespreid leiderschap', een concept dat veel aandacht heeft gekregen in de onderwijskundige literatuur (zie bijvoorbeeld Spillane, 2005) en waarbij leiderschap niet alleen gezien wordt als eigenschap van een individu of als een bevoegdheid gelegen in een specifieke functie, maar ook als een eigenschap van een groep (Hulsbos \& Langevelde, 2017): alle groepsleden kunnen leiderschap op zich nemen op basis van expertise en affiniteit en de verdeling van leiderschap hangt af van de behoeftes die op bepaalde momenten bestaan. Dit maakt gespreid leiderschap een dynamisch gegeven dat een informeel karakter heeft. Gespreid leiderschap binnen scholen kan echter niet los gezien worden van formeel leiderschap. Bouwmans en anderen (2017) laten in navolging van MacBeath (2005) zien hoe formele teamleiders in het mbo ruimte kunnen scheppen voor gespreid informeel leiderschap binnen onderwijsteams, waarbij teamleden elkaar leiderschap gunnen omdat men elkaars expertise en de waarde ervan over en weer erkent. Binnen de hiërarchische context van onderwijsinstellingen is ontwikkeling naar informeel gespreid leiderschap - tot op zekere hoogte - mogelijk. Bouwmans en anderen (2017) beargumenteren, in navolging van Gronn (2009) dat binnen scholen altijd sprake zal zijn van een combinatie tussen formeel en informeel leiderschap (zgn. 'hybrid leadership).

Tot slot stuitten we in de uitwerking van het geschetste onderscheid tussen taak-, functie-, en roldifferentiatie, op studies over 'job crafting'. Dit is een concept dat recent veel aandacht krijgt in onderzoek naar werkdruk en werkgeluk (zie Van Wingerden et al., 2017) en dat ook raakt aan differentiatie in onderwijsteams. Met job crafting wordt gedoeld op informele manieren waarop teamleden hun werk op zo'n manier inrichten dat dit aan hun individuele behoeften voldoet (zie Hummel et al., 2019; Leana et al., 2009). Het gaat over de variaties die leraren kunnen aanbrengen in hun werk zodat zij meer het gevoel hebben 'in control te zijn' en minder werkdruk ervaren (Van Wingerden et al., 2017). Te denken valt aan invallen voor elkaar om ruimte voor de ander te creëren; zelf samenwerkingspartners bepalen; werktijd voor een deel zelf kunnen indelen, etc. Zo wordt in het kader van de balans tussen job demands en job resources meer zwaarte aan de resource kant gecreëerd. Job crafting kan ook gericht zijn op het meer gebruik maken van de eigen sterke punten. Zo laten Van Woerkom en Meyers (2019) zien dat leraren in het primair onderwijs die kleine aanpassingen in hun taak maken zodat deze meer in lijn is met hun eigen sterke punten, meer vertrouwen krijgen in hun eigen competenties en meer acties nemen om zichzelf verder te ontwikkelen.

\section{Wat is bekend over de effecten van de inzet van verschillende vormen van differentiatie in onderwijsteams op werkdruk/verzuim, werktevredenheid en de vraag naar nieuwe leraren?}

De vraag naar effecten van taakdifferentiatie is lastig te beantwoorden vanwege het ontbreken van wetenschappelijk onderzoek. De beperkte hoeveelheid 'grijze' literatuur op dit terrein levert weliswaar inzichten op, zij het dat die zich

\footnotetext{
${ }^{5}$ Er zijn verschillende praktische voorbeelden te vinden van hoe onderwijs anders kan worden georganiseerd en wat dit betekent voor de verdeling van rollen en taken. Innovatie Impuls Onderwijs (iio) was bijvoorbeeld een project rondom vernieuwing binnen het basis- en voortgezet onderwijs, uitgevoerd het CAOP en Kennisland, in opdracht van OCW. Op iio website zijn verschillende uitwerkingen te zien van hoe onderwijs op een andere manier georganiseerd kan worden: https://www.innovatieimpulsonderwijs.nl/
} 
met name toespitsten op werkdruk. Boogaard en collega's (2004) stellen dat door taakdifferentiatie (lees: specialisatie) meer vormen van samenwerking tussen onderwijsgevenden ontstaan. Hoewel specialisatie kan leiden tot besparing van docenttijd (een specialist kan bijvoorbeeld een les één keer voorbereiden en die vervolgens aan meerdere klassen geven), kan afstemming met anderen juist weer extra tijd kosten. Anderzijds kan samenwerking weer mogelijkheden bieden tot intervisie en onderwijsvernieuwing. Of taakdifferentiatie leidt tot minder werkdruk is derhalve twijfelachtig. Taakdifferentiatie kan alleen leiden tot minder vraag naar leraren als hierbij ondersteunend personeel, zoals onderwijsassistenten of lerarenondersteuners, wordt ingezet (Boogaard et al., 2004).

In de vorige paragraaf werd duidelijk dat naast taakdifferentiatie ook andere vormen van differentiatie bestaan en dat die op verschillende manieren kan worden vormgegeven (op formele en informele manieren en op grondslag van functies of voorkeuren van medewerkers bijvoorbeeld). Samenwerken aan onderwijs, waarbij taken gedifferentieerd worden en verschillende typen professionals een rol hebben, kan zowel voor leerlingen als voor onderwijsgevenden voordelen opleveren. Hoewel er, voor zover wij weten, geen grootschalige kwantitatieve of experimentele studies gedaan zijn naar effecten van (taak)differentiatie, bieden de meer kwalitatieve studies die we hierboven aanhaalden verschillende aanknopingspunten om potentieel positieve effecten te expliciteren. Zo kan er door als team te werken meer aandacht geschonken worden aan individuele leerlingen of kleinere groepen leerlingen met specifieke behoeftes (Goetz, 2000) en kan specialisatie door onderwijsgevenden in een bepaalde inhoud of rol leiden tot kwaliteitsverhoging van het onderwijs (Van den Heuvel-Panhuizen \& De Goeij, 2005). Voor de leraren kan samenwerken aan onderwijs ook veel opleveren. Doordat men lesgebonden taken van elkaar kan overnemen, kan er tijd vrijkomen voor nietlesgebonden taken (Boogaard et al., 2004). Ook ontstaan er, zoals hierboven geschetst, meer loopbaanpaden. De mogelijkheid zich te specialiseren kan als een verrijking worden ervaren. En doordat er intensief wordt samengewerkt, ontmoet men elkaar sneller en ontstaan er automatisch meer mogelijkheden om van elkaar te leren (Meirink, Imants, Meijer, \& Verloop, 2010).

\section{Onder welke voorwaarden treden de positieve effecten op?}

De voorwaarden die eerder zijn geschetst voor een succesvolle inzet van onderwijsassistenten, lijken ook op de verschillende vormen van differentiatie van toepassing te zijn. Of het nu gaat om de inzet van onderwijsassistenten (als vorm van functiedifferentiatie) of de inzet van 'teacher leaders' (als vorm van taakdifferentiatie waarbij leraren een voortrekkersrol spelen bij onderwijsinnovaties), een duidelijke rolafbakening blijkt van cruciaal belang (Van den HeuvelPanhuizen \& De Goeij, 2005). Daarnaast wordt ook de ruimte voor professionele ontwikkeling als belangrijke factor gezien (Boogaard et al., 2004). Zo laat Vlaams onderzoek (Struyve, Meredith, \& Gielen, 2014) zien dat het voor leraren die de rol van teacher leader op zich nemen, bijvoorbeeld door expert te worden in een bepaald schoolvak en daarin binnen het team een leidende en voorschrijvende rol spelen, een verandering ervaren in de sociaal-professionele relatie met hun collega-leraren en met hun leidinggevende. Als teacher leader treden leraren toe tot de 'administratieve zone', die tot dan toe voor hen vaak onbekend terrein was, wat vervolgens tot argwaan kan leiden onder collega-leraren. Men gaat zich op een nieuwe manier tot elkaar verhouden en leren hoe dit werkt, kost van beide kanten tijd. Deze tijd moet dan ook gegeven worden (Imants, 1996). Schoolleiders dienen zich van dit proces bewust te zijn en er alles aan te doen om te laten zien dat zij de teacher leaders serieus nemen en betrekken in besluitvorming. Een duidelijke rolomschrijving en voldoende ondersteuning in tijd en ruimte voor professionele ontwikkeling en afstemming met collega's zijn dus van belang (Imants, 1996; Onderwijsraad, 2018; Van den Heuvel-Panhuizen \& De Goeij, 2005). Ook hier hieruit blijkt dat er een duidelijke visie moet zijn op ieders inzet en waarde in het onderwijsleerproces.

In lijn met de positieve psychologie benadering (Van Woerkom, 2018) kunnen we ervan uitgaan dat wanneer onderwijsprofessionals de rollen op zich nemen die passen bij hun sterke punten, zij hier mee energie van zullen krijgen en meer gemotiveerd zullen zijn dan wanneer zij taken toebedeeld krijgen op basis van, bijvoorbeeld, anciënniteit, gewoonte of beschikbare uren. Mensen verschillen van elkaar in waar zij goed in zijn. Om tot een zo optimaal teamresultaat te komen, is het daarom zinvol om na te gaan hoe ieders unieke kwaliteit zo goed mogelijk benut kan worden.

\section{Wat kunnen schoolleiders en leraren doen om verschillende vormen van differentiatie binnen onderwijsteams effectief in te zetten?}

Op basis van de vorige twee paragrafen komen we tot de volgende aanbevelingen voor schoolleiders: Maak expliciet welke rollen en taken binnen het primair proces (het geven en ontwikkelen van onderwijs) en binnen de secundaire processen (het organiseren van onderwijs) vervuld moeten worden; 
Ga na welke kwalificaties en kwaliteiten nodig zijn om de verschillende rollen en taken te vervullen;

Betrek teamleden bij het verdelen van rollen en taken;

Denk na welke rollen door externen vervuld kunnen worden, zoals ouders of actoren uit andere instellingen;

Faciliteer regelmatige gesprekken tussen teamleden over onderlinge taak- en rolafstemming;

Faciliteer de rol- en taakuitvoering in ruimte, tijd en middelen maar ook in professionaliseringsmogelijkheden;

Luister goed naar ieders loopbaanwensen en probeer de rol- en taakverdeling daar op af te stemmen.

Voor leraren en andere onderwijsgevenden komen we tot de volgende aanbeveling:

> Voer binnen het team regelmatig overleg met elkaar over de onderlinge rol-en taakverdeling en probeer tegengestelde verwachtingen te voorkomen dan wel op te lossen;

> Probeer in de rol- en taakverdeling zoveel mogelijk gebruik te maken van ieders sterke kanten en ambities.

\section{Lessons learned over differentiatie in teams}

- Differentiatie kan op verschillende manieren vormgegeven worden en meer of minder geformaliseerd worden; waar taak- en functiedifferentiatie meer formele manieren zijn om het werk te verdelen, kunnen roldifferentiatie en 'job crafting' als meer informele manieren worden beschouwd.

- Differentiatie kan enerzijds leiden tot specialisatie en daarmee tot efficiëntie en minder werkdruk; anderzijds vraagt differentiatie om samenwerking en onderlinge afstemming in, wat tijd kost.

- Randvoorwaarden voor deze positieve consequenties zijn:

Zicht op ieders kwaliteiten en interesses;

Taken verdelen op basis van ieders kwaliteiten en hierop durven vertrouwen

Duidelijkheid over afbakening van taken of rollen;

Voldoende mogelijkheden voor professionalisering

Voldoende tijd en middelen om de taken of rollen goed uit te voeren;

Een duidelijke visie op ieders inzet en waarde in het onderwijsleerproces

\subsection{Conclusie \& Discussie}

\subsubsection{Samenvatting van belangrijkste bevindingen}

Deze literatuurstudie leverde enkele specifieke onderzoeken op naar de inzet van onderwijsassistenten. Er werden weinig onderzoeken gevonden naar taakdifferentiatie in het primair onderwijs. Om deze reden is gebruik gemaakt van literatuur uit andere onderwijssectoren en is de vraagstelling rond de term taakdifferentiatie verbreed naar functie- en roldifferentiatie, job crafting en gespreid leiderschap. Op die manier hebben we de vraag 'In hoeverre, op welke manier en onder welke voorwaarden kan a) de inzet van onderwijsassistenten en b) taakdifferentiatie binnen teams bijdragen aan het terugdringen van het lerarentekort, het reduceren van werkdruk en verzuim, het verhogen van werktevredenheid en het gelijk houden of verhogen van de onderwijskwaliteit? kunnen beantwoorden.

Wat onderwijsassistenten betreft kunnen we concluderen dat zij zich het meest bezig houden met het ondersteunen en begeleiden van leerlingen, met extra begeleiding voor kinderen met een achterstand, en met surveillance- of pleinwachttaken. Studies naar effecten van de inzet van onderwijsassistenten spitsen zich voornamelijk toe op de ervaren werkdruk van leraren en niet of nauwelijks op de andere afhankelijke variabelen uit de onderzoeksvragen, namelijk verzuim, het verhogen van werktevredenheid en het gelijk houden of verhogen van de onderwijskwaliteit. De werkdrukbeleving kan naar beneden gebracht worden als aan bepaalde voorwaarden wordt voldaan, zoals rolduidelijkheid en een goede voorbereiding van onderwijsassistenten.

Omdat weinig literatuur beschikbaar was op het terrein van taakdifferentiatie zijn meerdere vormen van differentiatie bij het onderzoek betrokken. Differentiatie kan immers op verschillende manieren - meer of minder geformaliseerd en op verschillende grondslagen gebaseerd - worden vormgegeven. Waar taak- en functiedifferentiatie meer formele manieren zijn om het werk te verdelen, kunnen roldifferentiatie en 'job crafting' als meer informele manieren worden beschouwd. Ook op dit terrein werd weinig onderzoek aangetroffen over de effecten ervan en spitste het schaarse 
onderzoek dat beschikbaar was zich vooral toe op werkdruk. Ook waren onderzoeken overwegend kwalitatief van aard. Onderzoek suggereert dat differentiatie kan leiden tot specialisatie, minder werkdruk en meer werkgeluk, maar ook hier geldt dat aan bepaalde voorwaarden moet worden voldaan. Naast rolduidelijkheid betreft het hier bijvoorbeeld ook een duidelijke visie op ieders inzet en waarde in het onderwijsleerproces.

\subsubsection{Theoretische reflectie en suggesties voor vervolgstudies}

Wat in de onderzoeken naar werkdruk in het onderwijs (zie bijvoorbeeld Hummel et al., 2019) duidelijk naar voren komt, is dat een disbalans tussen taakeisen en hulpbronnen kan leiden tot stress en burn-out symptomen. Deze redenering komt duidelijk terug in de zogenoemde Job-Demands-Resources theorie die veronderstelt dat wanneer de taakeisen (zoals werkdruk) de hulpbronnen (zoals autonomie of collegiale steun) overstijgen, dit tot negatieve uitkomsten (zoals werkstress) kan leiden (Janssen in de Wal, Van den Beemt, Martens, \& Den Brok, 2018; Schaufeli \& Taris, 2013). Wanneer men het idee heeft over meer dan voldoende hulpbronnen te beschikken om de taakeisen het hoofd te bieden, dan kan dit juist tot positieve uitkomsten leiden, zoals bevlogenheid of werkgeluk. Hulpbronnen komen vaak tegemoet aan de psychologische basisbehoeften aan sociale verbondenheid, autonomie, en ervaren competentie (Jansen in de Wal et al., 2018). Het is dus de verhouding tussen negatieve en positieve werkkenmerken die bepalend is voor allerlei werkuitkomsten (Hummel, et al., 2019; Schaufeli \& Taris, 2013). In ons vervolgonderzoek nemen we de balans tussen taakeisen en werkhulpbronnen expliciet mee. Bovendien wordt steeds meer bewijs gevonden voor de positieve effecten van roldifferentiatie en job crafting (Rudolph, Katz, Lavigne, \& Zacher, 2017) dus zal in ons vervolgonderzoek, naast taak- en functiedifferentiatie ook aandacht zijn voor deze vormen van differentiatie binnen teams.

Het literatuuronderzoek bevestigt dat het vraagstuk rond 'anders organiseren', door middel van de inzet van onderwijsassistenten en differentiatie, op meerdere niveaus speelt. Differentiatie, bijvoorbeeld door de inzet van onderwijsassistenten vraagt niet alleen om aanpassingen van individuele leraren maar ook van de teams waarin zij werken. Inzet van onderwijsassistenten is bijvoorbeeld alleen effectief wanneer teamleden in overleg met elkaar inclusief onderwijsassistent - bepalen welke taken het best bij onderwijsassistenten neergelegd kunnen worden en hoe onderlinge afstemming plaatsvindt (zie bijvoorbeeld Bach et al., 2006).

Naast het individuele en het teamniveau speelt het vraagstuk rond 'anders organiseren' ook op school of bovenschool niveau. Vanuit de schoolleiding is bijvoorbeeld een duidelijke visie nodig op ieders inzet en waarde in het onderwijs waarmee het raakt het aan het schoolbrede strategisch personeelsbeleid. Met het strategisch personeelsbeleid wordt gedoeld op alle beleid en praktijken die gericht zijn op het aantrekken, behouden, ontwikkelen en belonen van leraren op zo'n manier dat het de leraar-, team- en schoolprestaties verhoogt (Runhaar, 2017). Inzet van onderwijsassistenten vraagt bijvoorbeeld om een goede werving en selectieprocedure en goede mogelijkheden voor professionele ontwikkeling en dus om een goed strategisch personeelsbeleid. Hetzelfde geldt voor differentiatie: taken en rollen verdelen binnen het team raakt aan het taakbeleid, hetgeen een wezenlijk onderdeel is van strategisch personeelsbeleid (zie ook Reezigt, Rekers-Mombarg, Bosker, \& Van der Heide, 2019). Strategisch personeelsbeleid kan worden gezien als een overkoepelende randvoorwaarde voor duurzame differentiatie in het algemeen en de inzet van onderwijsassistenten in het bijzonder. Hoewel dit in de literatuur die wij hebben bestudeerd niet expliciet zo wordt gesteld, denken wij dat 'teamgericht personeelsbeleid' (zie Bouwmans et al., 2017) een goede kapstok op operationeel niveau kan zijn voor de aanbevelingen voor schoolleiders die uit onze onderzoeken naar voren komen. In onze vervolgstudies zullen we dit, relatief nieuwe, theoretische concept dan ook verder uitwerken en in verband brengen met het vraagstuk rond anders organiseren in het primair onderwijs. In Bijlage 1 kunt $u$ een uitgebreidere uitleg van teamgericht personeelsbeleid terugvinden. 


\section{Interviewstudie met deskundigen uit de praktijk}

\subsection{Inleiding, onderzoeksvragen en doel}

Dit hoofdstuk beschrijft het tweede deelonderzoek, een interviewonderzoek onder verschillende relevante actoren uit het primair onderwijs $(\mathrm{N}=17)$. Het betreft zowel deskundigen uit het primaire en secundaire proces binnen scholen (leraren en onderwijsassistenten respectievelijk schoolleiders) als deskundigen die buiten scholen werkzaam zijn (zoals beleidsmedewerkers van de PO-Raad, Onderwijsinspectie en vervangerspoules, onderzoekers en adviseurs).

De vragen die in het interviewonderzoek centraal staan, zijn:

1. Welke oorzaken zien de (ervarings)deskundigen voor de werkdruk in het primair onderwijs?

2. Welke oplossingen voor de werkdrukproblematiek worden door de deskundigen aangedragen en in hoeverre kunnen het inzetten van onderwijsassistenten en vormen van taakdifferentiatie hier volgens hen een rol in spelen?

3. Wat zijn volgens deskundigen de randvoorwaarden voor deze interventies ter verlaging van de werkdruk?

De antwoorden op deze onderzoeksvragen geven meer inzicht in praktijken in het primair onderwijs gericht op werkdrukvermindering, het inzetten van onderwijsassistenten en het toepassen van taakdifferentiatie binnen teams. Deze inzichten zijn meegenomen in de meervoudige case studie (hoofdstuk 4) en de vragenlijststudie (hoofdstuk 5).

De inzichten uit de interviews zijn een aanvulling op de bevindingen uit het literatuuronderzoek (hoofdstuk 2), waaruit bleek dat wetenschappelijke literatuur over de inzet van onderwijsassistenten en taakdifferentiatie beperkt antwoord geeft op de centrale onderzoeksvraag van dit onderzoek. Studies naar effecten van de inzet van onderwijsassistenten spitsen zich voornamelijk toe op de ervaren werkdruk van leraren en niet of nauwelijks op de andere afhankelijke variabelen uit de onderzoeksvragen, namelijk verzuim, het verhogen van werktevredenheid en het gelijk houden of verhogen van de onderwijskwaliteit. Wel blijkt dat de werkdrukbeleving naar beneden gebracht kan worden als aan bepaalde voorwaarden wordt voldaan, zoals rolduidelijkheid en een goede voorbereiding van onderwijsassistenten. Omdat weinig literatuur beschikbaar was op het terrein van taakdifferentiatie zijn meerdere vormen van differentiatie bij het onderzoek betrokken. Onderzoek suggereert dat differentiatie kan leiden tot specialisatie, minder werkdruk en meer werkgeluk, maar ook hier geldt dat aan bepaalde voorwaarden moet worden voldaan.

Uit de grote aandacht voor de werkdrukverlagende interventies in het onderwijs in recente praktijk- en beleidsgerichte literatuur blijkt dat er behoefte is aan meer kennis over deze onderwerpen in de Nederlandse onderwijscontext.

\subsection{Gehanteerde methode}

In de periode van september tot en met november 2019 zijn door de onderzoekers interviews afgenomen onder representanten van alle voor ons onderzoek relevante actoren. Voor een zo compleet mogelijk beeld hebben we voor respondenten gekozen met kennis, ervaring en expertise vanuit de volgende vier perspectieven: 1) het primaire proces-perspectief, door respondenten met onderwijsgevende functies, 2) het organisatieperspectief, door respondenten met ervaring op het gebied van scholen(gemeenschappen), teams of organisatiekennis en -kunde, 3) het opleidingsperspectief, door respondenten die werkzaam zijn binnen de beroepsopleidingen tot onderwijsgevenden, en 4 ) het sectorperspectief, door respondenten met functies op sectoraal en nationaal niveau. In vier gevallen spreken de respondenten vanuit twee verschillende perspectieven. Tabel 3.1 laat zien hoeveel interviews er met welke categorie actoren zijn afgenomen, en vanuit welk perspectief de geïnterviewden spraken. 
Tabel 3.1 Rollen van geïnterviewden, en het perspectief van waaruit zij spreken, $\mathbf{N}=17$.

\begin{tabular}{|c|c|c|c|c|c|}
\hline \multirow[t]{2}{*}{ Respondent type } & \multicolumn{4}{|c|}{ Perspectieven } & \multirow[t]{2}{*}{ Totaal } \\
\hline & Sector & Organisatie & Primaire proces & Opleiding & \\
\hline Schoolleider & & $3^{6}$ & & & 3 \\
\hline Leraar & & & $2^{7}$ & & 2 \\
\hline Onderwijsassistent & & & 2 & & 2 \\
\hline Beleidsmedewerker sectoraal & 1 & & & & 1 \\
\hline Onderzoeker & 1 & 2 & & $1^{8}$ & 4 \\
\hline $\begin{array}{l}\text { Beleidsmedewerker flexibele schil/ } \\
\text { vervangerspoule }\end{array}$ & 3 & & & & 3 \\
\hline HR-adviseur onderwijs & & 1 & & & 1 \\
\hline $\begin{array}{l}\text { Coördinator opleiding } \\
\text { lerarenondersteuner }\end{array}$ & & & & 2 & 2 \\
\hline $\begin{array}{l}\text { Coördinator opleiding academische } \\
\text { pabo }\end{array}$ & & & & 1 & 1 \\
\hline $\begin{array}{l}\text { Student Associate Degree } \\
\text { onderwijsopleiding }\end{array}$ & & & $1^{9}$ & & 1 \\
\hline $\begin{array}{l}\text { Inspecteur en onderzoeker } \\
\text { Onderwijsinspectie }\end{array}$ & 1 & & & & 1 \\
\hline
\end{tabular}

De respondenten zijn allen benaderd op basis van het netwerk van (medewerkers van) OCW, WUR en UvT. Dit leidde in sommige gevallen tot een sneeuwbaleffect: door in gesprek te raken met actoren, zijn nieuwe contactgegevens voor andere respondenten vergaard. De potentiele respondenten zijn allen gemaild of gebeld met een uitleg over het onderzoek en de vraag naar een afspraak. Deze vonden voor een deel telefonisch plaats en duurden 30 tot 45 minuten. Een deel van de interviews vond face-to-face plaats. Deze interviews duurden 45 tot 60 minuten.

De gehanteerde topiclijst van de afgenomen interviews die zich richt op de concepten uit de onderzoeksvragen en doelen is bijgevoegd in bijlage 2. Deze werd in de meeste gevallen van te voren aan de respondenten verzonden en diende als richtlijn tijdens de interviews. Na het afnemen van de interviews is een verslag geschreven en voorgelegd aan de respondenten. Op basis van deze interviewverslagen werd een datamatrix geconstrueerd die de antwoorden per topic (zie topiclijst) weergeeft opdat patronen konden worden geëxpliciteerd.

De resultaten zijn in dit verslag gestructureerd aan de hand van de drie onderzoeksvragen.

\subsection{Bevindingen}

Hieronder worden de bevindingen met betrekking tot bovengenoemde onderzoeksvragen beschreven. Bij het beschrijven van de resultaten hieronder zijn we in de formuleringen dicht bij die van de respondenten gebleven.

\subsubsection{Oorzaken van de werkdruk in het onderwijs}

In deze paragraaf wordt antwoord gegeven op de onderzoeksvraag: welke oorzaken zien de (ervarings)deskundigen voor de werkdruk in het primair onderwijs? De paragraaf is gestructureerd aan de hand van de bevindingen per perspectiefgroep, waarbij de sectorale en organisatiedeskundigen zijn samengevoegd.

\footnotetext{
${ }^{6} 2$ van de 4 schoolleiders hebben samen deelgenomen aan 1 interview.

71 leraar is ook onderwijsassistent

81 onderzoeker is ook coördinator opleiding academische pabo

91 werkzaam als onderwijsassistent, is ook student Associate Degree opleiding Pedagogisch Educatief Professional
} 
De respondenten bemerken een toename van de werkdruk in het Nederlandse primair onderwijs die veelal parallel loopt aan de toenemende lerarentekorten. Ze hebben verschillende ervaringen met de oorzaken van de werkdruk, die hieronder worden toegelicht.

\section{Leraren en onderwijsassistenten}

De (ex-)leraren, onderwijsassistenten en lerarenondersteuners die wij tijdens de interviews spreken, voorheen of momenteel betrokken bij het primaire proces, geven verschillende werkdrukoorzaken aan. Zo wordt door hen meermaals genoemd dat het onderwijsgevende personeel de toenemende vervangingsbehoefte niet kan opvangen. Dit wil zeggen dat bij ziekte of andere uitval (zwangerschapsverlof, pensioen) het overige personeel de gaten niet kan vullen. Hiervoor worden vaak en op incidentele wijze de onderwijsassistenten uit het personeelsbestand ingezet. Als de onderwijsassistent volwaardige lessen moet overnemen en als leraren van de parallelklassen verantwoordelijkheid voelen voor het zelfstandig werken van de onderwijsassistent, leidt dit op meerdere plekken tot een verhoging van de ervaren werkdruk.

Naast bovengenoemde oorzaak van werkdruk noemen meerdere leraren en onderwijsassistenten ook een verschil in ervaren werkdruk als de workload in principe hetzelfde is. Zij nemen waar dat werkdrukbeleving daarmee subjectief is, en dat kenmerken van de individuele leraren van invloed zijn op de mate waarin de werkdruk wordt beleefd. Voorbeelden die genoemd worden zijn: een groot verantwoordelijkheidsgevoel hebben, moeite hebben met omgaan met mondigheid van ouders, en veel taken uitvoeren die niet bijdragen aan de eigen professionele doelen.

\section{Schoolleiders}

Alle drie de geïnterviewde schoolleiders geven, net als de respondenten uit het primaire proces, aan dat vanwege het lerarentekort de 'rek' binnen onderwijsteams in Nederlandse scholen er vaak uit is en de vervangingsbehoefte dus groter is dan het lerarenaanbod.

Een andere door schoolleiders genoemde oorzaak van werkdrukgevoelens betreft kenmerken van de taak: de administratieve last is hoog, duobanen vragen veel overleg en er is een grote hoeveelheid aan randactiviteiten naast de lesgevende taken. Er valt tevens winst te behalen in de werkdrukbeleving van leraren door onderwijsconcepten waarmee gewerkt wordt simpeler en overzichtelijker te maken. Er is een complex geheel aan (verplichte) procedures en manieren van werken, leermethodes, werkvormen - die ook allemaal administratief geregistreerd moeten worden. Dit geeft veel druk. De hoeveelheid aan secundaire taken die een leraar moet doen ten opzichte van de primaire taken is daarmee niet in balans. Daarnaast kan volgens schoolleiders de disbalans tussen werk en privé (zoals gezinnen en hobby's) die door bovenstaande aspecten in de hand wordt gewerkt, voor meer ervaren werkdruk zorgen.

Door bovenstaande redenen raakt het voor de klas staan en contact hebben met de kinderen volgens een schoolleider vaak ondergesneeuwd, terwijl dit contact juist vaak energie oplevert. Schoolleiders benoemen tevens dat binnen scholen voor primair onderwijs niet altijd sprake is van een professionele cultuur met een open communicatie en het geven van feedback. Ook dit kan in hun ogen bijdragen aan de ervaren werkdruk.

\section{Bovenschoolse en sectorale medewerkers}

De respondenten die bovenschools en sectoraal werken als beleidsmedewerker of onderzoeker (zie tabel 3.1) bemerken evenzeer een grote vervangingsbehoefte in het po, die in eerste plaats ziekte van werknemers, maar ook zwangerschaps- en ouderschapsverloven betreft. Voor een kleiner deel betreft de vervanging het opvullen van uren die vrijkomen door oudere werknemers die minder gaan werken als zij tegen hun pensioen aanlopen.

Het is ook volgens de respondent die werkzaam is bij een academische pabo duidelijk zichtbaar dat (academische) pabo's de vervangingsvraag die optreedt door het toenemende lerarentekort niet kunnen beantwoorden. De medewerkers en studenten van verschillende opleidingen die we spreken, geven ook aan dat de vraag naar onderwijsassistenten en leraren(ondersteuners) momenteel heel groot is.

Tot slot merken verschillende geïnterviewde sectorale beleidsmedewerkers en HR-deskundigen nog een andere oorzaak van werkdruk op, namelijk het gebrek aan strategisch personeelsbeleid en aan een lange termijn onderwijsvisie in scholen. Volgens hen richten veel scholen hun beleid in op basis van een korte termijnvisie. Zo kunnen problemen, zoals het lerarentekort, niet preventief aangepakt worden. Een beleidsmedewerker van een vervangerspoule geeft 
bijvoorbeeld aan dat de inzet van vervangers via externe poules nu vaak ad hoc vormgegeven wordt op het moment dat een knelpunt zich voordoet. Een schoolleider geeft daarnaast aan dat hij ziet dat scholen in zijn netwerk niet voorbij het huidige schooljaar kijken als het over de verhouding leraren/leerlingen gaat. Een andere respondent, die als leraar uit het po is gestapt omdat hij ervaarde zijn expertise niet kwijt te kunnen in zijn functie als leraar, begeleidt om die reden scholen bij de vormgeving van hun strategisch personeelsbeleid.

\subsubsection{Mogelijke oplossingen voor de werkdrukproblematiek}

In deze paragraaf wordt antwoord gegeven op de onderzoeksvraag: welke oplossingen voor de werkdrukproblematiek worden door de deskundigen aangedragen en in hoeverre kunnen het inzetten van onderwijsassistenten en vormen van taakdifferentiatie hier volgens hen een rol in spelen? De paragraaf is gestructureerd aan de hand van de twee categorieën oplossingen waaronder de bevindingen vanuit de verschillende perspectieven vallen, namelijk diversiteit aan expertises in onderwijsteams en verdeling van rollen en taken.

\section{Diversiteit aan expertises in onderwijsteams}

Een voormalig leraar en inmiddels personeelsadviseur in het onderwijs pleit voor veel meer verschillende expertises in onderwijsteams door niet alleen pabo-geschoolde leraren in te zetten, maar ook teamleden met andere achtergronden te integreren. Hij noemt bijvoorbeeld academische leraren, lerarenondersteuners, onderwijsassistenten, zij-instromers met ervaringen buiten het onderwijs, en pedagogen. Ook de andere respondenten zoeken veelal de oplossing voor de werkdrukproblematiek in uitbreiding van de onderwijsteams voorbij de kaders van de traditioneel opgeleide leraar.

Wat onderwijsassistenten betreft was hier tot een aantal jaren geleden volgens de respondenten uit het opleidingsveld weinig tot geen behoefte aan in het po. Deze behoefte is de afgelopen jaren echter flink toegenomen. Volgens de respondenten uit de opleidingen is er te weinig geanticipeerd op de krapte op de arbeidsmarkt en heeft het gebrek aan lange termijn vooruitdenken door scholen ertoe geleid dat de vraag naar onderwijsassistenten en leraren(ondersteuners) nu heel groot is. Vanuit de wens van scholen om meer onderwijsassistenten in te zetten, is ook de noodzaak om mensen hiervoor op te leiden de laatste jaren erg gegroeid. Helpen aan deze wens te voldoen is zodoende een belangrijk doel van de verschillende opleidingen. Maar opleidingen benoemen daarnaast andere aspecten van deze hulpvraag, namelijk (a) het belang van het beter positioneren van de onderwijsassistent op de arbeidsmarkt, (b) het verbeteren van de doorstroom van onderwijsassistenten naar het hbo (specifiek pabo) en (c) het belang van het binnenhalen van experts in onderwijsteams op het gebied van individuele begeleiding van leerlingen.

De vervangingsbehoefte in po, die wordt veroorzaakt door het toenemende lerarentekort, wordt door alle respondentengroepen opgemerkt. Om aan deze behoefte te voldoen zijn meerdere van de respondenten betrokken bij vervangerspoules, waarbij er bemiddeld wordt tussen scholen en flexibele krachten die begeleiding en bijscholing ontvangen om de taken waar zij voor worden ingehuurd goed in te kunnen vullen. Het beschikbare aanbod binnen de vervangerspoules begint echter langzamerhand krap te worden in verhouding tot de vraag. De drie respondenten die werkzaam zijn op het gebied van vervangerspoules geven aan dat deze nog vooral gericht zijn op de vervangende inzet van leraren. Men bemerkt nog niet veel vraag naar onderwijsassistenten (een respondent noemt: $14 \%$ van de aanvragen) en slechts zeer sporadisch naar lerarenondersteuners. Als er onderwijsassistenten gevraagd worden dan is dit vooral vanwege concrete klussen in het speciaal onderwijs, zoals begeleiding van leerlingen die extra hulp en aandacht nodig hebben. De respondenten erkennen dat vervangende inzet van onderwijsassistenten voordelen kan hebben: het zou de werkdruk van leraren omlaag kunnen brengen als er meer handen in de klas aanwezig zijn.

Naast vervangerspoules vertellen twee van onze respondenten werkzaam in de branche van flexibele medewerkers ook over initiatieven waar schooloverstijgende vakspecialisten in worden gezet op scholen. Dit gebeurt dan bijvoorbeeld in de vorm van themadagen of -dagdelen waarin op een speelse manier aandacht wordt besteed aan bijvoorbeeld motorische ontwikkeling of de anatomie van het lichaam. Deze themadagen, zo vertelt een respondent die werkzaam is bij een vakspecialisteninitiatief, werden voorheen vaak ingezet op het moment dat er uitval was op een school dat niet opgevuld kon worden door het eigen personeel. Inmiddels maakt men ook op meer structurele basis gebruik van de schooloverstijgende vakspecialisten. De respondent geeft aan dat de reacties van scholen namelijk zeer positief zijn en dat ook de aanbieders enthousiast zijn. Dit zijn vaak (ex)leraren die zich op deze manier kunnen richten op de stof en taken die ze echt interessant vinden. 
Een van de respondenten is daarnaast betrokken bij het werven en opleiden van zij-instromers, in samenwerking met een regionale pabo. Het doel van deze samenwerking is de kwantiteit van onderwijsprofessionals te vergroten, maar ook om de kwaliteit van deze toekomstige leraren te waarborgen.

Een respondent werkzaam bij een academische pabo vertelt dat academische leraren een aanvullende rol binnen het onderwijsteam kunnen spelen op basis van hun opleidingsachtergrond. Vaak worden zij als aparte categorie gezien, in scholen, onderzoek en beleid. Volgens haar is dit enerzijds terecht: academische leraren hebben aanvullende kennis en vaardigheden die een team kunnen versterken en zijn ook op zoek naar andere uitdagingen. Anderzijds is het onterecht: zij hebben dezelfde taken als elke andere leraar. Hieruit blijkt nog een gebrek aan duidelijkheid over het taakbeleid van deze groep leraren en de rol die zij in het onderwijsteam (kunnen) vervullen.

\section{Verdeling van rollen en taken}

Twee schoolleiders vertellen dat een aantal rollen binnen hun school anders is verdeeld dan voorheen, namelijk op basis van kwaliteiten en interesses. Door bepaalde taken bij één collega te plaatsen, worden de andere teamleden ontlast. Door beschikbare uren voor een taak op deze manier te concentreren bij een persoon kan het bijdragen aan de kwaliteit van het onderwijs; iemand heeft bijvoorbeeld ruimte in zijn jaartaak om zich te verdiepen in coöperatief leren of bewegingsonderwijs.

Ook de eerdergenoemde schooloverstijgende vakspecialisten kunnen een specialistisch takenpakket bekleden binnen het team. Door taken te verdelen op basis van kwaliteiten en interesses kunnen de persoonlijke voorkeuren van leraren worden omgezet in formele taken. Voorheen werden interesses 'erbij' gedaan en werden bijvoorbeeld ICT-taken in de avonduren uitgevoerd. Nu is hier een formele taakomschrijving aan gekoppeld. Hierdoor wordt tegemoet gekomen aan de interesses en talenten van de leraren en wordt voorkomen dat leraren vertrekken omdat zij niet tot hun recht komen in hun werk. Volgens de geïnterviewde schoolleiders en een aantal andere organisatie-experts vergroot een erkenning als specialist zodoende de motivatie van een leraar voor het verzorgen van kwalitatief hoogstaand onderwijs. Teamleden gaan dan tevens bij elkaar te rade en dat vergroot de professionele leercultuur, omdat duidelijk is bij wie men voor een bepaalde expertise terecht kan.

De respondent werkzaam bij een academische pabo geeft aan dat academische leraren een eigen specialistisch takenpakket zouden kunnen bekleden. Naast lesgeven hebben zij andere kennis en vaardigheden in huis, zoals expertise rondom onderwijsontwikkeling. Hiervan kan meer gebruik worden gemaakt, wat zowel de onderwijskwaliteit als de motivatie van de leraren ten goede komt. Een heldere taakomschrijving voor academische leraren binnen het onderwijsteam zou voor alle teamleden de balans tussen werkdruk en werkgeluk ten goede kunnen komen.

\subsubsection{Belangrijke randvoorwaarden}

In deze paragraaf wordt antwoord gegeven op de onderzoeksvraag: wat zijn volgens deskundigen de randvoorwaarden waaronder bovengenoemde interventies leiden tot een verlaging van de werkdruk en verhoging van het werkgeluk? De paragraaf is gestructureerd aan de hand van de twee categorieën randvoorwaarden waaronder de bevindingen vanuit de verschillende perspectieven vallen, namelijk strategisch personeelsbeleid en context- en teamgericht personeelsbeleid.

\section{Strategisch personeelsbeleid}

De respondenten bemerken een afwachtende houding bij schoolbesturen ten opzichte van personeelsbeleid. De inzet van vervanging en onderwijsassistenten gebeurt nu namelijk nog vaak ad hoc en overal op een andere manier. Uit bovenstaande bevindingen blijkt dat er behoefte is aan de formulering van lange termijnbeleid over vervanging en de inzet van onderwijsassistenten wat een structurele oplossing kan bieden voor de hoge werkdruk.

Meerdere respondenten uit het primaire proces benoemen dat onderwijsassistenten een structurele oplossing voor de werkdruk kunnen bieden, mits de taakverdeling helder is. In een van de besproken schoolsituaties waar de onderwijsassistenten en leraren nauw samenwerken, levert deze samenwerking de beide groepen veel minder werkdruk op, volgens een geïnterviewde onderwijsassistent. Aanvankelijk was de rol van onderwijsassistent vooral gericht op fysieke ondersteuning, zoals tafels schoonmaken en instructies uitdelen, maar gaandeweg is de rol verrijkt naar begeleiding van (groepjes) leerlingen. Onderwijsassistenten helpen nu bijvoorbeeld in kleuterklassen bij taken zoals kleuren sorteren en tellen, en halen meer plezier uit hun werk doordat ze meer contact hebben met de leerlingen 
en hen kunnen zien groeien. Volgens deze respondent is het vaak zo dat de leraar aangeeft wat er moet gebeuren, maar steeds vaker staan leraren er ook voor open dat een onderwijsassistent zelf met ideeën komt. Dit is voor de assistenten erg motiverend: zij kennen de doelgroep immers en weten wat ze aankunnen. Inmiddels werken op deze school de leraar en onderwijsassistent door heldere afstemming van taken en verantwoordelijkheden goed samen in een groep, waar beiden zich verantwoordelijk voelen en elkaar aanvullen. Een andere onderwijsassistent vertelt ons daarnaast dat, nu bij haar op school de samenwerking met de leraren heel nauw is, er sprake is van beduidend minder werkdruk. Ook hier is men gebaat bij een heldere taakverdeling, en wordt initiatief vanuit de onderwijsassistent gewaardeerd en serieus genomen.

Verschillende respondenten beschrijven de voordelen van een verdeling van specialismen op basis van kwaliteiten en interesses. Belangrijk is volgens de geïnterviewde schoolleiders dat deze differentiatie formeel is vormgegeven door er een taakomschrijving aan te koppelen. Hierdoor is voor iedereen duidelijk wat het specialisme inhoudt en ook hoeveel uren dit vraagt. Hier profiteert volgens hen het hele team van.

De lerarenondersteuner die wij interviewen vertelt hierover dat er geen formele functie voor lerarenondersteuner bestaat, met als gevolg dat er geen salarisindicatie bestaat in termen van schalen. Dit heeft tot gevolg dat men financieel gezien niet kan doorgroeien binnen de school. Hiervoor zal men zich moeten wenden tot het vso of doorgroeien in het regulier basisonderwijs. We horen in de interviews met respondenten uit de opleidingen geluiden van dezelfde strekking. De opleiding tot Lerarenondersteuner staat in feite nog in de kinderschoenen. Het is nu immers nog een specialisatie van een pedagogische opleiding, terwijl onderwijsassistentie voor het vo en mbo al meer is uitgekristalliseerd. Er liggen nog kansen om deze functie in te passen in het functiebouwwerk om zo de doorlopende ontwikkeling van onderwijsprofessionals mogelijk te maken.

Een aantal van de respondenten die we speken vanuit het sectorperspectief is betrokken bij vervangerspoules, waarbij er bemiddeld wordt tussen scholen en flexibele krachten. De respondenten vertellen dat de inzet van onderwijsassistenten en leraren als invalkracht uit de flexibele schil kan dienen als tijdelijk puzzelstukje van een probleem. Maar de vraag is heel groot en vervangerspoules zijn dus geen structurele oplossing. De inzet van vervangers uit vervangerspoules wordt nu vaak ad hoc vormgegeven, net als de inzet van onderwijsassistenten en specialisten. Het doel zou echter moeten zijn toe te werken naar goed werkgeverschap waar uiteindelijk minder vervanging nodig is. Daarvoor is het raadzaam om krachten te bundelen tussen scholen en vervangerspoules en personeelsbeleid te verbeteren met een flexibele schil, in plaats van noodgedwongen veel geld uit te geven aan vervangers.

\section{Context- en teamgericht personeelsbeleid}

Het strategisch personeelsbeleid met duidelijke taakverdelingen en wederzijdse verantwoordelijkheid van onderwijsassistenten en leraren vergt voor een groot deel maatwerk: personeelsbeleid waarbij specialismen zijn vormgegeven is contextafhankelijk en de constructie hiervan vergt aandacht. Een voorbeeld van contextgericht inzetten van onderwijsassistenten wordt gegeven door een schoolleider. Mede dankzij de werkdrukmiddelen zijn twee onderwijsassistenten aangesteld op zijn school, die op basis van hun expertise worden ingezet in het onderwijs. $\mathrm{Zij}$ worden begeleid door de intern begeleiders en spreken samen met hen en met de leraren van de groep waarin zij ondersteunen af wat de taken zijn die ze vervullen. De onderwijsassistenten worden dus ingezet in het onderwijs, in verschillende groepen. De meerwaarde is volgens deze schoolleider vooral dat zij structureel ingezet kunnen worden, in plaats van als een puzzelstukje voor een incidenteel probleem.

De geïnterviewde personeelsadviseur benadrukt het belang van autonomie voor teams door hen het HRM-beleid mede vorm te laten geven. Om context gebonden beleid te realiseren is het essentieel dat ze zelf onderling afspraken maken en vastleggen en waar ze eigenaarschap over voelen.

Helaas bemerkt men wel dat lerarenteams vaak 'verandermoe' zijn en het ontwikkelen van een HRM-beleid zien als een rigoureuze en veelomvattende verandering. Het aangaan van de uitdaging om meer vanuit taakdifferentiatie te denken, is daar onderdeel van. Het is daarom van belang om, naast een lange termijnvisie op deze verandering, ook quick wins na te streven. Uitgaan van kleine stappen maakt de drempel tot veranderen ook kleiner, zoals het onderling benoemen en erkennen van kwaliteiten binnen teams. Bovendien kan in een aantal situaties een kleine stap al grote positieve 
veranderingen te weeg brengen, zo stelt de respondent die scholen begeleidt bij de vormgeving van hun strategisch personeelsbeleid.

De respondenten uit de opleidingen benoemen dat leraren behoefte hebben aan (rooster)vrije uren, dagdelen en zelfs dagen om ruimte te hebben om na te denken. Deze ruimte scheppen zou de ervaren werkdruk aanzienlijk kunnen verlichten. Op de school van een van de geïnterviewde schoolleiders werken nu in dat kader twee boventallige medewerkers: een leraar en een onderwijsassistent, die geregeld klassen overnemen zodat het andere onderwijspersoneel zich bezig kan houden met de taken buiten de klas (bijvoorbeeld administratie taken). Door de tijd die vrijkomt voor de secundaire taken ervaren de leraren veel verlichting in de werkdruk.

\subsection{Conclusie}

\subsubsection{Puntsgewijze samenvatting van de belangrijkste bevindingen}

Hieronder is puntsgewijs aangegeven wat de belangrijkste bevindingen zijn die uit deze deelstudie naar voren kwamen.

Welke oorzaken zien de (ervarings)deskundigen voor de werkdruk in het primair onderwijs? De top drie van belangrijkste oorzaken zijn volgens de respondenten:

> Het landelijk lerarentekort, merkbaar in de school, vooral gezien de grote vervangingsbehoefte;

$>$ Weinig ruimte binnen de werkdag van leraren voor het primaire proces, door de kenmerken van de toegenomen (secundaire) taken die zij uitvoeren;

> Gebrek aan strategisch personeelsbeleid: incidentele oplossingen in plaats van structurele oplossingen.

Welke oplossingen voor de werkdrukproblematiek worden door de deskundigen aangedragen en in hoeverre kunnen het inzetten van onderwijsassistenten en vormen van taakdifferentiatie hier volgens hen een rol in spelen? Volgens de respondenten spitsen de oplossingen zich enerzijds toe op het benutten van diversiteit aan expertise, anderzijds op het verdelen van rollen en taken.

Diversiteit aan expertises in onderwijsteams:

> Inzet van onderwijsassistenten verlicht de werkdruk als er sprake is van goede afspraken tussen leraren, andere teamleden en onderwijsassistenten, en voldoende autonomie;

> Flexibele krachten uit vervangerspoules en bovenschoolse vakspecialisten kunnen, indien structureel ingezet, bijdragen aan oplossen van grote vervangingsbehoefte;

> Zij-instromers en academische leraren dragen bij aan verhogen van de kwantiteit en kwaliteit van onderwijsteams.

Verdeling van rollen en taken:

Taakverdeling op basis van kwaliteiten en interesses, en specialistische takenpakketten op basis van diverse achtergronden en expertises kunnen

> Het werkgeluk verhogen en de werkdruk verlichten;

> Teamwerk faciliteren;

$>$ De professionele leercultuur verhogen.

Wat zijn volgens deskundigen de randvoorwaarden voor deze interventies ter verlaging van de werkdruk? Deze randvoorwaarden zijn enerzijds te koppelen aan strategisch personeelsbeleid, anderzijds aan meer context- en teamgericht personeelsbeleid.

Strategisch personeelsbeleid:

Lange termijn visie en beleid;

Heldere en formele afstemming van taken en verantwoordelijkheden;

Integratie van onderwijsassistenten en lerarenondersteuners in het functiebouwwerk;

Personeelsbeleid verstevigen met structurele samenwerking vervangerspoules en vakspecialisten. 
Context- en teamgericht personeelsbeleid:

> Teams zelf de regie over het teambeleid;

>ok quick wins en kleine stappen zijn nastrevenswaardig;

> Ruimtecreatie, bijvoorbeeld door boventallige medewerkers.

\subsubsection{Suggesties voor het vervolgonderzoek (hoofdstukken 4 en 5)}

In deze afsluitende paragraaf wordt beschreven welke adviezen op het gebied van de andere deelonderzoeken, namelijk het meervoudige casusonderzoek en het vragenlijstonderzoek, de geïnterviewden ons meegeven om een representatief en relevant antwoord te geven op de onderzoeksvraag.

\section{De vragenlijst}

Veel van de respondenten drukken ons op het hart naar de behoefte van scholen zelf te vragen, om te voorkomen dat we iets ontwikkelen wat niet gebruikt en gelezen wordt of niet praktisch toepasbaar blijkt. Een expertpanel van leraren, onderwijsassistenten en schoolleiders, waaraan we onze resultaten en ideeën voor aanbevelingen en verspreiding kunnen toetsen, zou hiervoor een zinvolle methode kunnen zijn. Ten slotte noemt men dat er inmiddels vele routes naar het leraarschap zijn. De vraag die daarbij gesteld wordt, is: krijg je daar ook instroom van leraren met verschillende specialismen van, bijvoorbeeld voor zij-instromers en academische leraren?

\section{De casusonderzoeken}

Respondenten geven aan dat via LinkedIn een oproep plaatsen en mensen zich zelf aan te laten melden voor deelname aan het onderzoek heel zinvol is. Zo verloopt het leggen van contact met (trotse) scholen op initiatief van henzelf en zullen mensen graag met ons in gesprek gaan. Daarbij dienen we niet te vergeten om besturen uit krimp- en groeiregio's mee te nemen. In krimpregio's zag een onderzoeker met organisatie-expertise dat er veel meer werd samengewerkt binnen en tussen scholen. Ook het verzamelen van casussen in zowel stad als platteland is zinvol. Schoolleiders geven bijvoorbeeld aan meer moeite te hebben met het 'lokken' van jonge werknemers naar kleine plattelandsscholen dan naar scholen in de stad. De verschillen tussen de regio's zouden dus interessante informatie kunnen opleveren.

Meerdere respondenten lijkt het zinvol om uit te zoeken wie het strategisch personeelsbeleid vormgeeft en realiseert in basisscholen, als het al een plek heeft. Daarnaast is het volgens een schoolleider interessant om op zoek te gaan naar de motieven voor het werken in het onderwijs. Deze kunnen ook van invloed zijn op de werkbeleving. 


\section{Meervoudige casestudie}

\subsection{Inleiding}

Het voorliggende hoofdstuk beschrijft de bevinden van een meervoudige casestudie, waarin wordt voortgeborduurd op inzichten die de eerdere deelstudies hebben opgeleverd. Voordat we reflecteren op de belangrijkste inzichten, en we het conceptuele raamwerk en de opzet presenteren van de voorliggende studie, blikken we eerst terug op die eerdere deelstudies.

Het literatuuronderzoek en de interviewstudie bevestigden dat het oplopende lerarentekort een belangrijke bron is voor de toename van werkdruk in het onderwijs. Leraren ervaren steeds vaker een disbalans tussen taakeisen en hulpbronnen: terwijl de hoeveelheid en complexiteit van het werk is toegenomen (denk aan grotere klassen, meer administratieve taken, meer diverse leerling populatie) is de regelruimte (in termen van autonomie, inspraak en steun vanuit collega's of leidinggevenden) vaak afgenomen. Deze disbalans kan leiden tot stress en burn-out symptomen.

De inzet van onderwijsassistenten kan deze disbalans verminderen, mits aan een aantal voorwaarden voldaan wordt, zoals een duidelijke (onderwijskundige) visie op hun inzet, goede afstemming met de taken van leraren en voldoende professionaliseringsmogelijkheden. Hetzelfde geldt voor andere vormen van taakdifferentiatie, zoals de inzet van lerarenondersteuners of groepsoverstijgende inzet van gespecialiseerde leraren of andere onderwijsprofessionals. Taakverdeling op basis van kwaliteiten en interesses kan het werkgeluk verhogen en de werkdruk verlichten, als hier een duidelijke onderwijskundige visie aan ten grondslag ligt en wanneer het is ingebed in het schoolbrede personeelsbeleid.

\subsection{Teamgericht HRM als conceptueel kader}

De focus en opzet van deze meervoudige casestudie zijn geïnspireerd op de bevindingen uit de eerdere deelstudies en op de principes van teamgericht HRM. Met teamgericht HRM wordt gedoeld op HRM praktijken die gericht zijn op het bevorderen van het functioneren van teams middels het vergroten van de capaciteiten, motivatie en mogelijkheden van teamleden om samen te kunnen werken aan de ontwikkeling en uitvoering van onderwijs (zie, bijvoorbeeld, Bouwmans, Runhaar, Wesselink, \& Mulder, 2017). De basis voor deze benadering wordt gevormd door de 'AMO theory of Perfomance' (Appelbaum, Bailey, Berg, Kalleberg, \& Bailey, 2000) - die stelt dat het functioneren van medewerkers een functie is van hun capaciteiten (Ability) en motivatie (Motivation) enerzijds en de mogelijkheden (Opportunity) die hen geboden worden om optimaal te functioneren anderzijds. Deze theorie staat aan de basis van het gedachtegoed rond Strategisch HRM zoals dit recent in de po sector is geïntroduceerd ${ }^{10}$, maar heeft ook in de vo sector ${ }^{11}$ en de mbo sector $^{12}$ als inspiratie gediend voor het denken over HRM.

Door Bouwmans en collega's (2017) en Runhaar en collega's (2018) is de AMO-theorie gelinkt aan teamwerk en is beschreven waar het in teamgericht personeelsbeleid om draait, namelijk:

$>$ dat er in de samenstelling van teams gekeken wordt naar hoe teamleden elkaar aanvullen qua capaciteiten en dat het professionaliseringsaanbod gericht is op wat teams nodig hebben om beter samen te kunnen werken en om goede team resultaten te behalen (Ability);

$>\quad$ dat teams gewaardeerd worden voor het behaalde teamresultaat en dat medewerkers gewaardeerd worden voor hun individuele bijdrage aan het teamresultaat (Motivation);

$>\quad$ dat er mogelijkheden zijn voor teams om samen te werken en te werken aan verbeterambities (Opportunity).

Teamgericht HRM raakt aan alle aanbevelingen die uit de eerdere deelstudies zijn voortgekomen. Denk bijvoorbeeld aan 'teamgerichte' werving en selectie van onderwijsassistenten: omdat teamleden weten voor welke taken assistentie gewenst is en welke kwaliteiten daarvoor nodig zijn, is het logisch hen bij de werving en selectie te betrekken.

\footnotetext{
10 https://www.samenslimmerpo.nl/document/onderzoek-strategisch-personeelsbeleid-het-primair-onderwijs-gion

${ }^{11}$ https://www.vo-raad.nl/themas/organisatie-ontwikkeling/onderwerpen/strategisch-hrm

12 https://www.nro.nl/sites/nro/files/migrate/teamleiders-aan-het-roer-van-teamontwikkeling.pdf
} 


\subsection{Onderzoeksvragen binnen de meervoudige casestudie}

De volgende deelvragen stonden in deze meervoudige casestudies centraal:

1. Hoe worden de rol- en taakverdeling binnen de (sub)teams vorm gegeven?

2. Wat is de rol van de onderwijsassistenten binnen de (sub)teams?

3. Op welke manier vinden de processen van werving en selectie voor de (sub)teams plaats?

4. Welke ontwikkelmogelijkheden hebben de leden van de (sub)teams?

5. Hoe worden individuele bijdragen aan het teamresultaat en behaalde teamresultaten geëvalueerd en gewaardeerd?

6. Welke mogelijkheden worden gecreëerd voor teams om samen te werken en te werken aan verbeterambities?

7. In welke mate draagt de manier van teamwerken bij aan: omgaan met het lerarentekort, het reduceren van werkdruk en verzuim, het verhogen van werkgeluk en het gelijk houden of verhogen van de onderwijskwaliteit?

In de loop van 2020 is daar - vanwege de plotseling optredende COVID-19 pandemie - nog de volgende vraag aan toegevoegd:

8. Op welke manier hebben de maatregelen rondom de COVID-19 pandemie effect gehad op de manier waarop er wordt samengewerkt binnen het team?

\subsection{Gehanteerde methode}

\subsubsection{Participerende Primair Onderwijsteams}

Vijf scholen hebben deelgenomen aan deze deelstudie. Het contact met deze vijf scholen is tot stand gekomen na eigen aanmelding bij het onderzoeksproject naar aanleiding van een oproep op LinkedIn ${ }^{13}$ (Berichtgeving 5), via Didactief ${ }^{14}$ en op een netwerkbijeenkomst van de PO-Raad in oktober 2020. Hierin werd aangegeven dat wij op zoek waren naar good practices. Wij vermeldden dat wij in het najaar van 2020 graag scholen bezochten die er in geslaagd zijn om door de inzet van onderwijsassistenten en/of andere vormen van rol- en taakdifferentiatie binnen het team - de werkdruk te verlagen en het werkgeluk verhogen. Scholen die zich hier in herkenden, konden zich via onze LinkedIn pagina of onze emailadressen aanmelden. Elf scholen en/of schoolbesturen hebben zich vervolgens bij ons aangemeld, en na een oriënterend gesprek over hun visie en werkwijze rondom taakdifferentiatie, bleek een (digitaal) bezoek tijdens de duur van het onderzoek praktisch haalbaar en passend op vijf van deze scholen.

\subsubsection{Documenten analyse en schoolbezoeken}

Per case is begonnen met het opvragen en evalueren van recente school- en jaarplannen en aanvullende documenten voor een beeld van het formele beleid ten aanzien van de inzet van het personeel.

De schoolbezoeken vonden vervolgens vier keer online plaats vanwege de maatregelen met betrekking tot de COVID19 pandemie. Eén schoolbezoek vond plaats in januari 2020 en kon zodoende nog op locatie plaatsvinden voor de intelligente lockdown van voorjaar 2020 begon, waarbij de scholen werden gesloten. De andere vier schoolbezoeken vonden allemaal plaats nadat de scholen de intelligente lockdown en de zomervakantie 2020 ruimschoots achter te rug hadden. De online en offline bezoeken bestonden uit een interview met in ieder geval de schoolleider, en in de meeste gevallen nog aangevuld door interviews met andere teamleden om meerdere perspectieven op de visies en werkpraktijken van de school te includeren. Een overzicht van de databronnen is te vinden in Tabel 4.1.

\subsubsection{Opbouw van de resultaten}

In paragraaf 4.5 geven we een compacte en unieke beschrijving van de vijf scholen in de vorm van vijf portretten. Hierin is de visie en werkwijze van de school ten aanzien van teamgericht werken en taakdifferentiatie beschreven op basis van de bestudeerde documenten en de schoolbezoeken, met de nadruk op de kenmerken die deze scholen onderscheiden van andere scholen uit de studie. Paragraaf 4.6 beschrijft vervolgens de bevindingen uit de

\footnotetext{
${ }^{13}$ https://www.linkedin.com/in/anders-organiseren-in-po-teams-b89561194/

14 https://didactiefonline.nl/artikel/minder-druk-meer-geluk
} 
schoolbezoeken. In paragraaf 4.7 geven we een samenvatting van de rapportage op basis van de belangrijkste bevindingen van deze deelstudie.

\section{Tabel 4.1 Casenummers met informatie over de afgenomen schoolbezoeken}

\begin{tabular}{|c|c|c|c|c|}
\hline Case & Geïnterviewden & Periode & Waar? & Andere bestudeerde informatie \\
\hline School 1 & $\begin{array}{ll}\text { - } & \text { Schoolleider } \\
\text { - } & 5 \text { leden onderwijsteam } \\
\text { onderbouw } \\
\text { - } 5 \text { leden expertteam ICT en } \\
\text { techniek }\end{array}$ & $\begin{array}{l}\text { Januari } \\
2020\end{array}$ & Op school & $\begin{array}{ll}\text { - } & \text { Jaarplan 2019-2020 } \\
\text { - } & \text { Werkverdelingsplan 2019-2020 } \\
\text { - } & \text { Schoolformatieplan 2019-2020 } \\
\text { - } & \text { Groeidocument "Werken vanuit een } \\
& \text { Teamgecentreerde } \\
\text { OrganisatieStructuur (TOS)" }\end{array}$ \\
\hline School 2 & $\begin{array}{l}\text { - Directie: directeur en } \\
\text { adjunct-directeur }\end{array}$ & $\begin{array}{l}\text { November } \\
2020\end{array}$ & Online & $\begin{array}{ll}\text { - } & \text { Kwaliteitshandboek 2019-2020 } \\
\text { - } & \text { Schoolgids 2019-2020 } \\
\text { - } & \text { Schoolplan 2019-2023 }\end{array}$ \\
\hline School 3 & $\begin{array}{l}\text { - } \quad \text { Een van de twee } \\
\text { schoolleiders } \\
\text { - } 2 \text { leraren: } 1 \text { in de rol van } \\
\text { leerteamvoorzitter en } 1 \text { in } \\
\text { de rol van coach zij- } \\
\text { instromers en nieuwe } \\
\text { leraren }\end{array}$ & $\begin{array}{l}\text { November } \\
2020\end{array}$ & Online & $\begin{array}{ll}\text { - } & \text { Schoolgids 2020-2021 } \\
\text { - } & \text { Strategisch beleidsplan 2018-2022 }\end{array}$ \\
\hline School 4 & $\begin{array}{ll}- & \text { Schoolleider } \\
\text { - } & \text { Onderwijsregisseur en } 2 \\
& \text { intern begeleiders }\end{array}$ & $\begin{array}{l}\text { November } \\
2020\end{array}$ & Online & $\begin{array}{l}\text { - } \quad \text { HRM-strategie 2020-2022 } \\
\text { - } \quad \text { Schoolplan 2019-2023 }\end{array}$ \\
\hline School 5 & $\begin{array}{l}\text { - } \quad \text { Schoolleider, intern } \\
\text { begeleider, leraar unit 1/2 } \\
\text { (kleuters), pedagogisch } \\
\text { medewerker }\end{array}$ & $\begin{array}{l}\text { Januari } \\
2021\end{array}$ & Online & $\begin{array}{ll}\text { - } & \text { Schoolgids 2020-2021 } \\
\text { - } & \text { Schoolplan 2019-2023 }\end{array}$ \\
\hline
\end{tabular}

\subsection{Vijf portretten van scholen}

Vooruitlopende op paragraaf 4.6 worden in deze paragraaf portretten geschetst van de vijf scholen die aan dit deelonderzoek deelnamen, met een beschrijving van de werkwijzen in het kader van taakdifferentiatie en teamgericht werken. Voor elke school wordt geschetst welke aanleiding zij hadden om over te gaan op het anders organiseren van het teamwerk, welke nieuwe werkwijzen zij hebben gekozen, welke rollen zij verdelen en door wie deze rollen worden uitgevoerd (leraren, onderwijsassistenten of andere professionals), en wat de aanpak van de school uniek maakt.

\subsubsection{School 1}

School 1 geeft onderwijs aan een 450-tal leerlingen, waaronder vrijwel geen leerlingen zijn met een leerlingengewicht. De ouderpopulatie kenmerkt zich door hoogopgeleide ouders en zelfstandige ondernemers. De school is gevestigd aan de rand van een dorp in een landelijke omgeving, in een wijk waarin voornamelijk vrijstaande huizen en 2-onder-1kaphuizen staan. Het onderwijs wordt gegeven door een team van zo'n 35 professionals (40\% man) waarvan het merendeel al langere tijd op school 1 werkt, en waarvan een groot deel full time werkt.

\section{De start van een nieuw begin}

In 2016 stond school 1 voor de uitdaging om van twee locaties terug te gaan naar één. Ondanks het feit dat beide locaties voorheen formeel tot dezelfde school behoorden, hadden zich twee teamculturen ontwikkeld die nu moesten worden samengevoegd. Daarnaast stond de school op het punt een nieuw schoolplan te ontwikkelen en flink te investeren in materieel en ruimte. Net voor deze veranderingen in gang werden gezet, werd de huidige schoolleider aangesteld. Omdat de nieuwe schoolleider enthousiast was over het werk van een onderwijsonderzoeker over teamgericht werken, heeft hij deze onderzoeker uitgenodigd om een bijeenkomst hierover te komen verzorgen aan het 
team. In het werk van deze onderzoeker leken alle uitdagingen samen te komen. De bijeenkomst werkte als katalysator, en het team kon vervolgens gezamenlijk de visie van de school herformuleren en hier gelijk concrete ambities aan verbinden voor de vier jaren die zouden volgen. Stapsgewijs werd een nieuwe organisatiestructuur vormgegeven en ingevoerd. Het nieuwe schoolgebouw was in aanbouw en al deze gebeurtenissen samen vormden de start van een nieuw begin.

Het vinden en uitstippelen van een nieuwe weg heeft een aantal jaren gekost, maar de eerste opbrengsten van teamgericht werken werden kort na de start al ervaren. Dat gaf het team een boost verder te ontwikkelen. In de kern heeft het schoolteam een werkwijze gevonden waarin zoveel mogelijk gewerkt wordt op basis van intrinsieke motivatie en dit geldt zowel voor het onderwijs dat gegeven wordt aan leerlingen, als voor de werkwijze van het team zelf. Leerlingen worden begeleid om vanuit intrinsieke motivatie te werken aan vaardigheden die zij nodig hebben om een duurzame plek in de maatschappij te verwerven. Leraren moesten weer maximale professionele ruimte krijgen en innemen om hun werk uit te voeren en de mogelijkheid krijgen om geïnformeerd en doordacht beslissingen te kunnen nemen.

\section{Huidige werkwijze: bouwleerkrachten, expertteams en een GOED gesprek}

Het schoolteam bestaat uit 3 verschillende onderwijsteams. Binnen deze teams is een deel van de leraren aangewezen als groepsleerkracht. Deze leraren zijn verantwoordelijk voor een van de groepen, vormen het aanspreekpunt voor ouders en leerlingen. Daarnaast zijn, per onderwijsteam, meerdere leraren en een leraarondersteuner aangewezen als bouwleerkracht. Zij hebben geen groepsverantwoordelijkheid, maar dragen wel zorg voor de leerlingen in de hele bouw. Zij ondersteunen de groepsleerkrachten door onder andere het onderwijs te ontwikkelen, groepjes kinderen te begeleiden, de groep over te nemen als nodig, de schoolkrant te coördineren, en de leerpleinen te coördineren. Hoewel zij breed inzetbaar zijn binnen het team, wordt de rol van de bouwleerkrachten steeds meer specialistisch. Binnen elk onderwijsteam is één van de leraren aangewezen als 'procesbegeleider'. Deze procesbegeleider kijkt voortdurend met de helicopterview naar het team en heeft daartoe altijd de volgende vragen in het achterhoofd:

$>\quad$ Wat speelt er binnen het team?

$>\quad$ Wat is er nodig?

> Hoe kunnen we dit team (nog meer) de ruimte geven?

De procesbegeleiders zijn opgeleid om deze rol te kunnen uitvoeren en deze rol is dan ook anders dan die van een bouwcoördinator of teamleider. Waar een teamleider 'leidt', stelt een procesbegeleider zich meer coachend op. Hij of zij stelt de kritische vragen en begeleidt het team tot de kern te komen en te blijven werken naar de visie van de school.

Elk onderwijsteam functioneert zelfstandig en is beslissingsbevoegd. Elk team heeft eigen verantwoordelijkheid in het verdelen van de taken, wat betekent dat men goed van elkaar moet weten wat iedereen wil en kan. Dit gaat diep, het team moet komen tot de kern van ieders ideeën over wat goed onderwijs inhoudt, over wat de rol van de leraar is en over hoe de ontwikkeling van kinderen verloopt. De teams hebben de afgelopen jaren dan ook geïnvesteerd in het leren voeren van gesprekken om tot deze basis te komen. Als ieders visie, talenten en verbeterpunten eenmaal op tafel liggen, is de basis voor goed teamwerk gelegd. De meeste gesprekken over de taken en rollen vinden dan ook in teamverband plaats, en niet (alleen) een-op-een met de schoolleider.

Naast de onderwijsteams zijn er op school expertteams, die elk zorg dragen voor een onderwijsinhoudelijk thema. Namelijk (1) ICT, wetenschap en techniek, (2) pedagogisch handelen, (3) didactisch handelen, en (4) betekenisvol thematisch werken. Binnen het betreffende thema ontwikkelt een expertteam kennis, ontwikkelen ze op basis daarvan het onderwijs met betrekking tot dit thema, en coachen ze leraren binnen het gehele schoolteam. Deelname aan een expertteam gaat op basis van interesse, maar voorwaarde is wel dat elk onderwijsteam vertegenwoordigd is in de expertteams om kennis te kunnen delen en vragen te kunnen ophalen. Expertteams zijn op school 1 niet beslissingsbevoegd. De bevoegdheid om iets met de ontwikkelde kennis te doen, ligt bij de onderwijsteams. Dat betekent dat expertteams de tijd en ruimte hebben om expertise op te bouwen, over te dragen en te ondersteunen, zonder daarbij de druk te voelen dat dit voor elke bouw toepasbaar moet zijn. Deze toepassing gaat namelijk geheel in overleg met de verschillende onderwijsteams. Deze werkwijze maakt dat deelname aan een expertteam een vorm van professionele ontwikkeling is en dat was ook een belangrijk argument voor school 1 om expertteams op deze wijze vorm te geven. 
Andere, meer specialistische rollen die aan een van de teamleden zijn toegedicht, zijn: een event manager, ICTcoördinator, intern begeleider, iemand die zorgt voor het voeren van gesprekken met (potentiele) nieuwe ouders, coach groepsprocessen in de klas (met betrekking tot gedrag van leerlingen), begeleiding van nieuwe collega's, basisschoolcoach, coach hoogbegaafdheid, coördinatie wetenschap en techniek. Op dit moment is het de schoolleider die leraren over de teams verdeeld, en dit gebeurt met name op basis van intrinsieke motivatie. Het begint allemaal bij een goed gesprek en dat gesprek is er dan ook gedurende het hele jaar. Tussendoor, in de wandelgangen en in de pauzes. Gesprekken op informele basis. Daarnaast is er 1 keer per jaar een officieel 'GOED' gesprek tussen schoolleider en teamlid om zijn/haar wensen te bespreken. Dit GOED gesprek is een alternatief voor het functioneringsgesprek. De wens is om in de toekomst nog meer de talenten en kwaliteiten van elke professional naar boven te laten komen. Daarnaast is de ambitie van het team om binnenkort een stap verder te zetten richting teamgericht werken, door ook de GOED-gesprekken met het gehele onderwijsteam te voeren en er een teamontwikkelgesprek van te maken.

Of het nu gaat om het aantrekken van nieuwe professionals, of het verdelen van taken onder het bestaande team: er wordt binnen school 1 zoveel mogelijk gestuurd naar werkgeluk. Om alle professionals zo goed mogelijk te laten functioneren moet ieder maximaal hun professionele ruimte innemen, werken op basis van intrinsieke motivatie en plezier hebben in het werk. Dat komt enerzijds tot uiting in het verdelen van taken naar talent en expertise. Anderzijds komt dit tot uiting in het scheppen van voorwaarden om iemand zijn/haar taken zo goed mogelijk uit te laten voeren. Schoolleider: "Als je als leraar jonge kinderen hebt, dan zeg ik: we bekijken of je op 1 van de dagen zelf je kinderen uit school kunt halen om 15 uur." Duurzame inzetbaarheid wordt dus breed geïnterpreteerd.

\section{Wat maakt school 1 uniek?}

Intrinsieke motivatie als uitgangspunt voor de werkwijze van het team en het onderwijs aan de leerlingen; Expertteams die thematisch kennis ontwikkelen, advies geven aan onderwijsteams en niet beslissingsbevoegd zijn;

Onderwijsteams die bestaan uit groepsleraren en bouwleraren (zonder groepsverantwoordelijkheid); De rol van procesbegeleider.

\subsubsection{School 2}

School 2 is gevestigd in een grote stad in de Randstad en geeft onderwijs aan een kleine 200 leerlingen. School 2 is een van de zwaarste scholen van Nederland als je kijkt naar de populatie: er heerst veel armoede en er zijn veel eenoudergezinnen. Het schoolteam bestaat voor een groot deel uit professionals die al lang werkzaam zijn op deze school. Ze kennen de school en de leerlingpopulatie door en door.

\section{De start van een nieuw begin}

Aan de start van de verandering werkte de school al conform de methode van stichting leerKRACHT (sinds 2013). Maar de manier van werken kenmerkte zich toen als een heel rigide opbrengstgerichte cultuur waarin de resultaten leidend waren. Er werd gewerkt aan de hand van het directe instructiemodel en de methode zelfstandig werken.

De start van het anders gaan organiseren is ingegeven door het team van de toenmalige onderbouw. Onder de onderbouwleraren heerste het gevoel dat het kleuteronderwijs niet voldoende recht deed aan kinderen. De resultaten bleven achter en er was onder veel kinderen weinig groei te zien (negatieve citotoetsen, slechte resultaten, geen stijging van de woordenschat ondanks alle VVE-programma's). Met andere woorden, het team had het idee dat wat zij deden niet bijdroeg aan de ontwikkeling van kinderen. De wens was om een rijkere leeromgeving te creëren en meer vanuit spel te handelen, omdat spel leidend is om jezelf te ontwikkelen. Om dit te bewerkstelligen is de overstap gemaakt van homogene groepen naar heterogene groepen en zo ontstond 'unit 1'. Het team van unit 1 werd gecoacht in spel en ook in ontwikkelingsgericht werken. Er werd gewerkt met 17 ontwikkelingslijnen vanuit KIJK en observeren stond vanaf dat moment centraal. Hierdoor kon elk kind op zijn/haar niveau worden ondersteund wat leidde tot zichtbaar meer groei. Toen deze kinderen naar groep 3 gingen, ontstond er een knelpunt: de ontwikkelingslijnen moesten in een 'jaarklassensysteem' geperst worden en dat ging niet. Leraren benoemden dat het lastig was deze ontwikkelingslijnen om te schrijven naar groepsplannen en ze hadden het gevoel vast te lopen in differentiatie. De schoolleiding heeft alle wensen van het team visueel gemaakt en het idee ontstond om het onderwijs op de gehele school anders te organiseren. Het schoolteam kreeg de ruimte om samen veel andere scholen te bezoeken om inspiratie op te doen en te ervaren wat voor onderwijs zij zelf wilden geven. Na deze bezoeken gaf het team te willen gaan werken in units. De knoop werd doorgehakt en er is eerst zonder enig kader geëxperimenteerd. Heel bewust, om 
het team zelf dit kader te laten vormgeven (2017). Vanuit de schoolleiding is het team vervolgens begeleid in samenwerken, kennisdelen, in het ervoor zorgen dat je kennis omzet in vaardigheden. Daarbij heeft ondersteuning van stichting LeerKRACHT geholpen om wel efficiënt te blijven werken.

\section{Huidige werkwijze: specialisten van buiten en maximale differentiatie}

Het schoolteam werkt in 4 units, en elke unit bestaat uit twee leerjaren. De leraren die werkzaam zijn in een unit, zijn samen verantwoordelijk voor het geven van onderwijs aan alle kinderen. Het hele unitteam draagt de verantwoordelijkheid voor de ontwikkeling van alle kinderen binnen de unit. Deze manier van werken geeft kinderen letterlijk en figuurlijk de ruimte om zich vrij door de unit te bewegen en daardoor biedt deze manier van werken ruimte tot differentiatie. Dit past bij de focus van school twee om continu aandacht te hebben voor de ontwikkeling van talenten van kinderen. Om dit te kunnen bieden, is het volgens school 2 cruciaal om kinderen de ruimte te bieden voor nieuwsgierigheid, experts in huis te halen die talent kunnen herkennen en het een podium kunnen geven of kinderen op de route kunnen zetten dit talent verder te ontwikkelen en maximaal te kunnen ontwikkelen.

In elke unit zijn naast leraren ook onderwijsassistenten werkzaam. Binnen een unitteam is er zo min mogelijk hiërarchie; iedereen is gelijk. En dat betekent dat alle taken door een leraar of door een onderwijsassistent uitgevoerd kunnen worden. Startpunt is namelijk: waar is iemand goed in en wat vindt hij/zij leuk om te doen? De focus ligt op iemands kracht en vervolgens speelt de vraag: wat wil iemand ontwikkelen? Er wordt heel bewust niet gedifferentieerd in functies. In plaats daarvan hanteert de school een groeidocument waarin, op basis van de visie van de school, staat verwoord wat je in basis moet kunnen enop zak moet hebben als je op deze school wilt komen werken. Daarnaast staat hierin verwoord waarin je kunt groeien. Teamleden kunnen vervolgens - ongeacht opleidingsachtergrond - zichzelf scoren op deze bekwaamheden van starter tot expert om als team deze groei bij te houden en er zelf de regie in te kunnen nemen. Deze manier van werken maakt dat de verdeling van rollen over tijd kan veranderen, en dat er veel autonomie ligt bij de units als het gaat om het uitstippelen van routes voor ontwikkeling. Om als school wel één lijn te trekken en als geheel schoolteam te werken aan dezelfde doelen, heeft het team gezamenlijk jaarplandoelen opgesteld. Deze doelen zijn voor alle units gelijk en worden ook door iedereen gedragen. De weg naar het behalen van deze doelen kan elke unit zelf bepalen.

Naast leraren en onderwijsassistenten zijn er veel andere professionals werkzaam binnen de units. Namelijk: vrijwilligers, specialisten kunst, muziek, gym, gelijke kansencoördinator, IB'ers, schoolmaatschappelijk werk, diëtisten, logopedisten. Belangrijk speerpunt is ook derdejaars studenten te betrekken. Dit zijn voornamelijk pabo-studenten en één student heeft een andere, specialistische, achtergrond. Er is bewust voor gekozen deze expertise van buiten het team leraren en onderwijsassistenten te laten komen. Gezamenlijk genereren deze experts namelijk een kwalitatief breed en beredeneerd aanbod, waarin een ieder vanuit de eigen expertise onderwijs verzorgt aan de leerlingen. De structurele inzet van deze specialisten biedt de onderwijsprofessionals (leraren en onderwijsassistenten) de ruimte zich te focussen op de ontwikkeling van de leerlingen, en op het verzorgen van onderwijs op maat. Tegelijkertijd biedt deze hulp en aanwezige expertise ook de mogelijkheid kinderen maximaal effectieve ondersteuning te bieden waar dat nodig is en talenten verder te laten ontplooien.

Tot slot hebben ouders een belangrijke rol binnen de school. Taken die zij uitvoeren zijn: het bieden van begeleiding aan buitenactiviteiten, het bieden van ondersteuning bij het lezen in de units, en zij doen taken die op dat moment voor handen is. De communicatie met de ouders over het onderwijsaanbod is sterk. Ouders worden op deze school gezien als educatief partners en leerkrachten zetten zich hier maximaal voor in.

\section{Wat maakt school 2 uniek?}

Unitonderwijs en indeling van de ruimte op school;

Structurele inzet van professionals met een andere expertise dan leraren en onderwijsassistenten;

Expliciete aandacht voor opleiden en duurzame inzetbaarheid van onderwijsassistente;

Primair aandacht voor de ontwikkeling van talenten van leerlingen. 


\subsubsection{School 3}

School 3 is te typeren als een grote dorpsschool, zoals de schoolleider zelf formuleert. De kenmerken van de leerlingpopulatie zijn gemiddeld te noemen (in niveau zijn er uitschieters naar zowel de bovenkant als de onderkant) en de school ligt in een dorp in het midden van Nederland. Het leerlingaantal van de school schommelt rond de 650 leerlingen en er zijn 50 teamleden werkzaam om het onderwijs te verzorgen.

\section{De start van een nieuw begin}

School 3 heeft in 2016 een nieuwe beweging ingezet samen met andere scholen binnen de stichting. De nieuwe voorzitter van het bestuur van de stichting had een uitgesproken onderwijsvisie en heeft alle scholen binnen de stichting meegenomen een nieuwe weg in te slaan. Deze nieuwe weg betrof het compleet kantelen van de organisatie: Het ambacht van de leraar moest weer centraal komen te staan, zodat leren nog meer centraal kon komen te staan. Deze verandering was een grote omschakeling en is gefaseerd doorgevoerd. Momenteel wordt dan ook nog gesleuteld aan het concept, maar de kern ervan staat. Het team van school 3 is in dit traject begeleid door een extern bureau en uiteindelijk is op basis van de vijf pijlers uit het High Performance Schools-model de nieuwe structuur ontworpen. Deze vijf pijlers zijn:

> Het belang van een lange termijn focus: iedereen op school weet wat er gedaan moet worden, de visie is overal zichtbaar en wordt keer op keer benoemd. Er is een duidelijk plan dat door het hele team gedragen wordt.

> Het belang van effectief leiderschap op alle lagen.

> Het belang van het ontwikkelingen van de kwaliteiten van de medewerkers

> Het belang van openheid en actiegerichtheid: er wordt gezorgd voor een cultuur waarin dat gewaarborgd wordt.

> Het belang van continue verbetering en innovatie: het uitgangspunt is 'veranderen gebeurt de hele dag door en jij bent de verandering'.

\section{Huidige werkwijze: hiërarchie eruit en vooral binnenshuis expertise ontwikkelen}

Leerlingen zijn gegroepeerd in een klas. De school heeft er bewust voor gekozen geen combinatieklassen te maken. Er wordt op school 3 gewerkt aan de hand van EDI-instructie en uitgangspunt van deze instructiemethode is dat het geven van instructie het beste gaat als je een homogene groep kinderen van dezelfde leeftijd hebt, al is er altijd heterogeniteit van niveau. Vanuit dit concept zijn leraren op school 3 terughoudend met versnellen van de stof. De groep leert met elkaar en op deze manier wordt ervoor gezorgd dat iedereen in de klas op dit niveau meegetrokken wordt. Een leerling die ergens in uitblinkt, kan een andere leerling daarin meenemen.

Administratie wordt op school 3 tot een minimum beperkt. Er zijn geen groepsplannen meer. In plaats daarvan wordt er 'slim' gegroepeerd zodat leerlingen optimaal met en van elkaar leren.

Om het ambacht van het leraarschap weer centraal te stellen, is (bijna) alle hiërarchie uit het team gehaald: van een oude structuur met veel coördinerende functies (directeur, adjunct directeur, bouwcoördinatoren, intern begeleiders) naar een team dat is gebouwd op expertises, georganiseerd in leerteams bestaande uit 6-8 collega's. Iedereen binnen het team is gelijk. Er wordt dan ook niet gekeken naar de opleidingsachtergrond van professionals, maar naar de expertise die iemand meebrengt en de mate waarin iemand de motivatie heeft zichzelf te blijven ontwikkelen. Er zijn 2 schoolleiders en dat is de enige andere functie die er binnen het team bestaat naast het 'leraarschap'.

De leerteams doen samen 3 dingen: (1) leerlingbespreking en groepsbespreking inclusief bespreking van de onderwijsresultaten, zodat je met elkaar een team een kennisbasis opbouwt. (2) Lesson studies: deze methodiek wordt niet helemaal volgens de letter uitgevoerd, maar de strekking ervan wel, en dat is: samen met elkaar over je les praten. Er wordt actief bij elkaar gekeken om elkaar feedback te geven. Elk leerteam heeft 1 ambulante dag per week. Als er bij elkaar gekeken moet worden (al is 'moeten' hier niet de juiste formulering), kan iemand anders de klas even overnemen. Deze ambulante dag kan overigens ook voor andere zaken worden gebruikt, zoals het zoeken van literatuur of het uitdenken van een plan. (3) Lange termijnonderzoeken volgens data-teammethode. Zie volgende alinea's voor meer informatie over de datateamspecialist in elk leerteam.

In elk leerteam is een aantal expertises terug te vinden, namelijk: (1) voorzitter, (2) rekenspecialist, (3) taalspecialist, (4) burgerschapspecialist, en (5) data-teamspecialist. Bijna alle leraren hebben een speciale rol in het leerteam, maar 
gezien de grootte van het gehele schoolteam, is dit niet noodzakelijk. Wel draagt iedereen vanuit zijn/haar kracht en expertise bij aan de organisatie van de school. De visie van de school is daarin leidend en deze visie zorgt er dan ook voor dat de leerteams in hoofdlijnen allemaal aan dezelfde speerpunten werken. Binnen deze speerpunten heeft elk leerteam alle vrijheid en ook de weg er naartoe kan een leerteam zelf bepalen. Om er voor te zorgen dat de leerteams van elkaar blijven leren en ook op de hoogte zijn van elkaars werk, wordt eens in de paar maanden een moment georganiseerd waarin de leerteams zichzelf aan de andere teams presenteren.

De school kiest ervoor zoveel mogelijk expertise zelf te ontwikkelen. Door met $z^{\prime} n$ allen steeds meer kennis te verwerven, kunnen steeds vaker leerlingspecifieke situaties binnenschools worden opgelost of bediend. Voor deze manier van werken is een onderzoekmatige blik nodig op al het werk dat er wordt uitgevoerd. Dit is ook de reden dat een van de vastomlijnde rollen in elk leerteam de 'datateamspecialist' is. Zodra er iets speelt in de klas, of wanneer er iets wordt gesignaleerd door een teamlid dat aandacht verdient, wordt gezamenlijk kennis verworven en onderzoek gedaan samen met de datateamspecialist, om uit te zoeken welke overwegingen er moeten worden gemaakt en welke oplossing bij dit specifieke probleem past. Tot slot is de functie van intern begeleider in school 3 door ontwikkeld tot de rol 'kwaliteitscoördinator', uitgevoerd door een leraar. Voorheen was de intern begeleider de rechterhand van de leraar: als een leraar tegen een probleem of zorgvraag aan liep, raadpleegde hij/zij de intern begeleider. Maar omdat in de nieuwe structuur alle leraren worden gestimuleerd zelf kennis te genereren wanneer en dergelijke vraag opkomt, voegde deze oude invulling van de IB-functie niet genoeg meer toe. In plaats daarvan zijn er drie kwaliteitscoördinatoren ( $K C^{\prime}$ ers) gekomen die op drie vlakken de kwaliteit van het onderwijs bewaken: de kwaliteit van de data (de KC'er kijkt schoolbreed naar alle beschikbare data om in de gaten te houden hoe de school functioneert), de kwaliteit van het onderwijs (de KC'er legt groepsbezoeken af om het functioneren van leraren te monitoren) en de kwaliteit van de zorg en ondersteuning van de leraren. De KC'er gebruikt de leerteams om te de-escaleren: zodra er een probleem wordt gesignaleerd, wordt dit in het betreffende leerteam besproken.

\section{Wat maakt school 3 uniek?}

) De manier van werken is stichtingbreed ingevoerd en is door samenwerking van de verschillende scholen binnen de stichting tot stand gekomen;

Er wordt gewerkt in subteams. In elk subteam (leerteam) is een aantal vastomlijnde rollen terug te vinden; Leerlingen zijn op leeftijd gegroepeerd in homogene klassen;

Werken op basis van kennis en onderzoek;

Intern begeleiderfunctie is doorontwikkeld tot de rol 'kwaliteitscoördinator'.

\subsubsection{School 4}

School 4 kenmerkt zich als een school met een leerlingpopulatie van gemiddeld niveau en is gelokaliseerd in een nieuwbouwwijk die nog in aanbouw is, in een stad in het noorden van het land. Er zitten momenteel meer dan 700 leerlingen op school 4 die onderwijs krijgen van zo'n 50 professionals.

\section{De start van een nieuw begin}

Toen de schoolleider begin 2010 op school 4 kwam te werken, betrof de leerlingpopulatie 20 leerlingen. Op dat moment werkte de school al op basis van drie pijlers: welbevinden, leren en ervaren. Deze pijlers golden zowel voor het georganiseerde onderwijs voor de leerlingen, als voor de werkwijze binnen het team. De schoolleider heeft deze werkwijze verder doorgezet en uitgewerkt door in beginsel te gaan werken aan geven van meer zelfstandigheid aan leerlingen. Dit werd gedaan aan de hand van de ZWING-methode, wat staat voor Zelfstandig Werken in Niveaugroepen. Inmiddels vormt het "ZWING'en nog steeds een prominent onderdeel van het onderwijs, en is de werkwijze op basis van de pijler 'Leren' verder uitgewerkt.

Vanwege verschillende redenen is de school in 2016 overgestapt naar een ander organisatiemodel, waarin de schoolleider niet meer de verantwoording had over alles. Enerzijds werd door hem en het team vastgesteld dat het team weinig eigenaarschap had over het reilen en zeilen op school, terwijl de gedeelde visie was dat eigenaarschap binnen het team wel gewenst was. Anderzijds groeide de school in rap tempo wat het onmogelijk maakte dat de schoolleider alles onder zijn verantwoordelijkheid liet vallen. Deze 'overstap' ging echter niet van de een op de andere dag. Een nieuw organisatiemodel is ontwikkeld waarin teamleden gingen werken op basis van ambitie, talent en het doen van werk waar je goed in bent. Want als je je leerlingen opleidt om zelf op deze manier te werken, moet dit weerspiegeld zijn in de werkwijze van het team, luidde de redenering. 
Deze ontwikkeling viel samen met een ontwikkeling op stichtingniveau. De stichting waar de school onder valt, heeft sinds 2015 het HR-beleid doorontwikkeld naar een beleid waarin talent en expertise centraal staan. Hoewel school 4 zelf de weg al was ingeslagen en een eigen werkwijze had ontwikkeld, hielp het dat zij konden aanhaken bij de plannen van de stichting.

\section{Huidige werkwijze: een strakke structuur en focus op ambities}

Het onderwijs is georganiseerd op basis van 3 pijlers: Leren, Ervaren en Welbevinden. Deze pijlers reflecteren de visie van de school. Kinderen ontwikkelen zich het best wanneer zij gezien worden, zich gekend en gewaardeerd weten en zich prettig voelen, zo stelt de school. De 3 pijlers zijn in elk aspect van het onderwijs terug te vinden: in de inhoud van het onderwijs, maar ook de vorm waarin het gegeven wordt en in de manier waarop de professionals onderling te werk gaan. Voorbeeld: er wordt gewerkt met een filosofie om kinderen respectvol met elkaar om te leren gaan en op constructieve manier met elkaar in gesprek te gaan, maar ook met respect naar jezelf te leren kijken, in te leren schatten waar je goed in bent en daadwerkelijk gebruik te maken van deze krachten. Deze filosofie wordt doorgetrokken in de manier waarop ouders worden betrokken bij het onderwijs van hun kind(eren), en in de manier waarop het pedagogisch klimaat vorm krijgt. Door middel van 'Verbindende communicatie' en het voeren van waarderende gesprekken (op basis van de Appreciative Inquiry methode) worden gesprekken tussen professionals onderling gevoerd, worden gesprekken met leerlingen gevoerd en met ouders.

Het schoolteam is verdeeld in leerteams, bestaande uit gemiddeld 12 collega's en elk team wordt geleid door een voorzitter. Daarnaast is een zevental specialismen onderscheiden, uitgevoerd door collega's verspreid over de leerteams. Te weten: rekenen, taal, gedrag, cultuur, zorg en ondersteuning (dat aangestuurd wordt door intern begeleiders), welbevinden, het jonge kind. De specialisten dragen zorg voor alle leerteams, maar zijn niet in elk leerteam vertegenwoordigd. Daarnaast zijn de specialisten allemaal HBO+ of universitair geschoold en organiseren zij zichzelf in werkgroepen, zowel binnenschools als bovenschools met specialisten van andere scholen binnen de stichting. Deze werkgroepen komen eens per twee maanden samen om van elkaar te leren en 'te halen en brengen' zoals het door de professionals zelf wordt geformuleerd. De werkgroepen hebben hun eigen speerpunten, maar deze speerpunten liggen altijd in lijn met de jaardoelen. Naast de vastomlijnde leerteams is er voor alle professionals de mogelijkheid een aanvullende ofnieuwe rol op zich te nemen. Op basis van het schoolplan en het jaarplan wordt tegen het einde van het schooljaar (mei) een vacaturemuur gemaakt. Op deze muur kunnen teamleden, gerelateerd aan het schoolplan en de jaarplanpunten die zijn opgenomen in het vierjarig schoolplan, speerpunten formuleren voor het komende jaar. Ook kunnen zij hier aangeven waaraan zij graag zelf zouden willen bijdragen en waar volgens hen accent op moet komen te liggen.

'Boven' deze leerteams hangt de regiegroep, waarin de voorzitters van de leerteams en de onderwijsregisseur plaatsnemen. Samen houden zij in de gaten dat er gedurende het jaar aan het jaarplan gewerkt blijft worden en maken zij plannen om ervoor te zorgen dat het schoolteam aan het einde van het jaar kan laten zien wat het heeft beloofd. De onderwijsregisseur monitort de onderwijskundige inhoud van het onderwijs. Dit houdt in dat zij monitort wat er aan onderwijs gegeven wordt, dat ze de doorgaande leerlijnen in de gaten houdt, ervoor zorgt dat er gewerkt wordt aan de speerpunten uit het jaarplan, en dat zij voortdurend afstemt met de groepen en met de MR. Dat de onderwijsregisseur deze onderwijskundige taken op zich neemt, geeft de schoolleider de ruimte vanuit helicopterview te kijken naar alles dat er op school gebeurt. Hij is eindverantwoordelijk en dat betekent dat alles dat er gebeurt op school langs hem gaat en hij altijd betrokken is bij de besluitvorming. De schoolleider organiseert en regelt onder andere het personeelsbeleid, de PR en de communicatie, en hij heeft zijn bovenschoolse verantwoordelijkheden. De onderwijsregisseur en de schoolleider hebben zeer regelmatig overleg.

Er wordt op school 4 gewerkt op basis van ambitie van medewerkers en dat betekent dat het functiebouwhuis is losgelaten. Ambitie vormt de rode draad door ieders taken. Dit kan betekenen dat iemand een andere weg in slaat, maar juist de ruimte om deze weg zelf uit te stippelen - samen met het team - is wat de stichting en school 4 zelf stimuleert onder medewerkers. Deze manier van werken vraagt veel openheid in het team en dus is er veel aandacht voor het uitwisselen van feedback, en het bespreken van ieders functioneren, wensen en ambities. Gesprekken hierover worden gevoerd in groepen van 5 medewerkers (en dus in principe niet meer een-op-een tussen de schoolleider en een medewerker, al kan dit altijd als een medewerker dit wenst), bestaande uit medewerkers die in hetzelfde leerteam werken, of uit medewerkers uit verschillende leerteams. Er is een vaste gesprekscyclus voor het voeren van deze 
gesprekken, die bestaat uit drie fasen: ambitie, reflectie en waardering. In de gesprekscyclus wordt enerzijds gereflecteerd op de werkwijze van individuen en krijgt elke professional de ruimte zijn/haar ambities uit te spreken, bij te stellen en vorm te geven. Anderzijds is dit het moment om als team de talenten en ambities bij elkaar te brengen.

Op school 4 wordt breed gekeken naar het begrip 'onderwijsondersteuning'. Ondersteuning wordt niet alleen bij onderwijsassistenten gezocht. De ambitie is om de leraren in de klas zelf de ondersteuning en zorg te kunnen laten bieden. Leraren met specialistische kennis kunnen deze inzetten voor het team. Juist zij kunnen worden vrij-geroosterd om andere collega's te ondersteunen. Niet voor niets worden de experts daarom binnen het schoolteam 'expertondersteuners' genoemd. Juist doordat je verschillende expertises ontwikkelt, ondersteun je elkaar.

\section{Wat maakt school 4 uniek?}

> Vanuit stichting aandacht voor ambities van medewerkers, functiebouwhuis is losgelaten;

> Specialismen verdeeld over leerteams heen; specialisten ondersteunen dus alle leerteams op het gebied van expertise;

) Bespreking van functioneren en ambities gebeurt in teamverband;

> Rol onderwijsregisseur;

> Vacaturemuur.

\subsubsection{School 5}

School 5 is te kenmerken als een school met een gemêleerde leerling- en ouderpopulatie, waarin een reële afspiegeling van de maatschappij terug te zien is. De school is gevestigd in het hart van een grote stad in het oosten van Nederland. Op school 5 wordt onderwijs gegeven aan zo'n 270 leerlingen, door 24 medewerkers die bijna allemaal vanaf het begin van de nieuwe werkwijze bij school 5 werkzaam zijn.

\section{De start van een nieuw begin}

Sinds 2014 heeft school 5 een nieuwe weg ingeslagen. Er lag op dat moment een plan voor de inzet van flexibele onderwijstijden. Om dit plan door te voeren, moest bekeken worden of deze manier van onderwijs geven passend was bij het huidige team. Het stichtingsbestuur heeft met alle medewerkers gesprekken gevoerd om te peilen in hoeverre dit het geval was. Een gedeelte van het team koos ervoor een meer passende werkplek binnen de stichting te zoeken. De huidige schoolleider werd aangesteld en nieuwe teamleden zijn geworven.

School 5 is onderdeel van een integraal kindcentrum en samen met de kinderdagverblijf en de BSO begonnen ze aan een nieuw schooljaar waarin de nieuwe organisatie al doende vorm kreeg door elke dag te bespreken hoe het gaat en wat er anders en beter kan. Na een maand of zes kwam de onderwijsinspectie al langs, maar die zijn met het bestuur van de stichting in gesprek gegaan over de ontwikkelingen en plannen. School 5 kreeg vervolgens van zowel de inspectie als het stichtingsbestuur de ruimte om verder te ontwikkelen, mits elke stap goed beargumenteerd zou worden.

In de oude werkwijze zaten veel lagen in de organisatiestructuur, maar de wens was deze te minimaliseren. Inmiddels spreekt men van een platte organisatie waarbij de 5 uitgangspunten voor goed onderwijs van de overkoepelende stichting als leidraad voor de onderwijsorganisatie dienen. De jaardoelen van de school worden gezamenlijk met het team opgesteld, waardoor iedereen zich in deze doelen herkent en zich eraan committeert. De gezamenlijkheid wordt doorgetrokken naar de leerlingen: zij zijn samen met de leerkrachten verantwoordelijk voor het onderwijs. Er wordt op school 5 dan ook niet met rapporten gewerkt, maar met groeijournaals, waar de leerlingen mede verantwoordelijk voor zijn. De gesprekken met ouders en leerlingen worden groeigesprekken genoemd: driehoekgesprekken waarin het kind zelf vertelt wat het geleerd heeft, en wel of niet leuk vindt.

\section{Huidige werkwijze: sociocratisch vergaderen en nauwe samenwerking met pedagogisch medewerkers} Het schoolteam is opgedeeld in units waarin twee leerjaren zijn samengevoegd. Binnen elke unit zijn subteams geformeerd, bestaande uit twee leerkrachten en een pedagogisch medewerker. 's Ochtends wordt er per unit aan de kernvakken van het onderwijs gewerkt in het eigen leerjaar, en 's middags werken de leerlingen van verschillende leerjaren (maar wel binnen de eigen unit) door elkaar aan verschillende, in hoeken opgestelde thema's. Elke unit heeft hiervoor twee lokalen naast elkaar beschikbaar waarvan de tussendeur wordt opengesteld. 
Per unit zijn de volgende werkdagen te verdelen onder de unitteamleden: 8 werkdagen voor de leerkrachten en 3 werkdagen voor de pedagogisch medewerker. Per unit blijft er dan 1 dag over die voor zogenoemde 'preparation time' kan worden gebruikt. Dit is tijd om lessen voor te bereiden, te overleggen, uit te wisselen, kortom: voor activiteiten die geen lessen en instructies geven beslaan. De teamleden geven aan alle kinderen van de gehele unit goed in het vizier te hebben, ondanks het feit dat zij de kinderen niet de hele dag in hetzelfde klaslokaal zien handelen. Drie paar ogen zien namelijk meer dan één paar en ook de verschillende achtergronden van leraren en pedagogisch medewerkers maakt dat elke professional andere dingen signaleert. Samen kom je zodoende tot een completer beeld van elke leerling.

De opdeling in units vraagt om goede samenwerking binnen die units, met een gezamenlijke verantwoordelijkheid voor de klassen. De communicatie binnen de units wordt door de teamleden als heel sterk ervaren, mede vanwege de korte lijntjes die ze onderling hebben. Teamleden vergaderen op sociocratische wijze, en er wordt in de verdeling van taken en rollen een beroep gedaan op ieders eigen verantwoordelijkheid, openheid en loyaliteit. Iemand die fulltime werkt, zit bijvoorbeeld in meer werkgroepen. Er is vanuit de school oog voor talent van de leerlingen en van de medewerkers. Iedereen heeft zijn of haar talent en wordt daar op ingezet. Op basis van individuele talentgerichte functioneringsgesprekken wordt aan het begin van elk schooljaar in grote lijnen bepaald wat ieders bijdrage wordt aan de gestelde jaardoelen. Binnen de unit worden taken verder verdeeld, dit gebeurt voor een groot deel op organische wijze. Dit betekent dat je op school 5 niet in elk unitteam dezelfde rollen terug ziet komen.

De pedagogisch medewerkers spelen een grote rol in het team van school 5 . Zij staan alleen voor de klas als het sociaal emotionele lessen betreft, of als er herinstructie van een reeds gegeven les nodig is. Er is bewust gekozen voor de inzet van pedagogisch medewerkers in plaats van onderwijsassistenten. De pedagogisch medewerkers werken namelijk ook op de voorschoolse en buitenschoolse opvang binnen het IKC waar school 5 onderdeel van uitmaakt, en zijn zodoende bekende gezichten voor de kinderen. Ook hebben de pedagogisch medewerkers veel contact met de ouders, waardoor ze bijvoorbeeld relatief veel informatie over de thuissituatie van de kinderen hebben. Zij kijken met een andere blik naar de leerlingen en zijn vanuit hun achtergrond nog meer gericht op het kind dan op de les en het onderwijs, zo geven verschillende teamleden aan.

Tot slot is school 5 te kenmerken als een school met een opvallend aannamebeleid als het gaat om de werving van nieuwe collega's. Hierbij wordt met name gelet op persoonlijkheid, en minder op opleidingsachtergrond. Op basis van literatuur stelt school 5 namelijk dat veel kennis en vaardigheden te verwerven zijn, en daar wordt schoolintern dan ook veel aandacht aan besteed. Persoonlijkheidskenmerken zijn daarentegen niet zomaar te veranderen. In praktijk betekent dit dat tijdens sollicitaties minder wordt gekeken naar bijvoorbeeld aanvullende certificaten of diploma's rondom het pabo-diploma of diploma pedagogisch medewerker. Veel belangrijker is het dat een kandidaat goed kan communiceren, samenwerken en compassie heeft voor de kinderen. Verbinden door middel van bijvoorbeeld de vrijdagmiddagborrel is ook belangrijk. Hierbij gaat het niet om het borrelen op zich, maar om de functie ervan: gezamenlijk stoom afblazen en samen lol maken. Kortom: er wordt gekeken naar de mate waarin iemand bij dit team past en mee kan ontwikkelen met zijn/haar collega's.

\section{Wat maakt school 5 uniek?}

Structurele inzet pedagogisch medewerkers;

Organische invulling van rollen en taken;

Werving op basis van (met name) persoonlijkheid;

Unieke organisatie van het onderwijs op het gebied van flexibele lestijden, dagindeling, tienercollege, en speerpunten t.a.v. passend onderwijs.

\subsection{Bevindingen op basis van de portretten}

Hieronder worden de bevindingen met betrekking tot de acht onderzoeksvragen beschreven. Bij het beschrijven van de resultaten is structurering aan de hand van de onderzoeksvragen aangehouden. 


\subsubsection{Hoe worden de rol- en taakverdeling binnen de (sub)teams vormgegeven?}

\section{Schoolteam en subteams}

Bij alle vijf de scholen is er naast een algemeen schoolteam ook sprake van subteams, zoals leerteams, onderwijsteams of units, die de verantwoordelijkheid dragen over het onderwijs voor een combinatie van twee à drie jaarklassen. Deze teams bestaan veelal uit groepsleraren en specialisten op het gebied van bijvoorbeeld taal, rekenen, muziek, kunst, cultuur, gedrag, burgerschap en andere onderwijsthema's. Eventueel worden deze subteams aangevuld met een voorzitter, pedagogisch medewerkers, zorgprofessionals, procesbegeleiders en onderwijsassistenten of andere ondersteuners (vrijwilligers, studenten). In sommige gevallen bestaan er naast deze teams nog expertteams (school 1), focusgroepen (school 2) of specialistennetwerken of werkgroepen (school 4) van professionals met een gedeeld specialisme, die bij elkaar komen om aan kennis- en onderwijsontwikkeling te doen op hun thema of collega's te coachen op dit thema.

$\mathrm{Er}$ is dus in algemene zin sprake van drie verschillende (sub)teams: het integrale schoolteam, multidisciplinaire teams met lesgevende taken (units, onderwijs- of leerteams, op basis van leerjaren) en monodisciplinaire teams (expertteams, focus- of werkgroepen, op basis van thema). In school 4 is er, naast leerteams en specialistennetwerken, ook sprake van een overkoepelende regiegroep, bestaande uit de voorzitters van de netwerken en de onderwijsregisseur. Deze groep monitort de voortgang op de jaardoelen.

De rollen binnen het schoolteam zijn overstijgend en vullen zodoende de units/leerteams en expertteams/specialistennetwerken aan. Dit zijn bijvoorbeeld gymleraren, conciërges, eventmanagers, coach zijinstromers en nieuwe leraren, managementassistenten en administratief medewerkers. Op school 1 is de rol van de administratief ondersteuner erg groot. Naast de 'reguliere administratieve taken' neemt de administratief ondersteuner veel werk uit handen van de leraren.

De rollen binnen zowel het schoolteam als de subteams worden voornamelijk vervuld door leraren, maar ook door onderwijsassistenten en pedagogisch medewerkers. Niet alle leraren met een rol in het schoolteam of de subteams zijn echter ook groepsleraren, bijvoorbeeld in het geval van de bouwleraren van school 1. Deze bouwleraren staan niet voor de klas, maar vervullen wel een belangrijke rol in het onderwijsteam. School 2 benoemt dat er expliciet niet aan functiedifferentiatie wordt gedaan. Leraren en onderwijsassistenten vervullen daar gezamenlijk de rollen in de teams, naar gelang hun interesse en kwaliteiten. Op diezelfde school hebben de ouders ook een belangrijke rol in het schoolteam, als 'educatief partners'. De taken die zij uitvoeren zijn onder andere begeleiding aan buitenactiviteiten en het bieden van ondersteuning bij het lezen in de units.

Een van de scholen heeft ervaring met de inzet van een academische leraar, maar deze bleek volgens hen op papier geschikter voor het onderwijs dan in de praktijk. Dit was voor de betreffende school een bevestiging dat zij persoonlijkheid belangrijker vinden dan diploma's bij het zoeken naar nieuwe collega's. School 3 heeft wel de wens voor het inzetten van een academische leraar, met name voor de uitvoering van data-analyserende taken, die volgens hen weinig aandacht krijgen op de pabo. Op geen van de scholen die aan dit deelonderzoek meededen is op dit moment echter een academische leraar werkzaam.

\section{Uitgangspunt rolverdeling}

Alle vijf de scholen geven aan dat talenten, interesses en ambities van teamleden het uitgangspunt zijn bij de verdeling van rollen en specialisaties. Het is dus altijd zaak een balans te vinden tussen wat nodig is op school en wat een individu kan en wil. Bij de meeste scholen (1, 2 en 5) zijn deze rollen dan ook niet vastomlijnd maar dynamisch, en worden zij vormgegeven al naar gelang de intrinsieke motivatie en expertise van de teamleden. Twee van die scholen benoemen dat er, naast het min of meer natuurlijk ontstaan van specialisaties, ook school- of teambrede (jaar)doelen zijn met bijbehorende taken, die verdeeld worden op teamniveau. Bij de andere twee scholen (3 en 4) zijn de taken binnen het team van tevoren gedefinieerd en worden daar in gesprek de juiste personen bij gezocht die ruimte krijgen voor verdere specialisatie, maar ook hier is de ontwikkelwens van het teamlid leidend.

\subsubsection{Wat is de rol van de onderwijsassistenten binnen de (sub)teams?}

\section{Visie op inzet}

Op de vijf scholen zijn één tot drie onderwijsassistenten onderdeel van het schoolteam. Twee scholen beschrijven een fundamenteel van elkaar verschillende visie op de inzet van de onderwijsassistenten bij hen op school. School $1 \mathrm{geeft}$ 
aan dat zij onderwijsassistenten alleen inzetten in groepen 1, 2 en soms 3. Deze zijn niet bevoegd en inzetbaar voor het overnemen van de klas. Op school 2 lopen de taken van leraren en onderwijsassistenten door elkaar en worden beide groepen gezamenlijk gezien als educatief professionals. Bij de andere drie scholen worden onderwijsassistenten ingezet om de druk van de teams te verlichten en de formatie rond te kunnen krijgen. Zodoende is het geen structurele oplossing voor formatieproblemen, maar wel een tijdelijke, volgens de geïnterviewden.

\section{Opleiding}

De achtergronden van de onderwijsassistenten verschillen per school. Op school 1 wordt mbo 3 in 'een relevante richting' gevraagd, op school 2 en 5 is mbo 4 in iedere richting een voorwaarde, en op school 4 werkt een onderwijsassistent die de reguliere mbo 4 opleiding tot onderwijsassistent heeft afgerond. School 3 specificeert de achtergrond van de bij hen werkzame onderwijsassistent niet.

\section{Taken}

De taken die de onderwijsassistenten vervullen, hebben veelal te maken met het begeleiden van individuele of kleine groepjes leerlingen, het ondersteunen van de groepsleraar met bijvoorbeeld het inrichten van themahoeken en lezen met leerlingen. School 3 zet onderwijsassistenten ook in voor pleinwachttaken en na schooltijd op de buitenschoolse opvang. School 2 verdeelt de taken tussen leraren en onderwijsassistenten op meer organische wijze. Er wordt bij hen geen onderscheid gemaakt tussen deze functionarissen als het gaat om taakverdeling, diegene bij wie de taak op dat moment past pakt het op. Hier en op school 1 nemen de onderwijsassistenten zodoende soms de klas over als hier behoefte aan is, ook al valt dat officieel niet binnen hun takenpakket.

\subsubsection{Op welke manier vinden de processen van werving en selectie voor de (sub)teams plaats?}

Alle scholen geven aan dat de factoren die spelen bij werving en selectie van nieuwe collega's voor alle rollen en functies hetzelfde zijn. Daar wordt dus geen onderscheid in gemaakt. Twee scholen (school 1 en 5) geven nadrukkelijk aan dat de mate waarin de persoon past bij de schoolvisie en de manier van werken het allerbelangrijkste is bij het vinden van nieuwe collega's. Kunnen en willen samenwerken en plezier willen maken met elkaar komt bij beide scholen direct na de persoonlijkheid op de prioriteitenlijst. Bij school 3 is motivatie om (te leren) les te geven en hierin verder te willen ontwikkelen de belangrijkste factor. Daar zijn zij-instromers een gewenste groep nieuwe collega's vanwege hun hoge motivatie en hun diverse expertise.

Teamleden van school 4 vertellen dat de schoolleider goed kan aanvoelen wat er nodig is in het team en dus de verantwoordelijkheid voor werving en selectie draagt. In de andere scholen heeft de schoolleider de leiding over het sollicitatieproces, maar worden teamleden hier wel in meegenomen. Dit zijn meestal de teamleden die met de kandidaat-collega zullen gaan samenwerken. Op school 3 is heeft een teamlid een vastomlijnde rol om nieuwe collega's te begeleiden en ondersteunen. Voor het uitvoeren van deze rol krijgt dit teamlid dan ook expliciet tijd.

\subsubsection{Welke ontwikkelmogelijkheden hebben de leden van de (sub)teams?}

\section{Niveau van professionalisering}

Professionalisering vindt zowel op schoolteamniveau plaats, als op subteamniveau en op individueel niveau. Leerbehoeften worden op schoolteamniveau geïnventariseerd door de schoolleider en op subteamniveau door de procesbegeleiders of teamvoorzitters. Op individueel niveau is initiatief van de medewerker nodig om ontwikkelingsmogelijkheden te benutten en ruimte te nemen om je individueel in je rol te verdiepen. Hiervoor is meestal toestemming van de directie nodig.

\section{Aanleiding en vorm van professionalisering}

Op school 2, 4 en 5 vormen de schoolbrede jaarplannen met de door het team gespecificeerde doelen de aanleiding voor scholingen. Het schoolbrede jaarplan komt met het gehele schoolteam tot stand, waarna subteams dit toespitsen op de eigen praktijk en daar de ontwikkelingsmogelijkheden zelf op organiseren. De schoolleider kan soms teamscholing ook verplicht stellen als hij/zij dit nodig acht. School- en subteamscholing vindt dan meestal plaats op studiedagen. Op school 4 wordt ook gewerkt met een vacaturemuur: jaarlijks worden de speerpunten van het jaarplan beschreven met bijbehorende taken, en individuele teamleden kunnen dan op de vacaturemuur - die op een centrale plaats in de school hangt - aangeven waar zij aan bij willen dragen en welke bijbehorende taken ze gaan uitvoeren. Drie van de vijf scholen (school 1, 2 en 3) merken op dat het deelnemen aan een subteam (expertteam of 
leerteam/unit) op zichzelf een vorm van professionele ontwikkeling is, door het werken met elkaar aan gezamenlijke kennis- en onderwijsontwikkeling en de regelmatige gezamenlijke reflectie op het handelen van het team.

School 3 geeft aan dat pabo-afgestudeerden die op deze school komen werken altijd eerst bijgeschoold worden, aangezien zij daar niet opgeleid worden tot ontwikkelaar of onderzoeker, maar enkel als lesgever, volgens de schoolleider. De bijscholing gaat dan bijvoorbeeld over de werking van het kortetermijngeheugen en wat dit betekent voor de les die je geeft aan kinderen, over de vraag hoe het werkt met parate kennis, en over de noodzaak tot herhaling van informatie.

\section{Ontwikkelmogelijkheden onderwijsassistent}

Op een van de scholen (school 1) vertelt de onderwijsassistent welke ontwikkelingsmogelijkheden zij gedurende haar loopbaan op deze school heeft ervaren. De strekking van haar ervaringen is dat zij als onderwijsassistent wel incidenteel mocht deelnemen aan scholing om bepaalde aspecten van haar taken te kunnen verbeteren, maar dat er geen aandacht was voor haar loopbaanontwikkeling en mogelijke doorgroei naar andere functies. Op dit moment gaat zij bijna met pensioen en ontwikkeling is volgens haar dus niet meer aan de orde. Zij geeft aan dat zij ongeveer 15 jaar geleden wel eens heeft nagevraagd bij de schoolleider of zij in aanmerking zou komen voor een opleiding tot lerarenondersteuner. De schoolleider die destijds het team leidde gaf echter aan dat de school op dat moment geen behoefte had aan lerarenondersteuners. Ook heeft ze pabo geprobeerd, maar omdat dit in de avonduren moest gebeuren en er privé veel speelde, heeft ze deze niet af kunnen maken, mede doordat er destijds van een onderwijsassistent die de pabo deed gevraagd werd om op een andere school stage te lopen. Dat betekende: vier dagen werken, daarnaast nog twee dagen stagelopen. Dat was niet te doen, vertelt zij. Naast deze ervaringen met opleiding en doorstroom geeft de onderwijsassistent aan in haar loopbaan wel veel mogelijkheden te hebben gekregen tot het volgen van cursussen en dat heeft haar veel gebracht. Ze heeft het als heel plezierig ervaren om via die weg nieuwe kennis op te doen en gelijk toe te kunnen passen. Maar, geeft zij aan, uiteindelijk ben je 'gewoon' onderwijsassistent. Je kunt ontwikkelen wat je wilt, maar je bent en blijt onderwijsassistent en financieel zit daar geen vooruitgang in, zegt zij. De onderwijsassistent geeft nadrukkelijk aan dat haar werk haar passie is en dat ze deze financiële prikkel niet nodig heeft om gemotiveerd te zijn voor haar werk, maar het wringt wel.

\section{Loopbaanpaden}

Alle scholen geven aan dat er geen specifieke loopbanen voor de medewerkers zijn geëxpliciteerd. Dit is het geval omdat het systeem juist werkt op basis van individuele wensen en talenten, lichten sommigen toe. Persoonlijke groeipaden worden wel uitgestippeld, aan de hand van bijvoorbeeld persoonlijke ontwikkelingsplannen, maar dit is de verantwoordelijkheid van de individuele medewerkers. Zij krijgen hierin begeleiding van de schoolleider. Teamleden van school 1 geven aan dat de schoolleider een belangrijke rol speelt in creëren van ruimte voor ontwikkeling en het leren richting geven aan de eigen behoeften en wensen. Daarvoor is het volgens hen wel belangrijk dat iedereen op de hoogte is van de mogelijkheden voor ontwikkeling en wat verschillende functies en rollen inhouden.

\subsubsection{Hoe worden individuele bijdragen aan het teamresultaat en behaalde teamresultaten geëvalueerd en gewaardeerd?}

\section{Informele en formele gesprekscyclus}

De manier waarop ontwikkel-, functionerings- en beoordelingsgesprekken worden gevoerd, verschilt per school.

In drie van de vijf scholen (school 2, 3 en 4) wordt een formele gesprekscyclus aangehouden, maar de wijze waarop deze cyclus is ingericht, verschilt. Zo bestaat de cyclus op school 2 uit jaarlijkse individuele startgesprekken, voortgangsgesprekken en functioneringsgesprekken, en tweejaarlijkse beoordelingsgesprekken. School 3 organiseert per jaar voor elk teamlid meerdere beoordelingsgesprekken volgens het CPO-model (Competentie, Passie, Organisatiedoelstellingen): een 1-op-1 gesprek met de leerteamvoorzitter, een 1-op-1 gesprek met iemand naar keuze en er is een gesprek met het hele leerteam bij elkaar. De derde school (school 4) organiseert met name ambitiegesprekken met collega's, waarnaast er ook de ruimte is om samen met de schoolleider in gesprek te gaan over persoonlijke ontwikkelingswensen. Zo wordt in de gesprekscyclus enerzijds gereflecteerd op de werkwijze van individuen en krijgt elke professional de ruimte zijn/haar ambities uit te spreken, bij te stellen en vorm te geven, en anderzijds is dit het moment om als team de talenten en ambities bij elkaar te brengen. 
De schoolleiders van school 1 en 5 geven aan de formele gesprekscyclus los te hebben gelaten, omdat het niet de gewenste motivatie en ambitie wist te stimuleren. Ook vond men dat hierdoor de nadruk te veel kwam te liggen op wat er niet goed gaat. Deze scholen hebben zodoende gekozen voor een ander soort gesprek.

In één geval (school 1) is er sprake van informele gesprekken, veelal in de wandelgangen, 1-op-1 tussen professional en schoolleider, maar ook regelmatig in teamverband. De onderwijsassistent van deze school geeft ook aan dat er met het team iedere dag na school wordt besproken hoe de dag is gegaan en wat er eventueel anders kan of moet. Een andere school (school 5) focust met name op talenten. Zij voeren individuele talentgerichte gesprekken aan de hand van de talentenscan van Luk Dewulf, gericht op kwaliteiten en drijfveren. Op teamniveau speelt deze school jaarlijks ook een talentenspel, om meer inzicht in elkaars drijfveren, talenten en doelen te krijgen.

\section{Waarderen}

School 4 geeft aan dat waarderen van elkaar een belangrijk onderdeel van de visie is. De waardering voor elkaar wordt vanuit de heersende schoolcultuur regelmatig gevoeld, vertellen teamleden. Een andere school (school 1) vertelt dat het vieren van successen een belangrijk onderdeel is van de werkwijze. Teamleden bevestigen dat er echt naar ze geluisterd wordt door de schoolleider. Uit de interviews blijkt niet dat er ook waardering in de vorm van financiële prikkels plaatsvindt.

\subsubsection{Welke mogelijkheden worden gecreëerd voor teams om samen te werken en te werken aan verbeterambities?}

\section{Ruimte}

Alle scholen geven aan dat ruimte in het rooster van de leraren nodig is en georganiseerd wordt voor teamoverleg, professionele ontwikkeling (formeel en informeel), onderwijsontwikkeling en samen werken aan bijvoorbeeld groepsplannen. Deze ruimte voor werk 'achter de schermen', bijvoorbeeld in de vorm van een ambulante dag of preparation time (waarbij een heel leerteam of een gedeelte van het team per week één dag is uitgeroosterd). Deze ruimte wordt cruciaal geacht voor de onderwijsontwikkeling en -kwaliteit. Bijkomend voordeel is dat door deze spelingsruimte altijd collega's in staat zijn tot opvangen van uitval. Echter, de specialistische kennis van deze collega's en de ruimte die wordt ingenomen door de uitgevallen lessen zijn dan niet in te zetten op de manier waarop dat bedoeld is, namelijk ter onderwijs- en kennisontwikkeling, en zodoende zorgt dit niet voor een structurele oplossing van formatieproblemen.

Voor fysieke ruimte om aan onderwijs- en expertiseontwikkeling te werken, wordt door drie scholen (school 1, 2 en 3) ook expliciet gezorgd. Zo zijn er speciale ruimtes te vinden in de school voor de leraren waar zij zich kunnen terugtrekken om individueel werk te verrichten (bijvoorbeeld het voorbereiden van oudergesprekken), of om als team te overleggen. Gecreëerde leerpleinen hebben het team op een school (school 1) dan ook letterlijk ruimte gegeven; ruimte in de klas om alle kinderen te kunnen bedienen. Op een andere school is in de teamkamer ruimte gemaakt voor borden met doelen en acties. Eens per week staan de leraren bij hun eigen bord om dit kort met de collega's te bespreken.

\section{Autonomie}

De autonomie die aan de subteams gegeven wordt, is een belangrijke factor in de onderwijskwaliteit die zij leveren, volgens de geïnterviewden. Zo geeft het geïnterviewde expertteam van school 1 aan dat het beslissingsbevoegd is, maar de houding van hun schoolleider heeft ertoe geleid dat het team deze beslissingsruimte ook daadwerkelijk kon nemen. Het organiseren van een expertteam maakt lijntjes korter, waardoor ideeën eerder tot daadwerkelijke plannen worden omgezet, en vaak ook nog schoolbreed kunnen worden uitgezet.

Ook voor het verdelen van rollen en taken wordt op twee scholen (school 3 en 4) naar tevredenheid expliciet een beroep gedaan op de eigen verantwoordelijkheid en het zelf in het vizier houden van persoonlijke ambities. Op een van deze twee scholen (school 4) is aan de onderwijsregisseur de taak deze verdeling en de samenwerking binnen het leerteam in goede banen te leiden. 


\subsubsection{In welke mate draagt de manier van teamwerken bij aan: omgaan met het lerarentekort, het reduceren van werkdruk en verzuim, het verhogen van werkgeluk en het gelijk houden of verhogen van de onderwijskwaliteit?}

\section{Balans werkdruk en werkgeluk}

Twee van de vijf scholen (school 1 en 5) geven aan geen moeite te hebben met het vinden van nieuwe medewerkers. Dit heeft volgens hen te maken met de visie op hun werkwijzen: deze spreekt externe onderwijsprofessionals aan.

Geen van de geïnterviewden ervaren een te hoge werkdruk. School 1 geeft aan: we hebben met de huidige werkwijze niet minder werk dan voorheen, maar ervaren wel minder werkdruk. Ook de verzuimcijfers zijn bij de meeste scholen laag. Dit heeft volgens drie van de vijf scholen (school 1, 2 en 5) te maken met een hoge mate van werkgeluk. Dit plezier wordt gestimuleerd door verschillende factoren volgens de geïnterviewden van de vijf scholen. De meest genoemde is het voelen van autonomie en vertrouwen, zowel voor individuen als voor de zelfstandig opererende subteams. Ook het krijgen van ruimte - zowel in het rooster als in figuurlijke zin - om te werken aan niet-lesgebonden taken zoals kennisontwikkeling en professionalisering wordt meermaals genoemd als belangrijke factor voor werkgeluk. Verder is een dialogische werkomgeving belangrijk, waarbij men kan uitspreken wat er op het hart ligt. Ten slotte wordt het voordeel van korte lijntjes die resulteren in snelle oplossingen voor acute problemen door meerdere geïnterviewden genoemd.

\section{Onderwijskwaliteit}

De vooruitgang van de onderwijskwaliteit is ten slotte volgens twee scholen (school 1 en 3 ) het directe gevolg van het

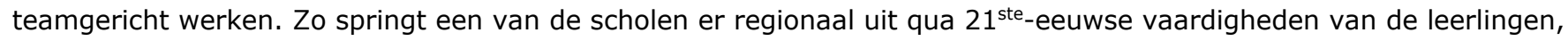
door het thematisch leren op de leerpleinen. De andere school geeft aan dat door het wegbezuinigen van de managementlagen er minder hiërarchie en meer financiële ruimte voor verbetering van de onderwijskwaliteit over blijft.

\subsubsection{Op welke manier hebben de maatregelen rondom de COVID-19 pandemie effect gehad op de manier waarop er wordt samengewerkt binnen het team?}

\section{Positieve effecten}

Ten tijde van het schoolbezoek aan de eerste school had het virus Nederland nog niet bereikt. School 2 en 3 vertellen dat door de bestaande leerteamstructuren het thuisonderwijs snel opgepakt en voortgezet kon worden, met korte onderlinge lijntjes. Men is vaardiger geworden in online meeten, wat sommige besprekingen efficiënter maakt. Dit wordt ook bevestigd door de geïnterviewden van school 5 . Een andere meermaals genoemde positieve ontwikkeling is dat ouders hun kinderen zo ook in een onderwijscontext zien en de onderwijsprofessionals een kijkje krijgen bij de kinderen achter de voordeur. Dit schept aan beide kanten inzicht en verhoogt de betrokkenheid bij elkaar.

\section{Negatieve effecten}

Helaas missen de kinderen de sociale contacten heel erg in tijden van gesloten scholen. Ook wordt op school 2 armoede bij sommige kinderen thuis geconstateerd. Gelukkig zijn er fondsen beschikbaar om devices voor hen te regelen. Het team van school 5 merkt op dat er onderling sneller sprake was van miscommunicatie en dit vervolgens minder snel werd opgelost dan dat dit face-to-face gebeurt. Zij hoopten dus heel snel weer face-to-face met elkaar aan het werk te kunnen.

\subsection{Puntsgewijze samenvatting van de belangrijkste bevindingen}

Deze rapportage behandelde een meervoudige casestudie, waarin vijf scholen hebben geparticipeerd en die als doel had om een beeld te krijgen van de wijze waarop scholen teamgericht werken met een focus op taakdifferentiatie in de praktijk vormgeven. De belangrijkste bevindingen uit dit deelonderzoek staan hieronder puntsgewijs samengevat. De bevindingen van deze deelstudie en de portretten van de vijf bezochte scholen worden meegenomen in de inhoud van de toolkit (zie hoofdstuk 6). 
Rol en taakverdeling binnen teams:

) Er zijn vier soorten teams: 1) integrale schoolteams, 2) multidisciplinaire teams met lesgevende taken (units, onderwijs- of leerteams, op basis van leerjaren), 3) monodisciplinaire teams (expertteams, focus- of werkgroepen, op basis van thema), 4) overkoepelende regiegroepen;

> Rollen binnen subteams bestaan grofweg uit: groepsleraren, specialisten, ondersteuners. Deze worden aangevuld door schoolteambrede rollen als schoolleider en administratief medewerker;

> Rollen voor functionarissen zonder lesgevende taken zijn bijvoorbeeld: kennisontwikkeling, onderwijskwaliteit en procesbegeleiding. Zij kunnen eventueel wel als invalkracht optreden;

> Rol- en taakverdelingen komen tot stand vanuit een balans tussen wat wordt gevraagd en persoonlijke ambities van teamleden.

Werving en selectie:

) Er wordt binnen de scholen geen onderscheid gemaakt in de manier van werven en selecteren per rol of functie;

> Persoonlijkheid en visie op onderwijs wordt veel belangrijker geacht dan opleidingsachtergrond;

> Werving en selectie van nieuwe teamleden wordt in alle gevallen geleid door de schoolleider, in samenspraak met relevante teamleden.

Ontwikkelingsmogelijkheden:

> Professionalisering gebeurt op schoolteam, subteam en individueel niveau;

> Ontwikkelingsmogelijkheden ontstaan veelal op basis van eigen initiatief, vanuit het team of het individu;

$>\quad$ Loopbaanpaden worden op de scholen niet geëxpliciteerd.

Onderwijsassistenten:

> Visie op inzet van onderwijsassistenten verschilt en daarmee het takenpakket en de gevraagde opleidingsachtergronden ook;

> Onderwijsassistenten kunnen tijdelijk voor lucht in de formatie zorgen, maar zijn geen structurele oplossingen voor formatieproblemen;

> Er is geen eenduidig perspectief op wat de rol en meerwaarde van de onderwijsassistent is en kan zijn;

> Voor onderwijsassistenten lijken er weinig ontwikkelmogelijkheden te zijn.

Gesprekscyclus:

> De formele en informele gesprekscyclus kent een diverse aanpak, afhankelijk van de visie van de schoolleider;

> Overeenkomst: in alle gesprekscycli ligt de nadruk op talenten, ambities en kwaliteiten.

Waarderen:

> Successen vieren is belangrijk op alle deelnemende scholen;

> Waarderen gebeurt in de vorm van aandacht en erkenning.

Ruimte:

$>$ Ruimte in het rooster (ambulante tijd, 'preparation time') voor niet-lesgebonden taken is belangrijk;

$>\quad$ Deze ruimte is niet bedoeld als oplossing voor formatieproblemen. Zonder structurele oplossingen voor formatieproblemen levert onderwijskwaliteit in.

Autonomie:

) Autonomie van (sub)teams is essentieel voor werkgeluk en kwaliteit. 


\section{Vragenlijststudie}

\subsection{Inleiding}

Dit hoofdstuk beschrijft de bevinden van een vragenlijststudie, waarin wordt voortgeborduurd op inzichten die de eerdere deelstudies hebben opgeleverd.

Uit de eerste twee deelstudies - de literatuur- en interviewstudie - kwam het beeld naar voren dat het alsmaar oplopende lerarentekort een belangrijke bron is voor de toename van werkdruk in het onderwijs. Leraren ervaren steeds vaker een disbalans tussen taakeisen en hulpbronnen: terwijl de hoeveelheid en complexiteit van het werk is toegenomen (denk aan grotere klasse, meer administratieve taken, meer diverse leerling populatie) is de regelruimte (in termen van autonomie, inspraak en steun vanuit collega's of leidinggevenden) vaak afgenomen. Deze disbalans kan leiden tot stress en burn-out symptomen. De inzet van ondersteuners zoals onderwijsassistenten en andere vormen van taakdifferentiatie kan deze disbalans verminderen, mits aan een aantal voorwaarden voldaan wordt, zoals een duidelijke (onderwijskundige) visie op ieders inzet, goede afstemming van taken en voldoende professionaliseringsmogelijkheden. Taakverdeling op basis van kwaliteiten en interesses, een zogeheten 'sterke punten benadering' dus (Van Woerkom, 2018), kan het werkgeluk verhogen en de werkdruk verlichten als hier een duidelijke onderwijskundige visie aan ten grondslag ligt en wanneer het is ingebed in het schoolbrede personeelsbeleid.

De aanbevelingen voor de praktijk die de deelstudies naar voren brachten, bleken goed ondergebracht te kunnen worden binnen het concept van teamgericht HRM. Hiermee wordt gedoeld op HRM praktijken die gericht zijn op het bevorderen van het functioneren van teams middels het vergroten van de capaciteiten, motivatie en mogelijkheden van teamleden om samen te kunnen werken aan de ontwikkeling en uitvoering van onderwijs (zie bijvoorbeeld Bouwmans, Runhaar, Wesselink, \& Mulder, 2017). Teamgericht HRM werd vervolgens als kapstok gebruikt voor de derde deelstudie, de meervoudige casestudie. In die studie is nagegaan hoe scholen taakdifferentiatie op verschillende manieren vormgeven op basis van sterke punten, en hoe dit te vertalen is in concrete teamgerichte HRM praktijken.

De vragenlijststudie die in het voorliggende rapport wordt besproken, borduurt voort op de eerste drie deelstudies door na te gaan hoe de ervaren werkdruk, het werkgeluk en vertrekintentie binnen primair onderwijsteams gerelateerd is aan de inzet van op sterke punten gebaseerde en teamgerichte HRM praktijken.

\subsection{Onderzoeksvragen binnen de vierde deelstudie: de vragenlijststudie}

Binnen deze vierde deelstudie wordt antwoord gegeven op de volgende onderzoeksvragen:

1. In welke mate en op welke manier wordt werkgeluk, werkdruk en vertrekintentie in het primair onderwijs ervaren?

2. In welke mate en hoe verschilt de ervaren werkdruk, werkgeluk, vertrekintentie en waargenomen teamgerichte HRM praktijken tussen functiegroepen (leraren, onderwijsassistenten en schoolleiders)?

3. In welke mate en hoe hangen ervaren werkgeluk, werkdruk en vertrekintentie samen met individuele verschillen tussen teamleden en met de aanwezigheid van op sterke punten gebaseerde en teamgerichte HRM praktijken?

4. Welke verbetermogelijkheden ziet men als het gaat om verlaging van de werkdruk door inzet van onderwijsassistenten en andere vormen van taakdifferentiatie?

\section{Opbouw van dit hoofdstuk}

In paragraaf 3 wordt de onderzoeksmethode beschreven en in paragraaf 4 worden de belangrijkste bevindingen gepresenteerd. Tot slot wordt in paragraaf 5 de bevindingen bediscussieerd en worden implicaties voor vervolgonderzoek en voor de praktijk geformuleerd. 


\subsection{Methode}

Met de vragenlijst zijn zowel kwantitatieve gegevens (zoals scores op schalen die werkdruk, werkgeluk en inzet van teamgerichte HRM praktijken meten) als kwalitatieve gegevens verzameld. Met dit laatste wordt gedoeld op open vragen waarmee respondenten hun scores konden toelichten.

\subsubsection{Participanten}

De vragenlijst is ingevuld door 242 participanten waaronder 18 mannen, 124 vrouwen, 2 personen die zich anders identificeerden en 99 personen van wie deze gegevens niet bekend waren. De gemiddelde leeftijd van de respondenten uit onze sample is 42.49 en varieerde tussen de 21 en 64 jaar. Deze spreiding $(S D=12.32)$ kan verklaard worden door het feit dat zowel leraren, onderwijsassistenten als schoolleiders zijn meegenomen: de gemiddelde leeftijd van schoolleiders is vaak wat hoger dan die van leraren ${ }^{15}$. Van de participanten werkte $14.5 \%$ als schoolleider, $17 \%$ als leraar en $19 \%$ als onderwijsassistent. Daarnaast bestond de steekproef uit lerarenondersteuners (6\%), leraren in opleiding ( $2 \%$ ) of mensen met een andere functie met lesgevende taken (4\%) of zonder lesgevende taken (4.5\%). Van de overige $33 \%$ was de functie niet bekend.

Van alle participanten was $8 \%$ werkzaam in het speciaal onderwijs. Daarnaast was $16 \%$ werkzaam in het religieus onderwijs, $7 \%$ in het bijzonder onderwijs op pedagogische basis en 36\% werkzaam in het openbaar onderwijs en van $41 \%$ was dit niet bekend.

Veruit de meest benaderde scholen waren gevestigd in een kleine stad of dorp (45.5\%). Verder waren $37 \%$ van de scholen gevestigd in een grote stad en $17.5 \%$ in een klein dorp of op het platteland.

\subsubsection{Procedure}

Een vragenlijst is gecreëerd in het online programma Qualtrics. De vragenlijst is deels verstuurd naar scholen die willekeurig geselecteerd zijn aan de hand van een vrijgegeven lijst met alle basisscholen in Nederland van DUO Onderzoek en Advies ${ }^{16}$. Daarnaast zijn ook scholen waar wij als onderzoeksteam al eerder contact mee hebben gehad benaderd om de vragenlijst in te vullen. Ook heeft een aantal participanten de vragenlijst gevonden via de platforms waarop deze geplaatst was, namelijk op LinkedIn, de website van het Arbeidsmarkt Platform PO, en op de website van de PO-Raad. Alle vragenlijsten zijn ingevuld tussen september 2020 en eind december 2020.

De vragenlijst bevatte 68 items, bestaande uit open en gesloten vragen. Sommige vragen waren functie-specifiek. Hierdoor heeft niet iedere vraag eenzelfde aantal respondenten. In bijlage 4 staan de vragenlijsten, zoals ze werden ingevuld door de drie groepen respondenten: leraren, onderwijsassistenten en schoolleiders. Het invullen van de vragenlijst duurde ongeveer 10 tot 15 minuten en was geheel op vrijwillige basis. Onder geïnteresseerden werd een workshop verloot waarin hulp geboden werd in teamgericht HRM.

\subsubsection{Instrumenten}

De vragenlijst bevatte grotendeels gesloten, meerkeuzevragen en daarnaast drie open vragen. Allereerst worden de gesloten vragen besproken:

Werkgeluk is in dit onderzoek geoperationaliseerd in termen van 'work engagement', wat gedefinieerd wordt als 'een positieve werk-gerelateerde mentaliteit dat gekarakteriseerd wordt door absorptie, toewijding en vitaliteit'. Werkgeluk is gemeten aan de hand van een verkorte vragenlijst bestaande uit drie subschalen (i.e. vitaliteit; toewijding; absorptie) gepresenteerd in de UBES (Schaufeli \& Bakker, 2003). Een voorbeelditem van vitaliteit is: 'Op mijn werk bruis ik van energie' (Cronbach's a = .90); toewijding: 'Ik ben enthousiast over mijn werk' (Cronbach's a = .92); absorptie: 'Ik ga helemaal op in mijn werk' (Cronbach's a = .87). De score van de participant kan per subschaal variëren tussen 1 (helemaal oneens) en 7 (helemaal eens). Deze score is berekend aan de hand van het gemiddelde van de vragen die binnen de schaal valt. De drie constructen samen zijn een betrouwbare meting voor ervaren werkgeluk (Cronbach's a $=.93$ ).

\footnotetext{
${ }^{15}$ https://www.onderwijsincijfers.nl/kengetallen/po/personeel-po/aantallen-leeftijd-personeel-po

${ }^{16}$ https://duo.nl/open_onderwijsdata/databestanden/po/adressen/
} 
Werkdruk is in dit onderzoek gedefinieerd als een staat van 'emotionele uitputting, depersonalisatie en een verminderd gevoel van persoonlijke prestaties' en gemeten aan de hand van acht vragen gepresenteerd in de UBOS (Schaufeli \& Bakker, 2003). Een voorbeelditem hiervan is: 'Ik voel me mentaal uitgeput door mijn werk' (Cronbach's a = .90). De score van de participant kan variëren tussen de 1 en de 7 , waarbij een lage score een lage ervaren werkdruk representeert.

Met op sterke punten gebaseerde en teamgerichte HRM praktijken wordt in dit onderzoek gedoeld op HRM praktijken die gericht zijn op het vergoten van de capaciteiten, motivatie en mogelijkheden van teamleden om samen te kunnen werken aan de ontwikkeling en uitvoering van het onderwijs (Bouwmans et al., 2017) en waarbij waar mogelijk de sterke punten van elk teamlid als uitgangspunt wordt genomen (Van Woerkom, 2018). Om de verschillende deelconstructen van teamgericht HRM te meten is een combinatie van items gebruikt uit het werk van Bouwmans en collega's (2017) en Van Woerkom, Meyers en Bakker (2020).

Taakdifferentiatie op basis van sterke punten, wat betekent dat de taaktoedeling gebaseerd is op ieders kwaliteiten en interesses, is gemeten door zes items uit de 'collective strength use' schaal (Van Woerkom, Meyers, \& Bakker, 2020; Meyers, Van Woerkom, Bauwens, onder review) die bestaat uit drie aspecten, namelijk: (1) het collectief bewustzijn van individuele sterke punten die aanwezig zijn in het team, (2) het vertrouwen in de sterke punten bij het uitvoeren van taken en (3) het coördineren van taken en het toewijzen van teamrollen op basis van capaciteiten. Een voorbeelditem van dit derde aspect is: 'In mijn team verdelen we taken gebaseerd op de sterke punten van teamleden' (Cronbach's a = .95). Door het gemiddelde te nemen van de zes vragen kan een score behaald worden tussen de 1 en de 7, waarbij een lage score een lage mate van taakdifferentiatie op basis van sterke punten reflecteert.

De volgende teamgerichte HRM praktijken zijn gemeten op basis van de vragenlijst van Bouwmans en collega's (2017).

Waardering van individuele bijdragen aan het teamresultaat is gemeten aan de hand van vier vragen zoals: 'Binnen mijn team wordt bij de waardering van mijn werk rekening gehouden met mijn bijdrage aan teamprestaties' (Cronbach's $a=.93$ ). Door het gemiddelde te nemen van de vier vragen kan een score behaald worden tussen de 1 en de 5, waarbij een lage score een lage mate van ervaren waardering binnen het team representeert.

Teamwaardering, wat betekent dat teams gewaardeerd worden voor het behaalde team resultaat is gemeten aan de hand van vier vragen. Een voorbeelditem van teamwaardering is: 'Bij de waardering van mijn team als geheel wordt rekening gehouden met de prestaties van mijn team' (Cronbach's a $=.94)$. Door het gemiddelde te nemen van de vier vragen kan een score behaald worden tussen de 1 en de 5, waarbij een lage score een lage mate van ervaren waardering representeert.

Team ontwikkelingsmogelijkheden, wat refereert aan professionaliseringsaanbod dat gericht is op wat teams nodig hebben om beter samen te kunnen werken en om goede team resultaten te behalen, is gemeten aan de hand van acht vragen. Een voorbeelditem hiervan is: 'Ontwikkelingsmogelijkheden zijn gericht op het verhogen van teamresultaten' (Cronbach's a = .92). Door het gemiddelde te nemen van de acht vragen kan een score behaald worden tussen de 1 en de 5, waarbij een lage score een lage mate van team ontwikkelingsmogelijkheden reflecteert.

Teamgerichte Werving en Selectie, wat inhoudt dat er in de samenstelling van teams gekeken wordt naar hoe teamleden elkaar aanvullen qua capaciteiten, is gemeten met vier vragen zoals: 'Bij de werving en selectie wordt rekening gehouden met de mate warin zij zich willen inzetten voor het teambelang' (Cronbach's a $=.96$ ). De gemiddelde score van deze vier vragen kan variëren tussen de 1 en de 5, waarbij een lage score betekent dat er weinig sprake is van teamgerichte werving en selectie.

Vertrekintentie is gemeten aan de hand van drie vragen (gebaseerd op Skaalvik \& Skaalvik, 2011). Een voorbeelditem van vertrekintentie is: 'Ik denk er vaak over om het basisonderwijs te verlaten'. Door de gemiddelde score van deze vragen samen te nemen, kan een score behaald worden tussen de 1 en de 7 , waarbij een lage score een lage behoefte om binnen de huidige functie te vertrekken representeert (Cronbach's a $=.86$ ).

Persoonskenmerken die bevraagd zijn: leeftijd (in jaren), sekse (man, vrouw, anders), ervaring in het onderwijs (in jaren) en ervaring binnen de huidige school (in jaren). 
Om meer inzicht te krijgen in de verbetermogelijkheden die men zelf ziet als het gaat om verlaging van de werkdruk door inzet van onderwijsassistenten en andere vormen van taakdifferentiatie (onderzoeksvraag 4), zijn op verschillende plekken in de vragenlijst open vragen gesteld: In Blok 2, betreffend de inventarisatie van verschijningsvormen van taakdifferentiatie en inzet van onderwijsassistenten (zie Bijlage 4), werd respondenten gevraagd aan te geven of men tevreden was over de rolverdeling binnen het team en over de samenwerking met onderwijsassistenten. Indien men deze vragen met 'nee' beantwoordde werd gevraagd om een toelichting. Aan het einde van de vragenlijst (Blok 4: vragen over de werkbeleving) is de volgende vraag gesteld: 'Indien u als team werkdruk ervaart, wat heeft uw team dan nodig om werkdruk te verminderen?'.

\subsubsection{Data analyse}

Om de eerste onderzoeksvraag ('In welke mate en op welke manier wordt werkdruk, werkgeluk en vertrekintentie in het primair onderwijs ervaren?') te beantwoorden, zijn in SPSS de gemiddelde scores en standaarddeviaties per construct berekend. Ook zijn correlatieanalyses uitgevoerd (Pearson's correlatietoets), waarbij is uitgegaan van de volgende interpretatie van de sterkte van de relatie: $r<0.5$ is zwak, $0.5<r<0.7$ is gemiddeld en $r>0.7$ is sterk (Moore et al., 2013). Daarnaast zijn de antwoorden op de open vragen waarin om toelichting op de scores werd gevraagd, thematisch gecodeerd aan de hand van een categoriseringsschema (Riessmann, 2008, zie Bijlage 5).

Om na te gaan in hoeverre werkdruk, werkgeluk en vertrekintentie verschillen per functie (onderzoeksvraag 2) zijn ANOVA-toetsen uitgevoerd met werkdruk, werkgeluk en vertrekintentie als afhankelijke variabelen.

Om inzicht te krijgen in hoe werkdruk, werkgeluk en vertrekintentie samen hangen met individuele verschillen tussen teamleden en met de aanwezigheid van op sterke punten gebaseerde teamgerichte HRM praktijken (onderzoeksvraag 3) zijn drie multipele regressie analyses uitgevoerd, met werkdruk, werkgeluk of vertrekintentie als afhankelijke variabele. De individuele en werkomgevingsfactoren zijn in beide analyses stapsgewijs als onafhankelijke variabelen meegenomen. Op deze manier wordt inzicht verkregen in de richting van de onderlinge relaties tussen variabelen.

\subsection{Bevindingen}

\subsubsection{In welke mate en op welke manier wordt werkdruk, werkgeluk en vertrekintentie ervaren?}

In Tabel 5.1 is een overzicht weergegeven van gemiddelden $(M)$ en de standaarddeviatie $(S D)$ op alle de gemeten constructen. Ook is het aantal respondenten waarbij het betreffende construct gemeten is $(n)$ weergegeven.

\section{Tabel 5.1 Gemiddelden en standaarddeviaties}

\begin{tabular}{lllll} 
& & M & SD & n \\
1 & Leeftijd & 42.49 & 12.32 & 143 \\
\hline 2 & Geslacht & 1.89 & 0.36 & 144 \\
\hline 3 & Ervaring in het onderwijs & 4.19 & 2.11 & 144 \\
\hline 4 & Werkzaam binnen school & 2.87 & 1.72 & 143 \\
\hline 5 & Werkdruk & 3.36 & 1.33 & 76 \\
\hline 6 & Werkgeluk & 5.56 & 1.15 & 76 \\
\hline 7 & Vertrekintentie & 2.55 & 1.36 & 76 \\
\hline 8 & Team ontwikkelingsmogelijkheden & 3.50 & 0.94 & 97 \\
\hline 9 & Taakdifferentiatie & 4.33 & 1.39 & 112 \\
\hline 10 & Waardering als team & 3.46 & 1.01 & 97 \\
\hline 11 & Waardering binnen het team & 3.36 & 1.10 & 97 \\
\hline 12 & Werving en selectie & 3.43 & 1.18 & 106 \\
\hline
\end{tabular}

De gemiddelde score op werkgeluk (5.56) ligt boven het schaalgemiddelde (4) en is daarmee relatief hoog. De spreiding van de antwoorden $(S D=1.15)$ is relatief laag. De gemiddelde score van werkdruk $(M=3.36)$ ligt onder het 
schaalgemiddelde (4) te liggen en is daarmee relatief laag. De spreiding van de antwoorden $(S D=1.33)$ is ook hier relatief laag. De gemiddelde score op vertrekintentie is in onze sample heel laag ( 2.55 op een schaal van 1 tot 7 ) en ook hier is sprake van een lage spreiding $(S D=1.36)$.

Het antwoord op de eerste onderzoeksvraag is samenvattend: de respondenten uit onze sample ervaren relatief weinig werkdruk, relatief veel werkgeluk en rapporteren een lage vertrekintentie. De lage spreidingen geven aan dat de scores van de respondenten uit onze sample behoorlijk dicht bij elkaar liggen.

\subsubsection{In welke mate en hoe verschilt de ervaren werkdruk, werkgeluk, vertrekintentie en waargenomen teamgerichte HRM praktijken tussen functiegroepen (leraren, onderwijsassistenten en schoolleiders)?}

In Tabel 5.2 is een overzicht gegeven van de ANOVA analyses.

\section{Tabel 5.2 Overzicht ANOVA's per functie}

\begin{tabular}{lllll} 
& & $\boldsymbol{d}$ & $\boldsymbol{F}$ & $\boldsymbol{P}$ \\
1 & Werkdruk & 1,62 & 0.20 & .655 \\
\hline 2 & Werkgeluk & 1,62 & 0.41 & .523 \\
\hline 3 & Vertrekintentie & 1,62 & 1.19 & .279 \\
\hline 4 & Ontwikkelingsmogelijkheden & 2,82 & 12.57 & $<.001$ \\
\hline 5 & Taakdifferentiatie & 2,95 & 8.01 & .001 \\
\hline 6 & Waardering als team & 2,82 & 16.14 & $<.001$ \\
\hline 7 & Waardering binnen het team & 2,82 & 9.82 & $<.001$ \\
\hline 8 & Werving en selectie & 2,91 & 4.68 & .012 \\
\hline
\end{tabular}

De ANOVA analyses laten geen significante verschillen zien in de afhankelijke variabelen (i.e. werkdruk, werkgeluk en vertrekintentie) tussen functies. Dit betekent dat zowel het werkgeluk als de werkdruk en vertrekintentie niet significant verschillend worden ervaren door leraren, onderwijsassistenten en schoolleiders.

Wel blijkt dat er wel significante verschillen zijn tussen als het gaat om alle teamgerichte HRM praktijken (ontwikkelingsmogelijkheden, taakdifferentiatie, waardering als team en binnen het team, en de werving \& selectie). Uit post-hoc analyses blijkt dat deze verschillen met name zitten tussen schoolleiders enerzijds, en leraren en onderwijsassistenten anderzijds: schoolleiders scoren significant hoger op alle teamgerichte HRM praktijken dan leraren en onderwijsassistenten, wat betekent dat zij die meer terugzien in hun teams dan leraren en onderwijsassistenten dat doen.

\subsubsection{In welke mate en hoe hangen ervaren werkgeluk, werkdruk en vertrekintentie samen met individuele verschillen tussen teamleden en met de aanwezigheid van op sterke punten gebaseerde teamgerichte HRM praktijken?}

Uit de correlatie analyse (Tabel 5.3) blijkt dat werkgeluk positief gerelateerd is aan alle vier de gemeten teamgerichte HRM praktijken (team ontwikkelingsmogelijkheden; taakdifferentiatie; waardering voor het teamwerk als geheel; waardering binnen het team). Dit betekent bijvoorbeeld dat iemand die meer mogelijkheden voor teamontwikkeling ervaart op zijn of haar school, ook een verhoging van de werkgeluk ervaart, en andersom. Werkgeluk blijkt ook negatief gerelateerd te zijn aan werkdruk en vertrekintentie, wat betekent dat iemand die meer werkgeluk ervaart, minder werkdruk ervaart en minder de behoefte heeft om bij deze school te vertrekken, en andersom. Werkdruk is positief gerelateerd aan vertrekintentie, wat betekent dat wanneer respondenten een hogere werkdruk ervaren, zij ook een hogere vertrekintentie rapporteren. Werkdruk is negatief gerelateerd aan twee van de vier gemeten teamgerichte HRM praktijken, namelijk taakdifferentiatie en waardering binnen het team. Dat wil zeggen dat naarmate respondenten minder taakdifferentiatie op basis van sterke punten en waardering voor individuele bijdragen aan het team ervaren, dit gepaard gaat met een hogere ervaren werkdruk.

Alle vier de teamgerichte HRM praktijken zijn positief aan elkaar gerelateerd. Naarmate men dus meer van het één ervaart, ervaart men ook meer van het ander. Van de individuele kenmerken is alleen de Ervaring in het onderwijs gelinkt aan twee van de afhankelijke variabelen: hoe langer men al werkzaam is in het onderwijs, hoe meer werkdruk 
wordt gerapporteerd $(r=.30, \mathrm{p}<.01)$ en hoe hoger de vertrekintentie is $(r=.23, \mathrm{p}<.05)$. De gemeten individuele kenmerken vertonen verder geen samenhang met afhankelijke of onafhankelijke variabelen. In de regressieanalyses is dan ook alleen de ervaring in het onderwijs als variabele meegenomen.

Tabel 5.3 Correlaties (tweezijdig) Tussen Constructen

\begin{tabular}{|c|c|c|c|c|c|c|c|c|c|c|c|}
\hline & 1 & 2 & 3 & 4 & 5 & 6 & 7 & 8 & 9 & 10 & 11 \\
\hline \multicolumn{12}{|l|}{1 Leeftijd } \\
\hline 2 Geslacht & -.08 & & & & & & & & & & \\
\hline $\begin{array}{l}3 \text { Ervaring in het } \\
\text { onderwijs }\end{array}$ & $.72 * *$ & -.05 & & & & & & & & & \\
\hline $\begin{array}{l}4 \text { Werkzaam binnen } \\
\text { school }\end{array}$ & $.49 * *$ & .03 & $.61^{* *}$ & & & & & & & & \\
\hline 5 Werkdruk & .22 & .10 & $.30 * *$ & .21 & & & & & & & \\
\hline 6 Werkgeluk & -.03 & -.11 & -.06 & .02 & $-.33 * *$ & & & & & & \\
\hline 7 Vertrekintentie & .14 & .01 & $.23 *$ & .14 & $.60 * *$ & $\begin{array}{l}- \\
.47 * *\end{array}$ & & & & & \\
\hline $\begin{array}{l}8 \text { Team ontwikkelings- } \\
\text { mogelijkheden }\end{array}$ & .10 & -.16 & .07 & .06 & -.17 & $.47^{* *}$ & -.17 & & & & \\
\hline 9 Taakdifferentiatie & .03 & -.04 & .02 & .10 & $-.36 * *$ & $.33 * *$ & $-.31 * *$ & $.60 * *$ & & & \\
\hline $\begin{array}{l}10 \text { Waardering als } \\
\text { Team }\end{array}$ & .08 & -.08 & .02 & -.03 & -.21 & $42 * *$ & -.15 & $.78^{* *}$ & $.55^{* *}$ & & \\
\hline $\begin{array}{l}11 \text { Waardering binnen } \\
\text { het team }\end{array}$ & .01 & -0.4 & .01 & .01 & $.23 *$ & $.50 * *$ & $-.27 *$ & $.60 * *$ & $.58 * *$ & $.77^{* *}$ & \\
\hline 12 Werving en selectie & -.05 & -.03 & -.07 & .11 & $-.31 * *$ & $.46 * *$ & $-.27 *$ & $.67 * *$ & $.59 * *$ & $.69 * *$ & $.58 * *$ \\
\hline
\end{tabular}

$*=\mathrm{p}<.05 ; * *=\mathrm{p}<.01$; cursieve waarden representeren Kendall's tau-b; overige waarden representeren Pearsons correlatie coëfficiënt.

Tabel 5.4 laat de uitkomsten van drie regressieanalyses zien met elk één van de drie afhankelijke variabelen (werkdruk, werkgeluk en vertrekintentie). Via de Enter methode is telkens eerst ervaring in het onderwijs als onafhankelijke variabele ingevoerd en zijn in een tweede stap de teamgerichte HRM praktijken aan de analyse toegevoegd.

Tabel 5.4 Regressieanalyses met Werkdruk en Werkgeluk als afhankelijke variabelen

\begin{tabular}{|c|c|c|c|c|c|c|}
\hline \multirow{2}{*}{$\begin{array}{l}\text { Werkdruk } \\
\text { Model }\end{array}$} & \multicolumn{2}{|c|}{ Werkdruk } & \multicolumn{2}{|c|}{ Werkgeluk } & \multicolumn{2}{|c|}{ Vertrekintentie } \\
\hline & 1 & 2 & 1 & 2 & 1 & 2 \\
\hline Ervaring in onderwijs & $.30 * *$ & $.26 *$ & -.06 & .00 & $.23 *$ & .18 \\
\hline Taakdifferentiatie & & $-.30 *$ & & -.03 & & -.18 \\
\hline Waardering binnen het team & & .01 & & $.42 * *$ & & -.25 \\
\hline Waardering als team & & -.10 & & -.26 & & .26 \\
\hline Team ontwikkelingsmogelijkheden & & .18 & & $.32 t$ & & -.03 \\
\hline Werving \& selectie & & -.19 & & .22 & & -.17 \\
\hline $\mathrm{R}^{2}$ & .09 & .23 & .00 & .34 & .05 & .18 \\
\hline R change & & $.14^{*}$ & & $.34 * *$ & & .131 \\
\hline
\end{tabular}

Tabel 5.4 laat zien dat het aantal jaar ervaring in het onderwijs positief gerelateerd is aan werkdruk (zie Werkdruk Model $1: \beta=.30, p<.01)$. Dit positieve effect blijft bestaan als de teamgerichte HRM praktijken in de analyse meegenomen worden, al neemt het wat af (Werkdruk Model 2: $\beta=.26, \mathrm{p}<.05$ ). Dit betekent dat hoe meer ervaring de 
respondent heeft in het onderwijs, hoe meer werkdruk ervaren wordt. Van de teamgerichte HRM praktijken heeft alleen Taakdifferentiatie op basis van de sterke punten van teamleden een negatief effect op de ervaren werkdruk. Hoe meer taakdifferentiatie gerapporteerd wordt, hoe minder de ervaren werkdruk.

Als we kijken naar werkgeluk, dan laat Tabel 5.4 zien dat Ervaring in het onderwijs hieraan niet gerelateerd is. Tevens blijkt dat de Waardering van de individuele bijdrage aan het teamresultaat een positieve impact te hebben op werkgeluk (Werkgeluk Model 2: $\beta=.42, \mathrm{p}<.01$ ). Datzelfde geldt voor Team ontwikkelingsmogelijkheden, zij het dat dit effect marginaal significant was (Werkgeluk Model 2: $\beta=.32, p<.10$ ). Hoe meer men ervaart dat de individuele bijdrage van teamleden aan het teamresultaat wordt erkend en hoe meer team ontwikkelmogelijkheden men ervaart, hoe meer werkgeluk er gerapporteerd wordt.

Tabel 5.4 laat tot slot zien dat Vertrekintentie samenhangt met Ervaring in het onderwijs (Vertrekintentie Model 1: $\beta=.23, \mathrm{p}<.05)$ maar dat dit effect verdwijnt als de teamgerichte HRM praktijken in de analyse worden meegenomen (Vertrekintentie Model 2: $\beta=.18$, n.s.). Geen van de teamgerichte HRM praktijken blijkt overigens significant samen te hangen met Vertrekintentie.

\section{Additionele regressieanalyse}

Gegeven de uitkomsten van de correlatie analyse (Tabel 5.3) is in een additionele analyse gekeken hoe de verschillende afhankelijke variabelen gelinkt zijn aan elkaar. Het is immers voor te stellen dat naarmate de werkdruk hoger is en het werkgeluk lager, de vertrekintentie toeneemt. Dit blijkt inderdaad het geval te zijn (zie Tabel. 5.5).

$\begin{array}{lcc}\begin{array}{l}\text { Tabel } \\ \text { 5.5 Regressieanalyse met Vertrekintentie als afhankelijke variabele en Werkdruk en Werkgeluk als } \\ \text { onafhankelijke variabelen }\end{array} & 2 \\ \begin{array}{lcc}\text { Model } & 1 & .06 \\ \text { Ervaring in Onderwijs } & .23^{*} & -.31^{* *} \\ \hline \text { Werkgeluk } & & .48^{* *} \\ \hline \text { Werkdruk } & & .45 \\ \hline \mathrm{R}^{2} & .05 & .40^{* *} \\ \hline \mathrm{R} \text { change } & & \\ \hline\end{array}\end{array}$

Analoog aan Tabel 5.1 laat ook Tabel 5.3 een positieve samenhang zien tussen Ervaring in het onderwijs en Vertrekintentie $(\beta=.23, \mathrm{p}<.05)$. Deze samenhang verdwijnt echter als werkdruk en werkgeluk in de analyse worden meegenomen $(\beta=.06$, n.s. ). Hoe minder werkdruk en hoe meer werkgeluk respondenten ervaren $(\beta=-.31, p<.01$ resp. $\beta=.38, p<.01)$, hoe lager hun vertrekintentie is.

\subsubsection{Welke verbetermogelijkheden ziet men als het gaat om verlaging van de werkdruk door inzet van onderwijsassistenten en andere vormen van taakdifferentiatie?}

\section{Werkdrukverlaging algemeen}

Ongeveer een derde van de respondenten $(n=28)$ geeft aan dat de oplossing voor de ervaren werkdruk gezocht kan worden in de werkwijze van het bestaande schoolteam, en niet per definitie in het aantrekken van nieuw personeel. Zo zou er volgens ongeveer de helft van deze groep behoefte zijn aan meer tijd voor andere verplichtingen binnen de school dan het lesgeven zelf, zoals het voorbereiden van lessen. Een ander groot deel van deze groep geeft aan dat administratieve lastenverlichting een enorme bijdrage zou leveren aan de werkdrukvermindering. Zo geeft iemand het volgende aan: 'Ik hou van mijn werk in de klas. De randzaken, extra taken, administratie, baal ik van. Het lijkt erop dat er steeds meer op mijn bordje ligt. Mijn teamgenoten ervaren dit ook zo'.

Ongeveer een derde van de respondenten $(n=26)$ geeft aan dat de werkdruk verlicht kan worden door de inzet van meer personeel, bijvoorbeeld als het gaat om extra tijd of hulp bij het begeleiden van leerlingen met speciale behoefte. Zo geeft iemand aan behoefte te hebben aan 'extra handen en extra tijd. Meer expertise gewenst'. Anderen geven specifieker aan behoefte te hebben aan meer onderwijsassistenten ter verlichting van de werkdruk. Er wordt aangegeven behoefte te hebben aan 'meer ondersteuners zodat het draagvlak groter is en er bij ziekte altijd een oplossing is'. Daarnaast geeft een enkeling aan dat het zou helpen als vakleerkrachten lessen kunnen overnemen. 
Ook worden suggesties aangedragen door participanten voor de manier waarop het personeel wordt ingezet. Zo zou betere communicatie en goede afspraken tussen teamleden kunnen helpen, evenals het hebben van een eenduidig plan waar niet te veel en/of te vaak van wordt afgeweken: 'Duidelijke afspraken, een kader waarin gewerkt wordt en niet te veel veranderingen worden doorgevoerd'. Naast het belang van duidelijke afspraken wordt vaak in één adem genoemd dat de schoolleider hierin een cruciale rol speelt: 'Een directeur met overzicht en oog voor alle medewerkers'. Tot slot geeft een aantal leraren $(n=19)$ aan meer gebruik te willen maken van elkaars kwaliteiten, 'Meer inzet op kwaliteiten en interesses van individuele leerkrachten'. Ook geeft eenzelfde aantal aan behoefte te hebben aan meer autonomie en meer vrijheid te willen om eigen keuzes te maken.

\section{Inzet van onderwijsassistenten}

61 Respondenten geven aan dat binnen hun team samengewerkt wordt met onderwijsassistenten. Van deze participanten is $65 \%$ tevreden over de samenwerking met onderwijsassistenten en $35 \%$ niet. Op verschillende manieren wordt ruimte voor verbetering gezien: onderwijsassistenten geven aan zich soms ondergewaardeerd te voelen, zowel in de salariëring als in de taken die zij toegeschreven krijgen. Zo geeft een van de onderwijsassistenten aan: 'Ik krijg voornamelijk karweitjes. Mijn kwaliteiten worden niet volledig benut'. Ook wordt door meerdere respondenten aangegeven dat er weinig duidelijkheid en inspraak is over welke taken ze exact moeten doen en vaker niet betaald worden naar de taken die zij uitvoeren. Bijvoorbeeld: 'Ik werk fulltime en heb de opleiding lerarenondersteuner voltooid. Helaas krijg ik niet betaald als lerarenondersteuner, maar voel ik wel die werkzaamheden uit'. Daarnaast is er behoefte aan betere communicatie. Er wordt vaak onvoldoende met onderwijsassistenten gecommuniceerd en afgesproken. Een onderwijsassistent geeft bijvoorbeeld aan: 'Er wordt vaak voor mij beslist. Ik zou graag meer inspraak willen hebben over mijn taken'. Ook geeft een aantal respondenten aan dat de samenwerking effectiever kan, maar ook dat de kwaliteit van onderwijsassistenten erg verschillend kan zijn. Het niveau van onderwijsassistenten voldoet niet altijd aan de verwachtingen. Verder geeft een groot deel van de respondenten aan geen geld te hebben voor onderwijsassistenten.

Er wordt vaak aangegeven dat onderwijsassistenten onmisbaar zijn en zorgen voor de nodige werkdrukverlichting. Zo wordt er bijvoorbeeld aangegeven dat het fijn is om onderwijsassistenten binnen de school te hebben, omdat ze veel werk uit handen nemen en ondersteunen op veel verschillende gebieden. Daarnaast geeft een aantal participanten aan de onderwijsassistent te zien als een volwaardig lid van het team. Een lerarenondersteuner zegt hier bijvoorbeeld over: 'Ik ben net zozeer deel van het team als iedereen'. Ook geeft een groep aan dat de samenwerking en communicatie erg goed verloopt met de onderwijsassistenten. Zo geeft een onderwijsassistent aan: 'Heldere, open en fijne manier van samenwerken'.

Ondanks dat er ruimte is voor verbetering, is het merendeel van de participanten (64\%) tevreden over de inzet van onderwijsassistenten. De verbetering die nodig is, zit met name in het verbeteren van de communicatie en het verhelderen van taken.

\section{Taakdifferentiatie}

De verdeling van taken is volgens $27 \%$ vastgelegd in het personeelsbeleid. Verder geeft $2 \%$ aan dat dit niet is vastgelegd, $11 \%$ dat dit soms wel, soms niet is vastgelegd en $15 \%$ dat zij dit niet weten. Daarnaast is dit gegeven van $46 \%$ van de participanten niet bekend. Van de participanten bij wie dit wel bekend is, is $72.5 \%$ tevreden over de manier waarop dit is vastgelegd en $27.5 \%$ is ontevreden.

De antwoorden op de open vragen bevestigen het beeld dat de meerderheid van de respondenten tevreden is over de wijze waarop taken binnen het team verdeeld worden. Zo wordt bijvoorbeeld aangegeven dat taken evenwichtig verdeeld zijn op basis van competenties, kwaliteiten en interesses van de teamleden. Wat echter verbeterd kan worden is het feit dat de taakverdeling vaker niet vanuit het personeel tot stand is gekomen. De taakverdeling wordt vaker gemaakt door mensen die dit 'al jaren' doen. Hierdoor voelen leraren zich niet altijd gehoord. Ook omdat er vaak grote verschillen zijn in taakomvang en dit niet altijd eerlijk verdeeld of beloond wordt. Rollen worden bij velen verdeeld op basis van het aantal uren wat iemand te kort komt, in plaats van op basis van interesses of kwaliteiten. 


\subsection{Conclusie}

Deze vragenlijststudie, waaraan voornamelijk schoolleiders, leraren en onderwijsassistenten hebben meegewerkt, laat zien dat er relatief weinig werkdruk en relatief veel werkgeluk wordt ervaren. Gerelateerd hieraan bleek de vertrekintentie van onze respondenten gering.

De scores bleken niet te verschillen per functiegroep (schoolleiders, leraren en onderwijsassistenten). Wel bleken schoolleiders hoger te scoren op de teamgerichte HRM praktijken dan de leraren en onderwijsassistenten.

Van de gemeten individuele kenmerken (leeftijd, geslacht, ervaring in het onderwijs en op de school) bleek alleen het aantal jaren ervaring gerelateerd te zijn aan de ervaren werkdruk en het werkgeluk: hoe meer ervaring, hoe meer werkdruk en hoe minder werkgeluk. De vertrekintentie bleek (nadat overige variabelen in de analyse werden meegenomen) niet te samen te hangen met individuele kenmerken.

Verder suggereren de resultaten dat teamgerichte HRM praktijken een positieve impact kunnen hebben op werkdruk en werkgeluk, zij het dat het verschilt per praktijk. Terwijl taakdifferentiatie op basis van ieders sterke punten, als enige van de gemeten teamgerichte HRM praktijken, samen gaat met een verlaging van de ervaren werkdruk, blijkt werkgeluk alleen positief samen te hangen met de waardering van ieders individuele bijdrage aan het team resultaat en (in geringere mate weliswaar) de ervaren mogelijkheden die het team geboden wordt om zich verder te ontwikkelen. De vertrekintentie blijkt geen rechtstreeks verband te houden met de ervaren teamgerichte HRM praktijken, maar hangt wel samen met de werkdruk en het werkgeluk. Hoe hoger de werkdruk en hoe lager het werkgeluk, hoe hoger de vertrekintentie.

Deze resultaten geven, in combinatie met de antwoorden van respondenten op de open vragen, aan dat inzet van meer teamgerichte HRM praktijken potentie heeft. Hoewel extra 'handen in de klas' kunnen helpen om de werkdruk te verlagen, is het ook zinvol om te kijken naar de taakverdeling: onderwijsassistenten kunnen de werkdruk verlagen als zij taken op zich nemen die deze werkdruk veroorzaken. Dit dient in goed overleg te gebeuren. Over taakverdeling in het algemeen wordt onder meer opgemerkt dat het effectiever is naarmate teamleden hier zelf over mee kunnen beslissen en er oog is voor ieders kwaliteiten. 


\section{De resultaten samengebracht in een toolkit}

\subsection{Terugblik op de deelstudies}

Het onderzoek richtte zich op twee belangrijke onderdelen in relatie tot werkdruk en werkgeluk, namelijk (taak)differentiatie en de inzet van ondersteuners zoals onderwijsassistenten. Deze twee onderwerpen zijn bestudeerd aan de hand van een literatuurstudie (hoofdstuk 2), een interviewstudie met experts uit de praktijk (hoofdstuk 3), een verdiepende meervoudige casestudie van vijf scholen (hoofdstuk 4) en een vragenlijststudie onder leraren, onderwijsassistenten en schoolleiders (hoofdstuk 5). We zetten hier kort de belangrijkste bevindingen ten aanzien van elk van beide onderwerpen op een rij.

In het algemeen valt op (zie hoofdstuk 3) dat er op het gebied van taakdifferentiatie binnen scholen al veel initiatieven in het PO-veld zijn ontstaan de afgelopen jaren. Experts in de interviewstudie beschreven verschillende binnenschoolseen buitenschoolse voorbeelden van deze initiatieven. Een voorbeeld hiervan is het initiatief om (structureel) schooloverstijgende vakspecialisten in te zetten op scholen in de vorm van themadagen of -dagdelen en opleidingsprogramma's.

Verder valt in de resultaten op dat de respondenten die op ons onderzoek hebben gereageerd relatief laag scoren op werkdruk of vertrekintentie en relatief hoog op werkgeluk. Hierbij is ervaring van belang: meer ervaren respondenten scoren hoger op werkdruk, en lager op werkgeluk dan zij met minder ervaring. Ook opvallend is dat er geen significatie verschillen bleken in deze zaken tussen schoolleiders, onderwijsassistenten en leraren. Dit beeld van een relatief lage werkdruk komt niet overeen met de vele signalen van hoge werkdruk die in de media naar voren komt en ook in eerder onderzoek is bevestigd (bijvoorbeeld Hummel et al., 2019). Nader onderzoek is nodig om te achterhalen welke oorzaken er aan de discrepantie tussen de resultaten van dit onderzoek en het beeld dat eerder onderzoek en in de media wordt geschetst, te achterhalen.

Respondenten in de interviewstudie geven een aantal redenen voor werkdruk. De drie meest genoemde redenen zijn het lerarentekort, te weinig ruimte gedurende de werkdag om achter de schermen aan niet-lesgebonden taken te kunnen werken (i.e. ambulante tijd), en gebrek aan strategisch personeelsbeleid, i.e. een duidelijke visie, duidelijke rollen en taken en voldoende tijd, autonomie en ruimte voor ontwikkeling. De scholen in de meervoudige case studie hebben juist door het ontwikkelen van een dergelijk strategisch personeelsbeleid, het (her)ontwerpen van een schoolbrede visie op de inzet van de professionals een vorm van teamwerk kunnen ontwikkelen waarin duidelijke rollen en taken bestaan die verdeeld zijn op basis van kwaliteiten en interesses. Ook deze scholen geven echter aan dat het lerarentekort verdere ontwikkeling belemmert en momenteel een gevaar vormt voor van bijvoorbeeld ambulante tijd. Juist het waarborgen van deze ambulante tijd en het geven van autonomie aan leraren om (onder andere) deze ambulante tijd in te vullen, is cruciaal voor werkgeluk van de onderwijsprofessionals en het waarborgen van de kwaliteit van het onderwijs.

\subsubsection{De inzet van onderwijsassistenten}

Uit alle deelstudies blijkt dat de inzet van onderwijsassistenten de werkdruk kan verlagen. Volgens de literatuur worden onderwijsassistenten vooral ingezet voor het ondersteunen en begeleiden van leerlingen, extra begeleiding van leerlingen met achterstanden, en voor surveillance- of pleinwachten.

De literatuur noemt ook een aantal randvoorwaarden voor de inzet van onderwijsassistenten: duidelijkheid over de rol en toegevoegde waarde van onderwijsassistenten benoemen, een duidelijke visie vanuit de schoolleiding op de inzet van onderwijsassistenten, goede voorbereiding van werkzaamheden van assistenten, assistenten mogelijkheden tot professionalisering en verdere ontwikkeling bieden, en assistenten toegang geven tot praktische faciliteiten en informatie. Uit de interviews met experts blijkt dat het daarnaast van belang is goede afspraken en communicatie te organiseren tussen de onderwijsassistenten en het overige personeel. Ook blijken er naast onderwijsassistenten nog andere 'ondersteuners' gezocht te worden, zoals flexibele krachten uit vervangerspoules en bovenschoolse vakspecialisten. Daarnaast worden academische leraren en zij-instromers genoemd. Uit de verdiepende casestudie 
blijkt dat - in tegenstelling tot wat de literatuur suggereert - onderwijsassistenten vaak weinig mogelijkheden krijgen tot verdere ontwikkeling. Wel blijkt dat er vaak een visie aanwezig is op hun inzet.

Ruim twee derde van de respondenten in de vragenlijststudie geeft aan tevreden te zijn over de inzet van onderwijsassistenten. Onderwijsassistenten geven zelf vaak aan zich ondergewaardeerd te voelen, zowel qua financiële beloning als qua toebedeelde taken. Ook geven zij een gebrek aan communicatie aan. Leraren en schoolleiders geven aan dat zij onderwijsassistenten als volwaardig lid van het team zien. Zij ervaren een verlichting van werkdruk (en verhoging van werkgeluk) door hun inzet.

\subsubsection{Differentiatie binnen teams (anders organiseren)}

Uit de literatuurstudie blijkt dat differentiatie op verschillende manieren in schoolteams vorm krijgt, zowel formeel als informeel. Formele manieren zijn taak- en functiedifferentiatie, meer informele manieren zijn roldifferentiatie of 'jobcrafting' (het zelf vorm geven van de eigen functie). De verdiepende casestudie laat zien dat er vier soorten teams zijn waarbinnen taken kunnen worden gedifferentieerd: het gehele schoolteam, multidisciplinaire teams met lesgevende taken, monodisciplinaire teams, en overkoepelende regiegroepen. Scholen maken daarbij onderscheid tussen rollen van groepsleraren, specialisten, ondersteuners, schoolleiders en administratief medewerkers. De rollen en differentiatie worden ingezet op basis van persoonlijke ambities en vanuit wat gevraagd wordt vanuit de context, namelijk de school. Vanuit de vragenlijststudie blijkt dat schoolleiders positiever zijn over de mate van differentiatie op hun school dan leraren en onderwijsassistenten.

De literatuur laat zien dat differentiatie kan leiden tot meer efficiëntie en verlaging van werkdruk. De interviewstudie met experts bevestigt dat differentiatie leidt tot verlaging van de werkdruk. Daarnaast noemen experts ook verhoging van werkgeluk, ondersteuning van teamwerk, en het verhogen van de professionele leercultuur. Uit de vragenlijststudie blijkt dat taakdifferentiatie leidt tot een verlaging van de ervaren werkdruk. Waardering voor de individuele bijdrage

aan een team en ontwikkelingsmogelijkheden bleken positief bij te dragen aan werkgeluk. Uit de vragenlijststudie blijkt dat de inzet van extra personeel de werkdruk kan verlichten, evenals het verbeteren van bestaande werkwijzen van teams, betere communicatie en afspraken tussen teamleden en een eenduidige visie of plan.

De literatuurstudie laat een aantal randvoorwaarden zien voor succesvolle differentiatie, namelijk: zicht op ieders kwaliteiten en interesses, verdelen van taken en daarbij afstemmen en vertrouwen op afspraken, duidelijke afbakening van rollen en taken, voldoende mogelijkheden tot professionalisering, voldoende tijd en middelen om taken af te kunnen ronden, en een duidelijke visie op eenieders inzet en waarde in het onderwijsproces. In de interviewstudie met experts worden deze randvoorwaarden elk afzonderlijk bevestigt. De experts geven aan dat strategisch personeelsbeleid van belang is: een lange termijnvisie, heldere en formele afstemming van taken en verantwoordelijkheden, het integreren van onderwijsassistenten in het functiebouwwerk en het aanvullen van het functiebouwwerk met vervangerspoules en vakspecialisten. Ook benadrukken zij het belang van teamgericht personeelsbeleid, waarbij teams zelf regie mogen voeren over het teambeleid, het nemen van geleidelijke en kleine stappen in plaats van radicale veranderingen en het organiseren van ruimte. Opvallend in de verdiepende casestudie is dat loopbaanpaden vaak niet zijn geëxpliciteerd en dat professionele ontwikkeling vaak vooral vanuit eigen initiatief van de docent (of assistent) tot stand komt. Verder spelen schoolleiders een grote rol bij werving en bij de formele gesprekscyclus. In de meervoudige casestudie komt ook het belang van waardering, ruimte gedurende de lesdag en autonomie van leraren(teams) naar voren.

\subsection{De bevindingen van de studie samengebracht in een toolkit: de Manometer}

Op basis van de resultaten van de vier deelstudies is een toolkit ontwikkeld voor de praktijk, de 'Manometer'. Met deze toolkit kunnen schoolteams of individuele professionals op eenvoudige wijze in kaart brengen in welke mate zij binnen het team de zaken op orde hebben als het gaat om de balans tussen werkdruk en werkgeluk. Op basis van antwoorden van teamleden ontvangt men vervolgens concrete en goed uitvoerbare adviezen met betrekking tot de taak- en rolverdelingen in het team en de inzet van, bijvoorbeeld, onderwijsassistenten en lerarenondersteuners. De ontwikkeling van de checklist, de Manometer, was mogelijk omdat de literatuurstudie en de multiple case studie, zoals in dit rapport beschreven, een duidelijke set aan criteria of randvoorwaarden liet zien die van belang is bij zowel 
taakdifferentiatie als de inzet van ondersteuners, zoals onderwijsassistenten. Voor wat betreft de onderwijsassistenten ging dit om een duidelijke rol binnen het team en curriculum, goede afstemming over taken en autonomie, en voldoende mogelijkheden tot verdere ontwikkeling. Voor wat betreft differentiatie ging dit om het inzetten van een sterke puntenbenadering (op basis van interesses en kwaliteiten), duidelijke en voortdurende afstemming tussen teamleden, en voldoende mogelijkheden voor verdere ontwikkeling. Daarnaast ging het om het hebben van een strategisch personeelsbeleid en teamgericht personeelsbeleid: visie, ruimte en autonomie voor teams, middelen, duidelijke afspraken over rollen en taken, goede communicatie.

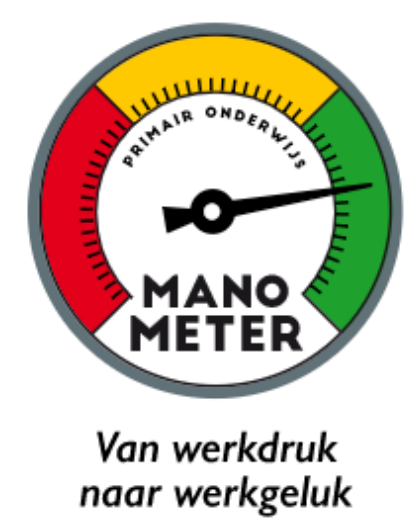

Deze criteria konden goed geordend worden naar de principes van op sterke punten gebaseerd en teamgericht HRM (zie de theoretische uitgangspunten die beschreven zijn in hoofdstuk 1). De basis voor deze benadering wordt gevormd door de 'AMO theory of Perfomance' (Appelbaum et al., 2000 ) - die stelt dat het functioneren van medewerkers een functie is van hun capaciteiten (Ability) en motivatie (Motivation) enerzijds en de mogelijkheden (Opportunity) die hen geboden worden om optimaal te functioneren anderzijds ${ }^{17}$.

De drie domeinen uit AMO theorie zijn vervolgens vertaald naar 'Zorgen voor Teamcapaciteit' (Ability domein); 'Stimuleren van Teammotivatie' (Motivation domein); en 'Faciliteren van Teamwerk' (Opportunity domein). Binnen elk van deze domeinen zijn vervolgens drie indicatoren ondergebracht die uit de verschillende deelonderzoeken naar voren gekomen zijn.

Scholen kunnen in de toolkit een account aanmaken, waarbij ze hun teamleden de meter laten invullen. Daaruit komen vervolgens een aantal scores op de verschillende indicatoren, in de vorm van een stoplicht. Wanneer een indicator groen is, is deze voldoende ontwikkeld of aanwezig, bij oranje is de indicator aanwezig maar kan zij verder versterkt worden, terwijl bij rood meer aandacht voor de indicator nodig is.

Elke indicator wordt in de toolkit verder toegelicht en omschreven. Tevens worden tips en concrete aandachtspunten bij elke indicator genoemd, die vanuit de literatuur naar voren zijn gekomen. Bij elke indicator zijn voorbeelden te vinden vanuit de praktijk, zoals ze in ons onderzoek naar voren kwamen vanuit interviews met de praktijkexperts of vanuit de casestudie. Ten slotte zijn bij elke indicator ook links naar andere relevante webpagina's opgenomen.

De afbeelding op de volgende pagina geeft een impressie van hoe de toolkit eruit ziet.

\footnotetext{
${ }^{17}$ Deze theorie staat aan de basis van het gedachtegoed rond Strategisch HRM zoals dit recent in de po sector is geïntroduceerd (https://www.samenslimmerpo.nl/document/onderzoek-strategisch-personeelsbeleid-het-primair-onderwijs-gion) maar heeft ook in de vo-sector (https://www.vo-raad.nl/themas/organisatie-ontwikkeling/onderwerpen/strategisch-hrm) en de mbo sector (https://www.nro.nl/sites/nro/files/migrate/teamleiders-aan-het-roer-van-teamontwikkeling.pdf) als inspiratie gediend.
} 


\section{POAAD}
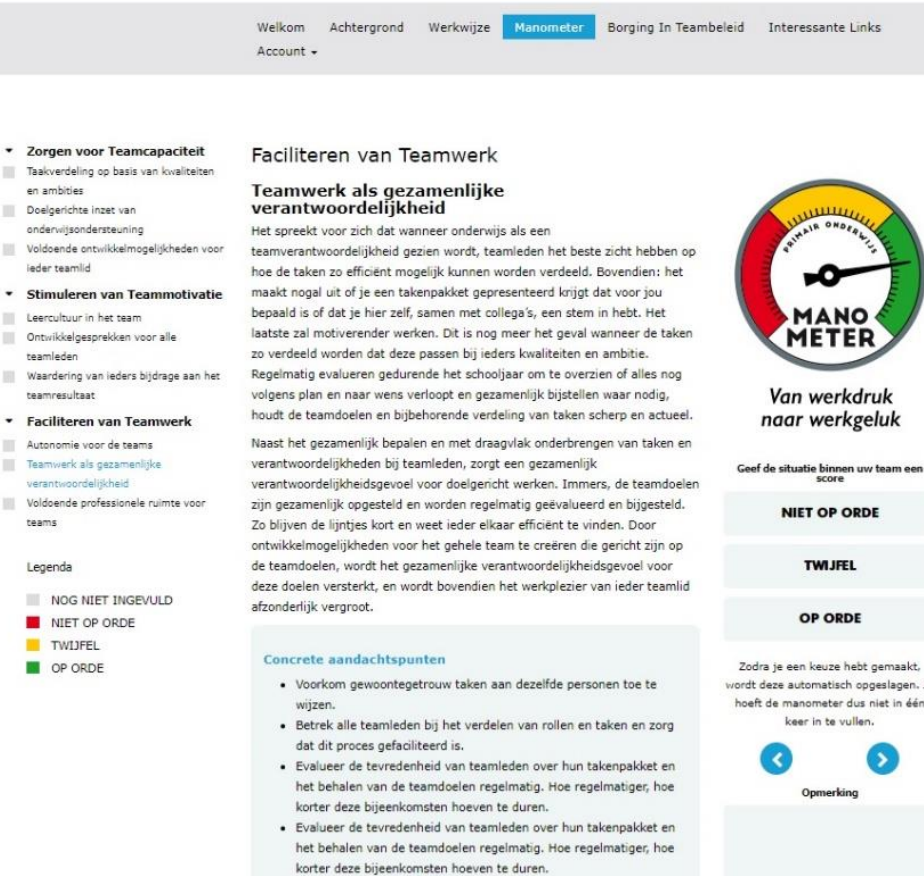

Van werkdruk

naar werkgeluk

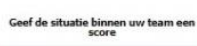

NIET OP ORDE

TwנJеt

OP ORDE

Zodra je een keuze hebt gemaskte
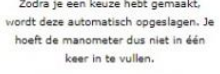

(5)

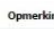

korter deze bjeenkomsten hoeven te duren.

De toolkit geeft bewust geen blauwdruk van de beste aanpak, maar wel handreikingen waarmee scholen zelf aan de slag kunnen. Wat in de praktijk wel en niet goed werkt, verschilt namelijk per school. Daarom geeft de toolkit, op basis van de scores die uit de ingevulde vragenlijsten rollen, aanbevelingen op maat. We verwachten dat de schoolleiding en medewerkers daarover met elkaar in gesprek gaan. Waar staan we nu en waar willen we naartoe? Welke stappen moeten we daarvoor nemen? In de toolkit delen we een format waarmee zij makkelijk een plan van aanpak kunnen maken voor zowel taakdifferentiatie in het team en de inzet van onderwijsassistenten als strategisch en teamgericht HRM-beleid.

De toolkit is ondergebracht bij de website van de PO-Raad. Bij de ontwikkeling is een aantal maal gekeken met een expertpanel van leraren, schoolleiders en een onderwijsassistent of de informatie helder en bruikbaar was, en of de opzet van de toolkit logisch in elkaar zat. Op basis van hun feedback (zie bijlage 6) is de toolkit verder verbeterd. 


\section{Referenties}

Adriaens, S., Van Grinsven, V., Van der Woud, L. \& Westerik, H. (2016). Rapportage werkdruk leraren in het basisonderwijs. Utrecht: DUO Onderwijsonderzoek \& Advies.

Appelbaum, E., Bailey, T., Berg, P., Kalleberg, A. L., \& Bailey, T. A. (2000). Manufacturing advantage: Why highperformance work systems pay off. Cornell University Press.

* Baar, E. (2018). Academische geschoolde basisschoolleraren zijn anders, niet beter. Geraadpleegd van: https://www.scienceguide.nl/2018/10/academische-leerkrachten-anders/.

* Bach, S., Kessler, I., \& Heron, P. (2006). Changing job boundaries and workforce reform: the case of teaching assistants. Industrial Relations Journal, 37(1), 2-21.

Backbier, E., Frielink, S. J., \& Groeneveld, M. (2001). Taakbesteding en taakbelasting van leraren in het Primair Onderwijs: kalenderjaar 2000. Ministerie van Onderwijs en Wetenschappen.

* Bates, S. M., Mellin, E., Paluta, L. M., Anderson-Butcher, D., Vogeler, M., \& Sterling, K. (2019). Examining the influence of interprofessional team collaboration on student-level outcomes through school-community partnerships. Children \& Schools, 41(2), 111-122.

* Bolhaar, J., \& van Ruijven, K. (2019). Het effect van bijzondere nadere vooropleidingseisen op de pabo. Den Haag: Centraal Planbureau.

* Boogaard, M., Blok, H., Van Eck, E., \& Schoonenboom, J. (2004). Ander onderwijs, minder leraren. Amsterdam: SCOKohnstamm Instituut.

* Bouwmans, M., Runhaar, P., Wesselink, R., \& Mulder, M. (2017). Stimulating teachers' team performance through team-oriented HR practices: the roles of affective team commitment and information processing. The International Journal of Human Resource Management, 1-23.

* Broeks, L., Bakker, W., Hertogh, E., Van Meeuwen-Kok, J., \& Grondwe, M. (2018). Loopbaanpaden in het primair onderwijs. Utrecht: Berenschot Groep B.V

Cohen, S. G., \& Bailey, D. E. (1997). What makes teams work: Group effectiveness research from the shop floor to the executive suite. Journal of management, 23(3), 239-290.

Creemers, B. \& Kyriakides, L. (2015). Process-Product Research: A Cornerstone in Educational Effectiveness Research. Journal of Classroom Interaction, 50(2), 107-119.

* De Putter, L. \& Den Brok, P. (2015). De inzet van studenten in het engineering onderwijs. Rapportage. Eindhoven: ESOE-TU/e.

* DUO Onderwijsonderzoek \& Advies. (2019). Rapportage Onderzoek Werkdrukmiddelen. Utrecht: DUO Onderwijsonderzoek \& Advies.

* Galton, M., \& MacBeath, J. (2010). Balancing the workload equation in English primary schools: a continuing story?. Asia-Pacific Journal of Teacher Education, 38(4), 301-315.

* Goetz, K. (2000). Perspectives on Team Teaching A Semester I Independent Inquiry. Egallery Exemplary Student Scholarship Master of Teaching Program Faculty of Education, 1(4).

Graham, R.H. (2018). Career Framework for University Teaching. London: Royal Academy of Engineering

* Gronn, P. (2009). Leadership configurations. Leadership, 5(3), 381-394.

Houtman, I. \& Stege, J. (2015). Rapportage werkdruk onderzoek in het vo. Delft: TNO.

* Hulsbos, F. \& Langevelde, S. (Eds., 2017). Gespreid Leiderschap in Het Onderwijs: Elkaar Invloed Gunnen Voor Vernieuwing. Utrecht: Kessels \& Smit Publishers.

* Hummel, L., Hooftman, W., \& Schelvis, R. (2019) Werkdruk in het onderwijs. Den Haag: TNO.

* Imants, J. G. M. (1996). Leiding geven aan onderwijs!: onderwijskundig leiderschap en taakdifferentiatie in basisscholen. DSWO Press, Rijksuniversiteit Leiden.

Jansen in de Wal, J., Van den Beemt, A., Martens, R., \& Den Brok, P. (2018). The relationship between job demands, job resources and teachers' professional learning: is it explained by self-determination theory? Studies in Continuing Education, DOI:10.1080/0158037X.2018.1520697.

* Kennisrotonde. (2019). Hoe kunnen de kwaliteiten van onderwijsassistenten effectief worden benut in het basisonderwijs? (KR. 513) Den Haag: Kennisrotonde.

* Kurver, B. \& D. Driessen, (2018). Onderwijsassistenten. Nijmegen: ResearchNed.

* Leana, C., Appelbaum, E., \& Shevchuk, I. (2009). Work process and quality of care in early childhood education: The role of job crafting. Academy of Management Journal, 52(6), 1169-1192. 
* MacBeath, J. (2005). Leadership as distributed: A matter of practice. School Leadership \& Management, 25(4), 349366.

* Meirink, J. A., Imants, J., Meijer, P. C., \& Verloop, N. (2010). Teacher learning and collaboration in innovative teams. Cambridge journal of education, 40(2), 161-181.

Meyers, M. C., Van Woerkom, M., \& Bauwens, R. (under review). Collective Strengths Use and Team Performance: A 21-2 Multilevel Study.

Moore, D. S., Notz, W. I., \& Fligner, M. A. (2013). The basic practice of statistics ( $8^{\text {th }}$ ed). US: WH Freeman

* Nieuwenhuis, L. (2013). Werken aan goed beroepsonderwijs. Intreerede Lectoraat Beroepsonderwijs. Nijmegen: HAN Hogeschool.

OESO (2019). Talis 2018 Results. Teachers and school leaders as lifelong learners. Volume I. Genève: OECD. https://doi.org/10.1787/1d0bc92a-en.

* Onderwijsraad (2018). Een krachtige rol voor schoolleiders. Den Haag: Onderwijsraad.

* Oonk, C., Beers, P.J., \& Wesselink, R. (2013). Doceren in Regioleren. Rollen, taken en competenties van docenten in regionale leerarrangementen. Wageningen: WUR-ECS.

* Örtqvist, D. \& Wincent, J. (2006). Prominent consequences of role stress: a meta-analytic review. International Journal of Stress Management, 13(4), 399.

Reezigt, G. J., Rekers-Mombarg, L. T. M., Bosker, R. J., \& Van der Heide, S. (2019). Personeelsbeleid in het primair onderwijs. Algemeen en strategisch personeelsbeleid van schoolbesturen en schoolleiders. Groningen: GION onderwijs/onderzoek Rijksuniversiteit Groningen.

Riessmann, C. K. (2008). Narrative methods for the human sciences. Thousand Oaks, CA: Sage Publications, Inc.

Rijksoverheid (2018). Een lerarentekort op uw school? Wat is er mogelijk en waar moet u op letten. Den Haag: Ministerie van Onderwijs, Cultuur en Wetenschappen \& Inspectie van het onderwijs.

Rudolph, C. W., Katz, I. M., Lavigne, K. N., \& Zacher, H. (2017). Job crafting: A meta-analysis of relationships with individual differences, job characteristics, and work outcomes. Journal of Vocational Behavior, 102, $112-138$.

Runhaar, P. (2017). How can schools and teachers benefit from Human Resources Management? Conceptualising HRM from content and process perspectives. Educational Management Administration \& Leadership. 45(4), 639-656.

* Runhaar, P., Gulikers, J., Wesselink, R., \& Wallenaar, M. (2019). Start Wijzer! Een brede blik op verbetering van inductie. In: Helms-Lorenz, M., Schellings, G., \& Runhaar, P. (Eds.). Begeleiding Startende leraren. Praktijk en theorie. Antwerpen-Apeldoorn: Garant Publishers.

* Ryall, A. \& Goddard, G. (2003). Support staff in primary schools: Reflections upon the benefits of training and implications for schools. Education 3-13, 31(1), 72-78.

Schaufeli, W. B. \& Bakker, A. B. (2003). Test manual for the Utrecht Work Engagement Scale. Unpublished manuscript, Utrecht University, the Netherlands. Retrieved from http://www.schaufeli.com.

Schaufeli, W. B. \& Van Dierendonck, D. (2000). UBOS Utrechtse Burnout Schaal: Handleiding. Swets Test Publishers.

Schaufeli, W. B. \& Taris, T. (2013). Het Job Demands-Resources model: overzicht en kritische beschouwing. Gedrag \& Organisatie, 26(2), 182-204.

* Sharples, J., Blatchford, P., \& Webster, R. (2018). Making best use of teaching assistants. Education Endowment Foundation.

Skaalvik, E. M. \& Skaalvik, S. (2011). Teacher job satisfaction and motivation to leave the teaching profession: Relations with school context, feeling of belonging, and emotional exhaustion, Teaching and Teacher Education, 27, 1029-1038. doi: 10.1016/j.tate.2011.04.001.

* Snoek, M. \& Volman, M. (2014). The impact of the organizational transfer climate on the use of teacher leadership competences developed in a post-initial Master's program. Teaching and Teacher education, 37, 91-100.

* Spillane, J. (2005). Distributed leadership. The Educational Forum, 69(2), 143-150.

* Struyve, C., Meredith, C., \& Gielen, S. (2014). Who am I and where do I belong? The perception and evaluation of teacher leaders concerning teacher leadership practices and micropolitics in schools. Journal of Educational Change, 15(2), 203-230.

* Van den Berg, D., Scheeren, J., \& Arslan, Z. (2017). Anders organiseren, minder tekort?. Den Haag: CAOP.

* Van den Heuvel-Panhuizen, M., \& De Goeij, E. (2005, May). Offering primary school teachers a multiapproach experience-based learning setting to become a mathematics coordinator in their school. In 15th ICMI Study Conference: The Professional Education and Development of Teachers of Mathematics. Águas de Lindóia, Brazil.(available at 10 August 2006 at http://stwww. weizmann. ac. il/G-math/ICMI/log in. html).

Van Grinsven, V., Elphick, E. \& Van der Woud, L. (2012). Rapportage werkdruk in het primair onderwijs. Utrecht: DUO Onderwijsonderzoek. 
* Van Wingerden, J., Bakker, A. B., \& Derks, D. (2017). Fostering employee well-being via a job crafting intervention. Journal of Vocational Behavior, 100, 164-174.

* Van Woerkom, M. (2018). Het gebruik van sterke punten in teams en organisaties: Transactive Strengths Systems. Arnhem: NSvP - Innovatief in Werk.

* Van Woerkom, M. \& Meyers, M. C. (2019). Strengthening personal growth initiative; The effects of a strengths intervention on personal growth initiative with general self-efficacy as moderator and Mediator. Journal of Occupational and Organizational Psychology, 92, 98-121.

Van Woerkom, M., Meyers, M. C., \& Bakker, A. (2020). Considering strengths use in organizations as a multilevel construct. Human Resource Management Review. 


\section{Bijlage 1: Teamgericht personeelsbeleid als ordeningskader voor vervolgstudies}

Met teamgericht personeelsbeleid wordt beoogd dat teams zo goed mogelijk functioneren en presteren. Om te bepalen waar personeelsbeleid dan precies over gaat, wordt veelal gebruik gemaakt van de 'AMO theory of Perfomance' (Appelbaum, Bailey, Berg, Kalleberg, \& Bailey, 2000), die stelt dat performance van medewerkers een functie is van capaciteiten (Ability) en motivatie (Motivation) van medewerkers en de mogelijkheden (Opportunity) die hen geboden worden om optimaal te functioneren. Door Bouwmans et al. (2017) en Runhaar et al. (2019) is de AMO-theorie gelinkt aan teamwork en is beschreven waar het in teamgericht personeelsbeleid om draait, namelijk:

$>\quad$ dat er in de samenstelling van teams gekeken wordt naar hoe teamleden elkaar aanvullen qua capaciteiten én dat het professionaliseringsaanbod gericht is op wat teams nodig hebben om beter samen te kunnen werken en om goede team resultaten te behalen (Ability);

$>\quad$ dat teams gewaardeerd worden voor het behaalde team resultaat en dat medewerkers gewaardeerd worden voor hun individuele bijdrage aan het team resultaat (Motivation);

> dat er mogelijkheden zijn voor teams om nieuwe kennis op te doen door contacten te leggen met mensen buiten het team en dat er voldoende mogelijkheden zijn voor teams om samen te werken en te werken aan verbeterambities (Opportunity).

Teamgericht personeelsbeleid kan als kapstok dienen om de succesfactoren van verschillende HRM praktijken (zoals de inzet van onderwijsassistenten (OA) en taakdifferentiatie) in kaart te brengen. Bijvoorbeeld in het 'ability'-domein zal het gaan om zaken als werving en selectie en professionele ontwikkeling van OAs; in het 'motivation'-domein zal onder meer ingegaan worden op beoordeling en beloning van OAs en in het 'opportunity'-domein gaat het bijvoorbeeld om de onderlinge taakverdeling in teams.

Het woord 'team' kent overigens meerdere betekenissen. Als we de definitie van, bijvoorbeeld, Cohen en Bailey (1997) volgen dan wordt een 'echt team' gedefinieerd als een groep individuen die van elkaar afhankelijk zijn bij de uitvoering van hun taken; die gezamenlijk verantwoordelijk zijn voor uitkomsten; die zichzelf zien als een eenheid binnen het grotere geheel en zo ook door anderen worden gezien.

In de praktijk wordt echter onder team vaak een hele school of locatie verstaan. Deze teams zijn daarom niet altijd 'echte' teams volgens de bovenstaande omschrijving, maar bestaan op zijn minst uit meerdere sub-teams. Denk bijvoorbeeld aan de leraren van groepen $1 \& 2$ op een basisschool die werkwijzen op elkaar moeten afstemmen en als team verantwoordelijk zijn voor een goede doorstroom naar de vervolggroepen. 


\section{Bijlage 2: Topiclijst explorerende interviews}

1. Functie en relatie / expertise primair onderwijs

2. Ervaring met werkdruk

Laag en hoog werkgeluk (waardoor beïnvloed? Hoe te meten?)

Zelf en omgeving

3. Ervaring met interventies m.b.t. werkdruk / lerarentekort / laag werkgeluk.

Effectief? Wanneer effectief (voorwaarden) en hoe te meten?

4. Ervaring met taakdifferentiatie m.b.t. werkdruk / lerarentekort / laag werkgeluk.

Effectief? Wanneer effectief (voorwaarden) en hoe te meten?

5. Ervaring met inzet onderwijsassistentie m.b.t. werkdruk / lerarentekort / laag werkgeluk. Hoe komen ze binnen? Criteria?

Welke taken voeren onderwijsassistenten uit op school?

Doorstroom onderwijsassistentie naar leraarschap?

Effectief? Wanneer effectief (voorwaarden) en hoe te meten?

6. Casus in gedachten - good practice?

7. Input voor survey: wat niet vergeten?

8. Survey verspreiding: idee voor ingang? 


\section{Bijlage 3: Topiclist interviews casestudies}

\section{Introductie}

Alle (groeps)interviews worden in het zelfde stramien gevoerd zodat de data op gestructureerde wijze samengevoegd kan worden en overeenkomsten en verschillen tussen de percepties van verschillende groepen of actoren binnen teams / scholen gemakkelijker aan het licht komen. Anders gezegd: op deze manier krijgen we een compleet beeld van hoe teamgericht HRM er op jullie school uitziet.

De clusters van topics die we gaan bespreken, zijn gebaseerd op het concept Teamgericht HRM:

Teamgericht HRM is gebaseerd op de AMO theory of Performance (Appelbaum et al., 2000) die stelt dat prestaties van individuen en teams worden bepaald door capaciteiten (Ability) en motivatie (Motivation) van medewerkers en de mogelijkheden (Opportunity) die hen geboden worden om optimaal te functioneren.

De verschillende clusters worden hieronder verder uitgewerkt en van centrale vragen voorzien.

Bij alle topics wordt niet alleen naar de stand van zaken maar ook naar gewenste situatie gevraagd.

\section{School:}

\section{Wie of welk team:}

\section{Ability}

In de samenstelling van teams (d.m.v. rol- en taakverdeling en werving en selectie) kijken naar hoe teamleden elkaar aanvullen qua capaciteiten én de ontwikkelmogelijkheden. We richten ons op wat teams nodig hebben om goed (of nog beter) samen te kunnen werken en om goede teamresultaten te behalen.

\section{Rol en taakverdeling binnen (sub) teams}

> Welke rollen en taken worden binnen uw team onderscheiden?

> Door welke functionaris(sen) worden deze rollen en taken bij voorkeur ingevuld?

> Hoe worden deze rollen en taken gedefinieerd?

> Welke factoren spelen een rol bij het verdelen van rollen en taken?

> Wat is de rol van de onderwijsassistent?

\section{Werving \& selectie}

Als er nieuwe teamleden gezocht, welke factoren spelen dan een rol?

Welke factor is het belangrijkste?

Verschilt de aanpak per rol?

In welke mate/op welke manier?

In hoeverre worden overige relevante teamleden bij het aantrekken van nieuwe teamleden betrokken?

\section{Ontwikkelmogelijkheden}

$>\quad$ In welke mate beslissen jullie op teamniveau wat de teamleden doen aan professionele ontwikkeling?

) En hoe kom je (samen) tot zo'n beslissing?

$>\quad$ In welke mate zijn loopbaanpaden binnen uw school geëxpliciteerd?

> In welke mate helpt het je (of het team) om richting te geven aan je eigen loopbaan? 


\section{Motivation}

De individuele bijdrage aan het teamresultaat evalueren en waarderen en teams belonen voor behaalde teamresultaten.

> Vinden er regelmatig ontwikkel-, functionerings- en beoordelingsgesprekken plaats met alle teamleden?

$>\quad$ In welke regelmaat?

$>\quad$ In welke mate wordt hierin zowel ingegaan op ieders individuele inzet en prestaties als op ieders bijdrage aan het teamresultaat?

$>\quad$ In welke mate worden/voelen teams gewaardeerd voor hun inzet en prestaties (door de rest van de school/door andere teams/door teamleden van het team)?

\section{Opportunity}

Mogelijkheden creëren voor teams om samen te werken en te werken aan verbeterambities In welke mate beschikt uw team over voldoende ruimte, tijd en middelen om:

1. Goed samen te werken?

2. Rollen en taken goed af te stemmen

3. Samen te werken aan onderwijsontwikkeling?

\section{Uitkomsten van teamgericht HRM}

Idealiter stimuleert teamgericht HRM het teamleren, samenwerking en teamontwikkeling. We hopen dat het ook bijdraagt aan de uitkomsten die in ons NRO onderzoek centraal staan, nl: omgaan met lerarentekort, terugdringen werkdruk, verhogen werkgeluk en gelijk houden of zelfs verhogen van onderwijskwaliteit.

In welke mate draagt jullie manier van teamwerk bij aan:

1. Omgaan met het lerarentekort

2. Het reduceren van werkdruk en verzuim

3. Het verhogen van werkgeluk

4. Het gelijk houden of verhogen van de onderwijskwaliteit

We hebben nu een aantal HR-instrumenten besproken (werving en selectie, ontwikkelings-mogelijkheden, evalueren en waarderen, praktische facilitering van teamwerk).

Als je de vier bovenstaande aspecten bekijkt, welk zgn. HR-instrument heeft jullie dan het meeste opgeleverd (welke aanpak)? 


\section{Bijlage 4: Vragenlijst leraren, onderwijsassistenten, schoolleiders}

De vragenlijst is uitgezet in drie verschillende varianten: een voor leraren, een voor onderwijsassistenten en een voor schoolleiders. IN onderstaande weergave zijn deze drie varianten geïntegreerd weergegeven.

\section{Vragenlijst}

\section{Introductie}

Het zijn rare tijden. $U$ bent ongetwijfeld bezig met creatieve manieren om het onderwijs anders te organiseren. We hopen dat de eerste onrust achter de rug is en dat het aangepaste onderwijs op uw school draait. Mocht u 10-15 minuten willen en kunnen vrijmaken om middels deze vragenlijst uw licht te schijnen over het thema 'anders organiseren in primair onderwijsteams', dan ontvangen we heel graag uw antwoorden.

Het primair onderwijs kampt al jaren met toenemende werkdruk. Onderzoekers van Wageningen University \& Research en Tilburg University voeren onderzoek uit naar de organisatie van het onderwijs om deze werkdruk te verminderen en bovenal het werkplezier te vergroten, in opdracht van het ministerie van Onderwijs, Cultuur en Wetenschap.

Centraal staat de vraag in hoeverre, op welke manier en onder welke voorwaarden de inzet van onderwijsassistenten en taakdifferentiatie binnen teams bij kan dragen aan het reduceren van werkdruk en het verhogen van werktevredenheid/werkplezier.

Middels verschillende onderzoeksmethoden, zoals een literatuurstudie, schoolbezoeken en deze vragenlijst, beogen we een toolkit te ontwikkelen die actoren binnen scholen kan helpen bij de inzet van onderwijsassistenten en andere vormen van taakdifferentiatie.

Het eerste blok van de vragenlijst vraagt om demografische gegevens omtrent uw school. Het tweede blok inventariseert de vormen van taakdifferentiatie en de inzet van onderwijsassistenten binnen uw school. Het derde blok bevraagt verschillende aspecten van teamgericht HRM. Tot slot bevat het vierde blok vragen over uw persoonlijke werkbeleving.

Uw antwoorden op de vragen zijn na het invullen te downloaden door uzelf. Zo heeft u een overzicht van de stand van zaken bij u op school gecreëerd.

Alle antwoorden op de vragen worden vertrouwelijk en anoniem behandeld. Deze zijn, naast uzelf, alleen en anoniem in te zien door de onderzoekers.

Alvast veel dank voor het invullen van de vragenlijst!

Aniek Draaisma, Nienke Woldman, Piety Runhaar, Marianne van Woerkom en Perry den Brok (Het onderzoeksteam) 


\section{Toestemmingsverklaring}

Hierbij verklaar ik dat ik vrijwillig aan dit onderzoek deelneem en hierbij geef ik toestemming om mijn antwoorden op de vragen in deze vragenlijst anoniem te verwerken en analyseren in het kader van wetenschappelijk onderzoek uitgevoerd door Wageningen University \& Research en Tilburg University.

De postcode van de school waarop ik werkzaam ben is:

We stellen u deze vraag om uw antwoorden te kunnen clusteren met de antwoorden van eventuele collega's van uw school, om de data zo zuiver mogelijk te kunnen analyseren. We zullen de postcode niet gebruiken om te achterhalen op welke school uw werkzaam bent en uw individuele resultaten te bekijken. Uw anonimiteit blijft gewaarborgd.

\section{Blok 1: Demografische gegevens}

A. Wat is uw leeftijd?

B. Wat is uw geslacht?
$\square \quad$ Man
$\square$ Vrouw
$\square$ Anders

C. Specifiek voor Onderwijsassistenten: Weke route heeft u gevolgd om onderwijsassistent te worden?

Mbo niveau 4

$\square$ Zij-instroom in het beroep

$\square$ Anders, namelijk

D. Hoe lang bent $u$ al werkzaam in het primair onderwijs?
Minder dan 1 jaar
1 tot 5 jaar
6 tot 10 jaar
11 tot 15 jaar
16 tot 20 jaar
21 tot 25 jaar
26 tot 30 jaar
Meer dan 30 jaar

E. Hoe lang bent u al werkzaam op uw huidige school?
Minder dan 1 jaar
1 tot 5 jaar
$\square 6$ tot 10 jaar
$\square 11$ tot 15 jaar
16 tot 20 jaar
21 tot 25 jaar
26 tot 30 jaar
Meer dan 30 jaar 
F. Uit hoeveel scholen bestaat de onderwijsstichting waar uw school onder valt?

$\square \quad 1$ (eenpitter)
$\square \quad 2-5$
$\square \quad 6-10$
$\square \quad 10+$

G. Werkt u op een school voor bijzonder onderwijs?
Nee
$\mathrm{Ja}$

Bijzonder op religieuze basis

Bijzonder op pedagogische basis (denk aan Dalton, Jenaplan, etc.)

H. Hoeveel leerlingen heeft uw school?
100 leerlingen
100-200 leerlingen
200-300 leerlingen
300-400 leerlingen
400-500 leerlingen
$500+$ leerlingen

I. In wat voor type gemeente is uw school gevestigd?

$\square$ In een klein dorp of op het platteland (minder dan 10.000 inwoners)

$\square \quad$ In een kleine stad of dorp (tussen 10.00 en 100.000 inwoners)

$\square \quad$ In een grote stad (meer dan 100.000 inwoners)

J. In hoeverre is het voor uw school moeilijk om aan leraren (vaste krachten) te komen?

De vragen in deze vragenlijst worden vaak gesteld vanuit een teamperspectief. Met de term 'team' doelen we binnen deze vragenlijst op het gehele schoolteam, dus het gezamenlijke team van alle personeel binnen uw school.

Bij het beantwoorden van de vragen wordt u dus gevraagd de gang van zaken binnen uw schoolteam in gedachten te houden. Daar waar 'team' geschreven staat, kan dus ook 'school' gelezen worden.

\section{Blok 2: Inventarisatie van verschijningsvormen taakdifferentiatie en inzet van onderwijsassistenten}

1.

Welke functie vervult $u$ in het team? Met functie wordt de formele functie, zoals beschreven in het functiebouwhuis, bedoeld. Indien dit er meerdere zijn, kiest u dan degene die de overhand heeft en vult u de lijst vanuit die functie in.

Administratief medewerker / ondersteuner

Conciërge

Onderwijsassistent

Lerarenondersteuner 
A) Welke rollen, ofwel specialismen, worden binnen uw team onderscheiden?
Begeleider startende leraren
Bouwcoördinator
Coach coöperatief leren
Coach hoogbegaafdheid
Coach schoolbrede veranderingen (schoolcoach)

$\square$ Event manager

$\square$ Expertrol t.a.v. vakken (Engels, rekenen, taal, geschiedenis, biologie, godsdienst etc.)

$\square$ IPC-coach (IPC = International Primary Curriculum)

$\square$ Mediacoach (coach om leraren/ leerlingen/ ouders te helpen om met (social) media om te gaan)

$\square$ Remedial teaching, ambulante zorg

$\square$ Vakleraar bewegingsonderwijs

$\square$ Anders, namelijk:

\section{B) DROPDOWN PER ROL:}

a. Welke functionaris vervult deze rol?

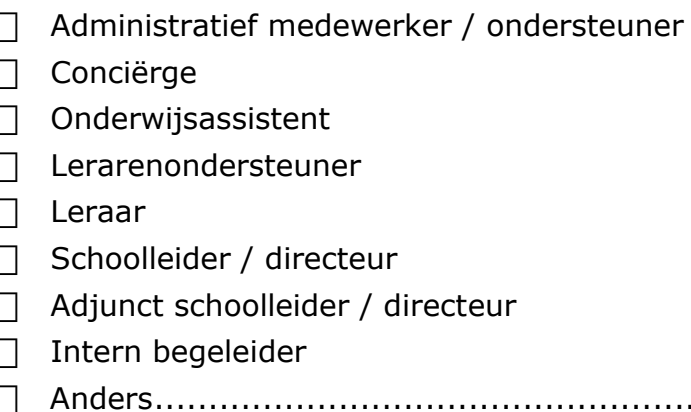

b. Is deze verdeling van rollen in het personeelsbeleid vastgelegd?
$\mathrm{Ja}$
Nee

Bent u hier tevreden over?
Ja

$\square$ Nee

Licht kort toe.

A) Wordt er binnen de school door u of uw collega's (samen)gewerkt met onderwijsassistenten?

$\mathrm{Ja}$

Nee

Bent u hier tevreden over? 
Licht kort toe.

B) (Verschijnt alleen indien 'ja' is ingevuld bij 3a) In welke mate voeren de onderwijsassistenten binnen uw school de volgende taken uit? Kruis aan wat van toepassing is, waarbij een ' 1 ' staat voor 'helemaal niet, en een ' 5 ' staat voor 'heel veel.

Administratieve ondersteuning

Ondersteunen en begeleiden van leerlingen

Overnemen van lessen

Extra begeleiding voor leerlingen met een achterstand

Surveillance- en pleinwachttaken

Anders, namelijk:
12345

12345

12345

12345

12345

12345

C) DROPDOWN PER ROL: In welke mate zou u wensen dat onderwijsassistenten deze taken uitvoeren? Kruis aan wat van toepassing is, waarbij een ' 1 ' staat voor 'helemaal niet, en een ' 5 ' staat voor 'heel veel.

Administratieve ondersteuning

Ondersteunen en begeleiden van leerlingen

Overnemen van lessen

Extra begeleiding voor leerlingen met een achterstand

Surveillance- en pleinwachttaken

Anders, namelijk....
12345

12345

12345

12345

12345

12345

Bent u hier tevreden over deze rolverdeling?

\section{$\mathrm{Ja}$}

Nee

Licht kort toe.

A) Wordt er binnen de school door u of uw collega's (samen)gewerkt met academische leraren?

\section{$\mathrm{Ja}$}

Nee

B) (Verschijnt alleen indien 'ja' is ingevuld bij 4a) In welke mate voeren de academische leraren binnen uw school de volgende taken uit? Kruis aan wat van toepassing is, waarbij een ' 1 ' staat voor 'helemaal niet, en een ' 5 ' staat voor 'heel veel.

Curriculum: schoolbreed ontwikkelen of kiezen curriculum/methoden/toetsen

C) DROPDOWN PER ROL: In welke mate zou u wensen dat academische leraren deze taken uitvoeren? Kruis aan wat van toepassing is, waarbij een ' 1 ' staat voor 'helemaal niet, en een ' 5 ' staat voor 'heel veel.

Curriculum: schoolbreed ontwikkelen of kiezen curriculum/methoden/toetsen Onderzoek: onderzoek in de school of voor de stichting

Beleid: meeschrijven van beleidsplan of schoolgids 


\section{Blok 3: Vragen over het teamgerichte personeelsbeleid}

Hieronder volgen enkele vragen over de mate waarin men binnen uw team elkaars sterke punten kent, erkent en gebruikt.

5.

In mijn team...

zorgen we ervoor dat de rollen van teamleden zijn afgestemd op hun sterke punten

richten we het werk zo in dat iedereen zijn/haar sterke punten toe kan passen

$\square$ verdelen we taken gebaseerd op de sterke punten van teamleden

$\square$ krijgt iedereen een unieke rol in het teamproces toebedeeld die aansluit bij zijn/haar sterke punten

$\square$ houden we rekening met de voorkeuren van teamleden bij het verdelen van taken

$\square$ organiseren we het werk zo dat de sterke punten van teamleden elkaar aanvullen

De vragen hieronder gaan over specifieke onderdelen van het personeelsbeleid binnen uw team. Kun u aangeven in hoeverre onderstaande kenmerken van teamgericht personeelsbeleid binnen uw school aanwezig zijn? Kruis aan wat van toepassing is, waarbij een ' 1 ' staat voor 'helemaal niet van toepassing', en een ' 5 ' staat voor 'heel erg van toepassing'.

6.

Bij de werving en selectie van nieuwe leden voor mijn team wordt rekening gehouden met:

De mate waarin zij zich willen inzetten voor het teambelang

De mate waarin zij een potentiële bijdragen kunnen leveren aan teamprestaties

Hun vaardigheid om in teamverband te werken

De mate waarin zij 'team players' zijn
12345

12345

12345

12345

7.

Mijn team krijgt ontwikkelmogelijkheden aangeboden die gericht zijn op...

De leerbehoefte van mijn team

Onderwerpen die mijn team nodig heeft om zich verder te kunnen professionaliseren 12345

Het versterken van de kwaliteiten van mijn team

12345

Het verhogen van de teamresultaten

12345

8.

Binnen mijn team wordt bij de waardering van mijn werk rekening gehouden met...

Mijn bijdrage aan teamprestaties.

De mate waarin ik initiatieven neem binnen het team.

Mijn bijdrage aan de professionalisering van het team.

Mijn bijdrage aan het goed functioneren van het team.
12345

12345

12345

12345 
Bij de waardering van mijn team als geheel wordt rekening gehouden met...

De prestaties van mijn team

De initiatieven die mijn team neemt

Hoe binnen het team gewerkt wordt aan professionalisering

De mate waarin het team goed functioneert
12345

12345

12345

12345

10.

Leden van mijn team beschikken over mogelijkheden om...

Nieuwe ideeën op te doen door deelname aan activiteiten, zoals werkgroepen, projectgroepen, informatiebijeenkomsten, etc.

12345

Contact te leggen/onderhouden met mensen buiten het team

12345

Ervaringen uit te wisselen met collega's buiten het team

12345

Mensen buiten het team om ideeën/expertise te vragen

12345

Gezamenlijk te werken aan onze teamtaken

12345

Bijeen te komen om het team-functioneren te bespreken

12345

Samen oplossingen te bedenken voor problemen/ uitdagingen

12345

Met elkaar vernieuwingen/aanpassingen door te voeren

12345

11.

Door wie of welk orgaan wordt op uw school besloten over de aanpak van de inzet van werkdrukmiddelen?

Door het team

Door de schoolleiding

Door de medezeggenschapsraad

Door het bestuur

Anders, namelijk:

Geen van dit

Weet ik niet

\section{Blok 4: Vragen over uw werkbeleving}

De volgende uitspraken hebben betrekking op hoe u uw werk beleeft en hoe u zich daarbij voelt. Kruis aan wat van toepassing is, waarbij een ' 0 ' staat voor 'nooit', en een ' 6 ' staat voor 'dagelijks'.

\section{Ervaren werkplezier}

Op mijn werk bruis ik van energie.

Als ik werk voel ik me fit en sterk.

Ik ben enthousiast over mijn baan.

Mijn werk inspireert mij.

Als ik 's morgens opsta heb ik zin om aan het werk te gaan.

Wanneer ik heel intensief aan het werk ben, voel ik mij gelukkig.

Ik ben trots op het werk dat ik doe.

Ik ga helemaal op in mijn werk.

Mijn werk brengt mij in vervoering.
0123456

0123456

0123456

0123456

0123456

0123456

0123456

0123456

0123456 


\section{Ervaren werkdruk}

Ik voel me mentaal uitgeput door mijn werk.

0123456

Aan het eind van een werkdag voel ik me leeg.

0123456

Ik voel me vermoeid als ik 's morgens opsta en er weer een werkdag voor me ligt.

0123456

De hele dag met mensen werken vormt een zware belasting voor mij.

0123456

Ik voel me "opgebrand" door mijn werk.

0123456

Ik voel me gefrustreerd door mijn baan.

0123456

Ik denk dat ik me teveel inzet voor mijn werk.

0123456

Ik voel me aan het einde van mijn Latijn.

0123456

\section{Specifiek voor Onderwijsassistenten: Vertrekintentie}

Ik wou dat ik een andere baan had dan het onderwijsassistentschap.

0123456

Als ik opnieuw mocht kiezen, zou ik geen onderwijsassistent zijn.

0123456

Ik denk er vaak over om het beroep te verlaten.

0123456

\section{Specifiek voor Leraren: Vertrekintentie}

Ik wou dat ik een andere baan had dan het leraarschap.

0123456

Als ik opnieuw mocht kiezen, zou ik geen leraar zijn.

0123456

Ik denk er vaak over om het lerarenberoep te verlaten.

0123456

Ten slotte hebben we nog twee open vragen voor $u$, over de werkdruk binnen uw team.

13.

Indien $\mathrm{u}$ als team werkdruk ervaart, wat heeft uw team dan nodig om werkdruk te verminderen?

\section{4.}

De vragen in deze vragenlijst werden vaak gesteld vanuit een teamperspectief. Bij het beantwoorden van de vragen vroegen we $u$ aan het begin van de vragenlijst de gang van zaken binnen uw schoolteam in gedachten te houden.

We realiseren ons dat teams per school anders georganiseerd zijn. Zo kan een team op de ene school de hele school beslaan, terwijl er op een andere school sprake is van onder- of bovenbouwteams, of weer anders georganiseerde teams.

Met de term 'team' doelen we in deze vraag op een groep mensen die een gezamenlijke verantwoordelijkheid heeft en/of onder personele verantwoordelijkheid van een en dezelfde teamleider valt (dit bijvoorbeeld een schoolleider, een locatieleider of een bouwcoördinator zijn).

Kunt $u$ een beschrijving geven (in max. 50 woorden) in welk team u binnen uw school nog meer, functioneert naast het gehele schoolteam? 


\section{Bijlage 5: Coderingtabel open vragen vragenlijststudie}

\begin{tabular}{|c|c|c|c|c|c|c|c|c|}
\hline Hoofd & Operationalisatie & $n$ & Subcode & Operationalisatie & $n$ & subcode & Operationalisatie & $n$ \\
\hline \multirow[t]{3}{*}{ Positief } & $\begin{array}{l}\text { Participant is positief over de } \\
\text { inzet van onderwijsassistenten: } \\
\text { 'Het is fijn dat er extra handen in } \\
\text { de school zijn' }\end{array}$ & 29 & $\begin{array}{l}\text { Gelijkwaardig } \\
\text { teamlid }\end{array}$ & $\begin{array}{l}\text { De onderwijsassistent wordt } \\
\text { gezien als gelijke en als } \\
\text { volwaardig lid van het team: } \\
\text { 'Ik ben net zozeer deel van het } \\
\text { team als iedereen' }\end{array}$ & 5 & & & \\
\hline & & & $\begin{array}{l}\text { Goede } \\
\text { samenwerking / } \\
\text { communicatie }\end{array}$ & $\begin{array}{l}\text { De samenwerking en } \\
\text { communicatie met de } \\
\text { onderwijsassistent loopt goed: } \\
\text { 'Heldere, open en fijne manier } \\
\text { van samenwerken' }\end{array}$ & 8 & & & \\
\hline & & & $\begin{array}{l}\text { Werkdrukverlicht } \\
\text { ing }\end{array}$ & $\begin{array}{l}\text { De onderwijsassistenten zorgen } \\
\text { voor een verminderde werkdruk: } \\
\text { 'Ze nemen ons veel werk uit } \\
\text { handen' }\end{array}$ & 6 & $\begin{array}{l}\text { Ondersteu } \\
\text { ning/ } \\
\text { extra } \\
\text { handen }\end{array}$ & $\begin{array}{l}\text { Doordat de onderwijsassistenten } \\
\text { extra ondersteunen kunnen } \\
\text { bieden, zorgen ze voor } \\
\text { werkdrukverlichting: } \\
\text { 'Fijn om ondersteuning te krijgen' }\end{array}$ & 10 \\
\hline \multirow[t]{2}{*}{ Negatief } & $\begin{array}{l}\text { Participant is negatief over de } \\
\text { inzet van onderwijsassistenten: } \\
\text { 'Het niveau van } \\
\text { onderwijsassistenten voldoet niet } \\
\text { aan de eisen van leerkrachten' }\end{array}$ & 42 & $\begin{array}{l}\text { Ondergewaardee } \\
\text { rd }\end{array}$ & $\begin{array}{l}\text { De onderwijsassistent wordt } \\
\text { ondergewaardeerd en wordt niet } \\
\text { als gelijke beschouwt: } \\
\text { 'Ik voel mij zeer } \\
\text { ondergewaardeerd door collega's' }\end{array}$ & 5 & $\begin{array}{l}\text { Ondergew } \\
\text { aardeerd } \\
\text { in salaris }\end{array}$ & $\begin{array}{l}\text { Onderwijsassistenten worden niet } \\
\text { betaald voor het werk dat zij } \\
\text { verrichten: } \\
\text { 'Helaas krijg ik niet betaald als } \\
\text { leraar ondersteuner, maar ik voer } \\
\text { wel die werkzaamheden uit' }\end{array}$ & 8 \\
\hline & & & $\begin{array}{l}\text { Behoefte aan } \\
\text { betere } \\
\text { communicatie }\end{array}$ & $\begin{array}{l}\text { Er wordt onvoldoende helder met } \\
\text { de onderwijsassistenten } \\
\text { gecommuniceerd over } \\
\text { verwachtingen: } \\
\text { 'Er wordt vaak voor mij beslist. } \\
\text { Ik zou graag meer inspraak } \\
\text { hebben over mijn taken' }\end{array}$ & 5 & & & \\
\hline
\end{tabular}




\begin{tabular}{|c|c|c|c|c|c|c|c|c|}
\hline Hoofdcode & Operationalisatie & $n$ & Subcode & Operationalisatie & $n$ & subcode & Operationalisatie & $n$ \\
\hline \multirow[t]{2}{*}{$\begin{array}{l}\text { Externe } \\
\text { mogelijkhed } \\
\text { en }\end{array}$} & $\begin{array}{l}\text { Werkdrukverlichting wordt } \\
\text { gevonden in externe middelen: } \\
\text { 'Meer handen in de klas' }\end{array}$ & 26 & Meer handen & $\begin{array}{l}\text { De inzet van meer personeel ter } \\
\text { verlichting van de werkdruk: } \\
\text { 'Meer personeel' }\end{array}$ & 12 & $\begin{array}{l}\text { Onderwijs } \\
\text { assistente } \\
\mathrm{n}\end{array}$ & $\begin{array}{l}\text { Verhoogde inzet van } \\
\text { onderwijsassistenten: } \\
\text { 'Een onderwijsassistent per } \\
\text { groep' }\end{array}$ & 13 \\
\hline & & & & & & $\begin{array}{l}\text { Vakleerkra } \\
\text { chten }\end{array}$ & $\begin{array}{l}\text { Verhoogde inzet van } \\
\text { vakleerkrachten: } \\
\text { 'Vakleerkrachten die lessen over } \\
\text { kunnen nemen' }\end{array}$ & 1 \\
\hline \multirow[t]{3}{*}{$\begin{array}{l}\text { Schoolorgan } \\
\text { isatie }\end{array}$} & $\begin{array}{l}\text { Oplossingen voor de werkdruk } \\
\text { worden aangedragen binnen de } \\
\text { schoolorganisatie: } \\
\text { 'Niet onderwijs gerelateerde } \\
\text { taken dienen niet bij leerkrachten } \\
\text { terecht te komen' }\end{array}$ & 28 & Meer tijd & $\begin{array}{l}\text { Meer tijd voor andere } \\
\text { verplichtingen binnen school: } \\
\text { 'Meer tijd om bij te werken' }\end{array}$ & 13 & & & \\
\hline & & & $\begin{array}{l}\text { Minder } \\
\text { zorgleerlingen }\end{array}$ & $\begin{array}{l}\text { Minder zorgleerlingen per klas of } \\
\text { meer tijd om deze te begeleiden: } \\
\text { 'Meer hulp om kinderen met } \\
\text { speciale behoeften te begeleiden' }\end{array}$ & 3 & & & \\
\hline & & & $\begin{array}{l}\text { Minder } \\
\text { administratie }\end{array}$ & $\begin{array}{l}\text { Behoefte aan minder } \\
\text { administratieve taken: } \\
\text { 'minder administratieve } \\
\text { bezigheden of hulp erbij' }\end{array}$ & 12 & & & \\
\hline
\end{tabular}




\begin{tabular}{|c|c|c|c|c|c|c|c|c|}
\hline Hoofdcode & Operationalisatie & $n$ & Subcode & Operationalisatie & $n$ & Subcode & Operationalisatie & $n$ \\
\hline \multirow[t]{4}{*}{$\begin{array}{l}\text { Inzet } \\
\text { personeel }\end{array}$} & $\begin{array}{l}\text { Werkdrukverlichting kan worden } \\
\text { gezocht in de manier waarop het } \\
\text { personeel wordt ingezet: } \\
\text { 'de juiste mensen op de juiste } \\
\text { plek zetten' }\end{array}$ & 19 & Goede afspraken & $\begin{array}{l}\text { Er kan verbeterd worden in } \\
\text { communicatie en helderheid van } \\
\text { afspraken: } \\
\text { 'Meer duidelijkheid van taken' }\end{array}$ & 6 & & & \\
\hline & & & Duidelijke leider & $\begin{array}{l}\text { Behoefte aan een duidelijke en } \\
\text { daadkrachtige leider: } \\
\text { 'een daadkrachtige } \\
\text { leidinggevende' }\end{array}$ & 5 & & & \\
\hline & & & $\begin{array}{l}\text { Meer gebruik } \\
\text { van elkaars } \\
\text { kwaliteiten }\end{array}$ & $\begin{array}{l}\text { Het team optimaal benutten } \\
\text { door elkaars kwaliteiten te } \\
\text { gebruiken: } \\
\text { 'meer inzet op kwaliteiten en } \\
\text { interesses van individuele } \\
\text { leerkrachten' }\end{array}$ & 4 & & & \\
\hline & & & Meer autonomie & $\begin{array}{l}\text { Meer vrijheid om eigen keuzes te } \\
\text { maken: } \\
\text { 'Rust om het zelf in te delen' }\end{array}$ & 4 & & & \\
\hline Positief & $\begin{array}{l}\text { Geen sprake van behoefte aan } \\
\text { werkdrukverlichting: } \\
\text { 'In mijn team gaat dit goed' }\end{array}$ & 4 & & & & & & \\
\hline Restcategorie & $\begin{array}{l}\text { Neutrale reactie die niet te } \\
\text { schalen zijn in een categorie: } \\
\text { 'licht, lucht en liefde' }\end{array}$ & 3 & & & & & & \\
\hline
\end{tabular}




\section{2 schoolleiders}

\begin{tabular}{|l}
\hline Het doel van de toolkit: is \\
je gelijk (of na een kort \\
bezoek aan de toolkit) \\
duidelijk waarvoor deze \\
dient en wat je er kunt
\end{tabular}

'halen'?
Leraren

Leraar 2

De welkompagina is

duidelijk, en deze is

cruciaal om te weten

wat de toolkit kan

brengen. Maar toen we

de manometer invulden

hadden we eigenlijk

continu weer de

behoefte hierop terug te

grijpen: waarom vullen

we dit in? Dus

misschien is het slim

om ook in de

manometer, bovenaan

de indicatoren dit doel

te herhalen.

Misschien kunnen jullie je in dit welkomstwoord nog richten op

schoolleiders die vanuit

het bovenliggend

bestuur een opdracht

meekrijgen t.a.v.

anders organiseren?

Voor hen zou de toolkit

namelijk erg van

waarde kunnen zijn om

erachter te komen 'wat

eraan schort'.

\section{Leraar 1}

$\mathrm{Na}$ het lezen van de

werkwijze was het doel

duidelijk. Ik wist wat ik ging

doen en waarom.
Het eerst wat ik me

afvraag: waar staat MANO

(van manometer) voor?

Het is een instrument om drukverschil te meten,

maar ik begrijp de link met de toolkit niet helemaal. De naam spreekt niet voor zich dus dan is het niet meteen duidelijk wat ik ermee kan. Omdat ik niet meer terug kan naar de 'welkom' pagina, kan ik verder deze vraag niet volledig beantwoorden.

Het is in de toolkit en ook bij de manometer mijns inziens belangrijk dat je de juiste persoon aanspreekt. Voor leraren kun je het best focussen op

taakdifferentiatie tussen leraren en daar dan ook de stellingen op aanpassen.

Voor onderwijsassistenten kun je specifiek naar hun mening over hun inzet vragen. Zij kunnen niet alle stellingen voor bv leraren beoordelen. De schoolleider kun je vragen naar zijn oordeel over beide groepen. Ik zal hier vrijdag nog even een
Onderwijsassistent

Leraar 3 (met onderwijsassistent-

Waarom de toolkit is

ontwikkeld, is wel duidelijk. Maar ik zie niet goed wat ik er zelf uit kan halen.

Waarschijnlijk heb je er meer aan als je het met het hele team invult. Dan kun je veel concreter kunt bepalen waar je aandachtspunten

liggen en waar je aan kunt werken.

Individueel heb ik er niet zoveel aan, maar als team wel. ALS je 'm alleen invult, dan moet je daarna ook de koppeling maken met het

team. Want als je iets aan de werkdruk wilt doen, dan moet je daarvoor ok bij het team zijn. Ook als een individu werkdruk voelt en de rest van het team minder. Je moet elkaar

hierbij ondersteunen, dus je komt altijd uit bij het gehele team.

\section{Het doel is mij we}

duidelijk, al moest ik we even zoeken hoe de opbouw van de toolkit in elkaar steekt. Hier was ik redelijk snel achter. Wellicht dit nog iets overzichtelijker maken voor de bezoeker. 


\begin{tabular}{|c|c|c|c|c|c|}
\hline & & & $\begin{array}{l}\text { voorbeeld van geven. } \\
\text { Spreek je ze met 'je' of 'u' } \\
\text { aan? } \\
\text { Je maakt dus eigenlijk drie } \\
\text { tools die vergelijkbaar zijn } \\
\text { qua inhoud maar net een } \\
\text { andere focus hebben. Dan } \\
\text { heb je m.i. een veel } \\
\text { valider beeld van de } \\
\text { percepties van de } \\
\text { professionals. } \\
\text { Formulering van de } \\
\text { vragen. Vraagstelling nu te } \\
\text { veel diversiteit in } \\
\text { antwoorden creëert. }\end{array}$ & & \\
\hline $\begin{array}{l}\text { Hoe ervaar je de inrichting } \\
\text { van de toolkit, en dan met } \\
\text { name: } \\
\text { De tabbladen (bovenaan) } \\
\text { en de volgorde daarvan } \\
\text { De informatie die gegeven } \\
\text { wordt (is dit de informatie } \\
\text { die je ook zou } \\
\text { verwachten?) } \\
\text { De gebruiksvriendelijkheid } \\
\text { van de gehele toolkit (kun } \\
\text { je er goed doorheen } \\
\text { navigeren?) }\end{array}$ & $\begin{array}{l}\text { De tabbladen werken } \\
\text { nog niet allemaal. De } \\
\text { leesbaarheid is prima } \\
\text { en de toon van de } \\
\text { teksten ook. De teksten } \\
\text { zijn goed leesbaar en } \\
\text { met name de links naar } \\
\text { literatuur zijn erg } \\
\text { waardevol. Deze doen } \\
\text { het nog niet allemaal, } \\
\text { maar hier zijn we heel } \\
\text { nieuwsgierig naar. }\end{array}$ & $\begin{array}{l}\text { Het navigeert heel duidelijk. } \\
\text { De toolkit maakt goed } \\
\text { zichtbaar waar je aan kunt } \\
\text { werken samen. } \\
\text { Tabblad 'account' zou ik } \\
\text { helemaal naar rechts } \\
\text { plaatsen. Tabblad } \\
\text { 'werkwijze' zou ik dan als } \\
\text { tweede plaatsen en } \\
\text { 'achtergrond' daarna pas. } \\
\text { Tabblad werkwijze is verder } \\
\text { duidelijk, maar tabblad } \\
\text { 'achtergrondinformatie' is } \\
\text { saai. Het taalgebruik is hier } \\
\text { wollig (lange zinnen), en er } \\
\text { staat veel tekst, en ook veel } \\
\text { links. Na alinea } 1 \text { was je mij } \\
\text { al kwijt. } \\
\text { Tabblad achtergrond mag } \\
\text { dus veel aantrekkelijker. Ik } \\
\text { raad aan kleur te } \\
\text { gebruiken, illustraties toe te }\end{array}$ & $\begin{array}{l}\text { Tabbladen: } \\
\text { Ik zou 'account' aan het } \\
\text { eind zetten. De rest van de } \\
\text { volgorde is goed. Ik zou } \\
\text { ook een tabblad "goede } \\
\text { voorbeelden" toevoegen. } \\
\text { Dit is m.i. een heel } \\
\text { belangrijk onderdeel en } \\
\text { staat nu telkens onderaan } \\
\text { de pagina's. Bij het } \\
\text { toevoegen van goede } \\
\text { voorbeelden zou ik wel } \\
\text { heel duidelijke criteria } \\
\text { hanteren. Waarom zijn dat } \\
\text { in jullie ogen goede } \\
\text { voorbeelden? Hoe } \\
\text { selecteer je die? } \\
\text { Informatie: } \\
\text { Fijn dat er veel } \\
\text { achtergrondinformatie } \\
\text { beschikbaar is en dat er } \\
\text { ook duidelijke links naar }\end{array}$ & $\begin{array}{l}\text { Tabbladen als geheel en de } \\
\text { volgorde: goed en duidelijk. } \\
\text { !! kan niet terug naar } \\
\text { welkom als je de } \\
\text { manometer hebt ingevuld, } \\
\text { maar als je vanaf een } \\
\text { andere browser opent, lukt } \\
\text { dit ook. } \\
\text { Informatie was duidelijk en } \\
\text { de achtergrond was nuttig. } \\
\text { 'Welkom' is niet te lang, dat } \\
\text { is heel fijn. } \\
\text { Toon van de teksten was } \\
\text { duidelijk en persoonlijk. Niet } \\
\text { te formeel, maar juist } \\
\text { menselijk. } \\
\text { Navigeren: het is } \\
\text { verwarrend dat je binnen } \\
\text { tabblad 'Manometer' niet } \\
\text { gelijk bij de daadwerkelijke } \\
\text { manometer komt. De toolkit }\end{array}$ & $\begin{array}{l}\text { Over de inrichting van de } \\
\text { toolkit; Qua navigatie is het } \\
\text { af en toe wel even zoeken. } \\
\text { Als je op een pagina bent en } \\
\text { je wilt terug naar de vorige } \\
\text { informatie dan klik je niet } \\
\text { heel gemakkelijk even op } \\
\text { een link terug naar de } \\
\text { eerder bekeken pagina maar } \\
\text { moet je helemaal terug via } \\
\text { de ander pagina's. Daar ook } \\
\text { een stukje overzicht dat } \\
\text { ontbreekt. } \\
\text { Nog een puntje is dat bij de } \\
\text { categorie: 'faciliteren } \\
\text { teamwerk en dan de } \\
\text { subcategorie': koppeling } \\
\text { tussen onderwijskundige } \\
\text { visie en teambeleid, deze er } \\
2 \text { keer staat onder elkaar. }\end{array}$ \\
\hline
\end{tabular}

Bijlage 6: Feedback expertpanel toolkit | 76 


\begin{tabular}{|c|c|c|c|c|c|}
\hline & & $\begin{array}{l}\text { voegen, lange zinnen eruit } \\
\text { te filteren, wellicht filmpjes } \\
\text { gebruiken ter vervanging } \\
\text { voor tekst. } \\
\text { Gebruiksvriendelijkheid van } \\
\text { de toolkit als geheel is } \\
\text { prima. Je gaat er heel } \\
\text { soepel en gemakkelijk } \\
\text { doorheen. }\end{array}$ & $\begin{array}{l}\text { het onderzoek bij zitten } \\
\text { (de links werken niet, } \\
\text { maar daar wordt } \\
\text { waarschijnlijk aan } \\
\text { gewerkt). De teksten zijn } \\
\text { niet te lang of te complex } \\
\text { (nog wel veel schrijf en } \\
\text { spelfouten, maar daar } \\
\text { wordt aan gewerkt). } \\
\text { Gebruiksvriendelijkheid: } \\
\text { Los van het feit dat ik niet } \\
\text { terug kan naar de welkom- } \\
\text { pagina, is het goed } \\
\text { navigeren. Als ik op de } \\
\text { pagina van manometer zit, } \\
\text { dan kan ik de pijltjes links } \\
\text { op de pagina niet } \\
\text { gebruiken. De SHRM } \\
\text { pagina moet nog gevuld } \\
\text { worden. Soms staat links } \\
\text { voluit geschreven (bij bv. } \\
\text { achtergrond). Ik zou hier } \\
\text { hyperlinks van maken en } \\
\text { ze achter een tekst zetten. }\end{array}$ & $\begin{array}{l}\text { verspringt gelijk naar } \\
\text { Account, maar op dat } \\
\text { moment is het nog niet } \\
\text { duidelijk waarom. Misschien } \\
\text { onder "manometer" } \\
\text { woordelijk beschrijven: nog } \\
\text { geen account? Ga dan } \\
\text { naar... }\end{array}$ & $\begin{array}{l}\text { Als laatste tot zover: bij het } \\
\text { kopje Manometer staat } \\
\text { aangegeven wie er een } \\
\text { account kunnen of mogen } \\
\text { aanmaken. Nu heb ik dit } \\
\text { gewoon als onderwijsassist } \\
\text { geprobeerd en dat lukt } \\
\text { prima. Dit bracht me even in } \\
\text { verwarring aangezien het } \\
\text { me nu niet helemaal } \\
\text { duidelijk is, wie de account } \\
\text { mag aanmaken en wie de } \\
\text { Manometer mag invullen. } \\
\text { Ik heb de Manometer } \\
\text { ingevuld bij het kopje } \\
\text { onderwijsassisten omdat ik } \\
\text { daar momenteel het meeste } \\
\text { in zit en veel over kan } \\
\text { vertellen. Ik durf zo } 123 \\
\text { niet te zeggen in hoeverre ik } \\
\text { de andere onderwerpen/ } \\
\text { vragen goed kan } \\
\text { beantwoorden. }\end{array}$ \\
\hline $\begin{array}{l}\text { Zou je de manometer zelf } \\
\text { ook willen invullen om te } \\
\text { checken: } \\
\text { of je het gevoel hebt op elk } \\
\text { aspect een passend } \\
\text { antwoord te kunnen geven } \\
\text { of je de manometer zelf } \\
\text { gebruiksvriendelijk vindt } \\
\text { of je het idee hebt met de } \\
\text { informatie die er staat } \\
\text { verder te kunnen? }\end{array}$ & $\begin{array}{l}\text { De manometer is } \\
\text { gebruiksvriendelijk, en } \\
\text { we kunnen er veel } \\
\text { relevante informatie } \\
\text { vinden. Althans, we } \\
\text { schatten in dat er in de } \\
\text { toekomst komt te } \\
\text { staan. } \\
\text { Misschien is het slim } \\
\text { om, wanneer iemand } \\
\text { rood of oranje invult op } \\
\text { een vraag, gelijk een } \\
\text { literatuurtip te geven, } \\
\text { of een link naar waar }\end{array}$ & $\begin{array}{l}\text { Als je je registreert, wordt } \\
\text { gevraagd om de locatie van } \\
\text { je school. Ik vroeg me toen } \\
\text { af: welke informatie willen } \\
\text { ze hier van mij weten? } \\
\text { Gebruiksvriendelijkheid: Ik } \\
\text { vond het verwarrend dat er } \\
\text { staat dat je je gegevens } \\
\text { tussendoor kunt opslaan. In } \\
\text { mijn optiek doe je dit } \\
\text { gewoon in 1x. Je gaat er } \\
\text { even voor zitten. Waarom is } \\
\text { tussentijds opslaan dan } \\
\text { nodig? }\end{array}$ & $\begin{array}{l}\text { "Geef de situatie binnen uw } \\
\text { team een score" } \\
\text { Een score doet mij denken } \\
\text { aan } 1-2-3-4 \text {. Misschien } \\
\text { beter veranderen in } \\
\text { 'oordeel'. } \\
\text { Misschien positiever als } \\
\text { "op orde" bovenaan komt } \\
\text { te staan? Dan is het gelijk } \\
\text { met wat er aan de } \\
\text { linkerkant van de pagina } \\
\text { staat. } \\
\text { Waar kan ik de ingevulde } \\
\text { opmerkingen bekijken? Die }\end{array}$ & $\begin{array}{l}\text { Op orde/twijfel/niet op orde. } \\
\text { Maar het kan ook zijn dat je } \\
\text { ermee bezig bent. Dan kan } \\
\text { het ook zijn 'het is in } \\
\text { ontwikkeling'. } \\
\text { Tussenoptie is fijn. } \\
\text { In het begin wel even } \\
\text { zoeken, maar als je het } \\
\text { eenmaal door hebt, dan } \\
\text { werkt het perfect. Misschien } \\
\text { ergens aan het begin } \\
\text { plaatsen "vul je antwoord } \\
\text { rechts in'. }\end{array}$ & \\
\hline
\end{tabular}




\begin{tabular}{|c|c|c|c|c|c|}
\hline & $\begin{array}{l}\text { men meer informatie } \\
\text { kan vinden over het een } \\
\text { of ander. }\end{array}$ & $\begin{array}{l}\text { Daarnaast was het niet } \\
\text { helemaal duidelijk dat je na } \\
\text { het invullen actief op het } \\
\text { pijltje moet klikken (want er } \\
\text { staat 'uw antwoorden } \\
\text { worden automatisch } \\
\text { opgeslagen'). Rondjes } \\
\text { groter maken, meer in het } \\
\text { zicht?? } \\
\text { Nog niet helemaal duidelijk } \\
\text { wat gebeurt nadat je de } \\
\text { laatste vraag hebt ingevuld. } \\
\text { "U bent klaar", mist. } \\
\text { Woordkeuze manometer en } \\
\text { kleurtjes heel goed } \\
\text { gevonden. Werkt prettig. }\end{array}$ & $\begin{array}{l}\text { kan ik nergens meer } \\
\text { terugvinden. } \\
\text { De pijltjes links werken } \\
\text { niet. De pijltjes rechts vind } \\
\text { ik wat onduidelijk (ik } \\
\text { kwam er pas later achter } \\
\text { dat ik die kon gebruiken, } \\
\text { misschien bovenaan de } \\
\text { pagina zetten?). Die } \\
\text { pijltjes werken overigens } \\
\text { wel. } \\
\text { Je kunt de manometer } \\
\text { meerdere keren invullen, } \\
\text { klopt dat? Wat is hiervan } \\
\text { het doel? Kun je bepaalde } \\
\text { ingevulde lijsten later } \\
\text { wel/niet koppelen aan } \\
\text { elkaar? } \\
\text { Er moet nog grondig door } \\
\text { de teksten worden gegaan } \\
\text { (qua spelfouten en } \\
\text { formuleringen). Want hier } \\
\text { is nog veel ruimte voor } \\
\text { verbetering;) Ik heb hier } \\
\text { nu geen feedback op } \\
\text { gegeven, maar ik zou dit } \\
\text { nog goed doornemen. }\end{array}$ & $\begin{array}{l}\text { Suggestie: op tabblad } \\
\text { welkom manometer, links de } \\
\text { structuur met indicatoren } \\
\text { plaatsen, zodat de layout in } \\
\text { de manometer hetzelfde is. } \\
\text { Nu komt deze wat uit het } \\
\text { niets. } \\
\text { Op z'n minst tekst bovenaan } \\
\text { indicator om lezer te helpen } \\
\text { navigeren. }\end{array}$ & \\
\hline $\begin{array}{l}\text { In welke mate zou de } \\
\text { manometer jullie op gang } \\
\text { kunnen helpen, denk je? } \\
\text { Wat werkt goed? En/of } \\
\text { wat mis je nog? }\end{array}$ & $\begin{array}{l}\text { De toolkit is vooral van } \\
\text { meerwaarde als je deze } \\
\text { met het gehele team } \\
\text { invult. Minder om dit in } \\
\text { je eentje te doen. We } \\
\text { zouden juist graag } \\
\text { willen zien hoe iedereen } \\
\text { hier ten opzichte van } \\
\text { elkaar tegenaan kijkt. } \\
\text { Dat het iets is dat je }\end{array}$ & $\begin{array}{l}\text { Ik denk dat het goed zou } \\
\text { zijn voor ons en dat } \\
\text { iedereen op zich achter het } \\
\text { idee zou staan. Maar je } \\
\text { moet veel meer delen met } \\
\text { elkaar. Daar moet je wel } \\
\text { voor openstaan. } \\
\text { Ik denk dat er bij ons veel } \\
\text { weerstand is tegen het } \\
\text { gevoel dat je controle van }\end{array}$ & $\begin{array}{l}\text { Deze toolkit is bedoeld om } \\
\text { percepties van } \\
\text { taakdifferentiatie te } \\
\text { verzamelen van } \\
\text { professionals. Dit is enkel } \\
\text { en alleen data. Om deze } \\
\text { data om te zetten in } \\
\text { waardevolle informatie } \\
\text { voor de } \\
\text { onderwijsorganisatie, deze }\end{array}$ & $\begin{array}{l}\text { Ik denk het wel. Je krijgt } \\
\text { een completer beeld als } \\
\text { iedereen 'm heeft ingevuld. } \\
\text { Dan wordt mooi duidelijk } \\
\text { waar de aandachtpunten } \\
\text { liggen en wat er veranderd } \\
\text { moet worden. }\end{array}$ & \\
\hline
\end{tabular}


gezamenlijk kunt

invullen, mag wat ons

betreft meer benadrukt

worden.

Maar om er echt mee

aan de slag te kunnen

is meer nodig dan

alleen het invullen van

de scan. En dat laatste

stapje mist nu nog in de

toolkit. We vroegen ons

steeds af: hoe nu

verder?

Misschien helpt het om hier suggesties voor te geven, voorbeelden toe te voegen of een idee te geven van welke

vervolgstappen je kunt zetten. Partijen die

hierin iets kunnen

betekenen? We houden

ons aanbevolen! iets dat er met jouw klas gebeurt, uit handen geeft (bijv. als een collega een les komt geven aan jouw klas). informatie vervolgens te analyseren, interpreteren en te accepteren en het daarna ook nog te benutten t.b.v. het onderwijsteam is meer nodig dan alleen een toolkit.

Wat er in onderwijsteams nodig is, is iemand die kennis heeft van SHRM, werkgeluk, professioneel kapitaal etc. die het proces van databenutting in gang kan zetten en

veranderingen duurzaam kan verankeren in de organisatie. Eigenlijk een soort HR-medewerker op schoolniveau, die alle leerkrachten goed in beeld heeft. Er is een nieuwe opleiding die hier bij aansluit:

https://www. marnixacade mie. $\mathrm{nl} /$ master-vitaliteit-

professionaliteit. Een soort rechterhand van de

schoolleider. Uit eigen

ervaring, maar ook uit het algemene beeld van het onderwijs blijkt dat

schoolleiders zelf niet de juiste expertise hebben, of te druk zijn om dergelijke vraagstukken GOED op te lossen. 


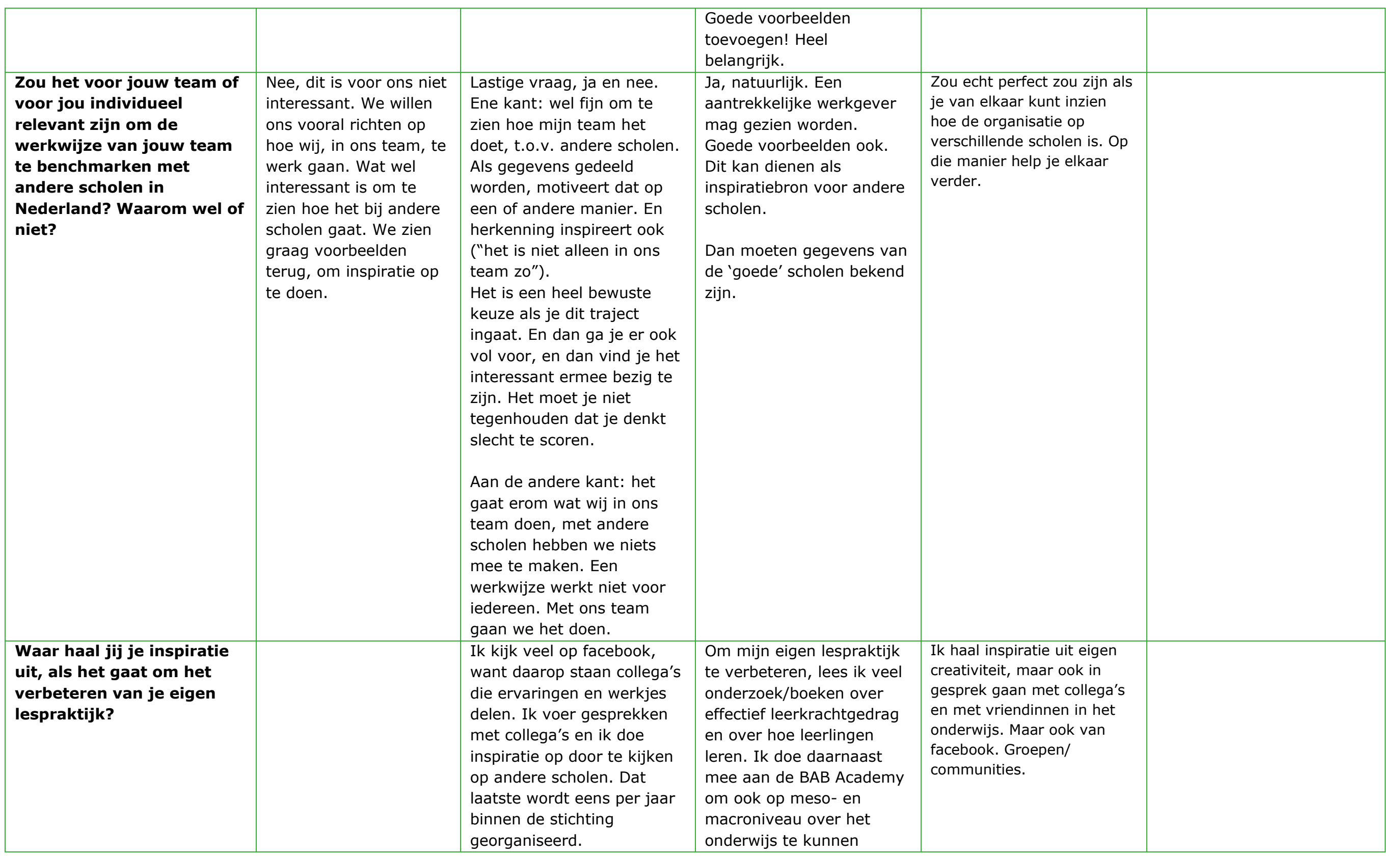




\begin{tabular}{|c|c|c|c|}
\hline & $\begin{array}{l}\text { Ik probeer de situaties van } \\
\text { leerlingen aan te grijpen om } \\
\text { te ontwikkelen. Maar dit is } \\
\text { wel gekleurd, we hebben } \\
\text { allemaal blinde vlekken. En } \\
\text { juist daarvoor is het goed } \\
\text { om bij elkaar te kijken. }\end{array}$ & $\begin{array}{l}\text { praten met gelijkopgeleide } \\
\text { leerkrachten. } \\
\text { Vanuit mijn rol als } \\
\text { onderzoeker bezoek ik } \\
\text { graag (inter)nationale } \\
\text { onderwijsconferenties. }\end{array}$ & \\
\hline Overig & $\begin{array}{l}\text { Ik zie een fout in zin: 'ok } \\
\text { hebben voor' ipv 'oog } \\
\text { hebben voor'. Tabblad } \\
\text { 'Manometer > faciliteren } \\
\text { van teamwerk' } \\
\text { Het resultaat van het team, } \\
\text { dat is de meerwaarde. Kun } \\
\text { je ook onderverdelen in } \\
\text { bouwteams? Ik werk het } \\
\text { meest samen met collega's } \\
\text { binnen het bouwteam, maar } \\
\text { ik wil óók zien hoe het hele } \\
\text { schoolteam scoort. } \\
\text { Uiteindelijk zinvol om te } \\
\text { weten wie uit welk subteam } \\
\text { welke score geeft. } \\
\text { Komt er dan nog ergens op } \\
\text { de pagina informatie van } \\
\text { hoe je dat als team verder } \\
\text { aan kunt pakken? } \\
\text { Vervolgstap mist nog. Wat } \\
\text { nu? Meer voorbeelden, } \\
\text { altijd fijn. Linkjes, filmpjes. } \\
\text { Succesverhalen } \\
\text { horen/lezen/zien is juist } \\
\text { fijn. } \\
\text { Jezelf kwetsbaar durven } \\
\text { opstellen en elkaar } \\
\text { feedback geven is cruciaal. }\end{array}$ & $\begin{array}{l}\text { Ik zou bij alles beginnen } \\
\text { met taakdifferentiatie en } \\
\text { daarna de inzet van } \\
\text { onderwijsassistenten } \\
\text { noemen. } \\
\text { Ik kan niet meer terug } \\
\text { naar de knop "welkom" } \\
\text { dus vandaar dat ik die } \\
\text { tekst niet kan lezen. } \\
\text { Check de hyperlinks nog } \\
\text { even, lang niet alle werken } \\
\text { (maar dat was je je } \\
\text { wellicht ook al bewust) } \\
\text { Zoeken jullie nog } \\
\text { voorbeelden uit de } \\
\text { praktijk? Via de BAB kan ik } \\
\text { wel contacten leggen als } \\
\text { dat nodig is. }\end{array}$ & $\begin{array}{l}\text { Ik heb naast deze } \\
\text { aandachtspunten ook veel } \\
\text { goede en nuttige punten } \\
\text { voorbij zien komen. Het is } \\
\text { zeker een interessante app } \\
\text { met wel veel informatie. }\end{array}$ \\
\hline
\end{tabular}


Maar hoe begeleid je dit nu?

links voor begeleiding

hiervoor ergens plaatsen.

Misschien kunnen jullie

voorbeelden toevoegen van

scholen door filmpjes te

plaatsen waarin zij vertellen

over hun werkwijze? Laat

leraren zelf aan het woord! 